Discussion Paper No. 18-044

\title{
Police Reorganization and Crime: Evidence from Police Station Closures
}

Sebastian Blesse and André Diegmann

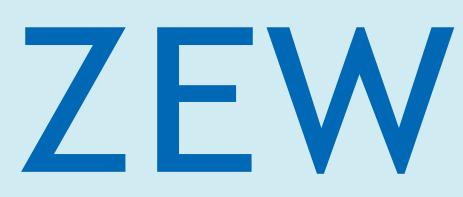

Zentrum für Europäische Wirtschaftsforschung $\mathrm{GmbH}$

Centre for European

Economic Research 
Discussion Paper No. 18-044

\section{Police Reorganization and Crime: Evidence from Police Station Closures}

Sebastian Blesse and André Diegmann

Download this ZEW Discussion Paper from our ftp server:

http://ftp.zew.de/pub/zew-docs/dp/dp18044.pdf

Die Discussion Papers dienen einer möglichst schnellen Verbreitung von neueren Forschungsarbeiten des ZEW. Die Beiträge liegen in alleiniger Verantwortung der Autoren und stellen nicht notwendigerweise die Meinung des ZEW dar.

Discussion Papers are intended to make results of ZEW research promptly available to other economists in order to encourage discussion and suggestions for revisions. The authors are solely responsible for the contents which do not necessarily represent the opinion of the ZEW. 


\title{
Police reorganization and crime: Evidence from police station closures
}

\author{
Sebastian Blesse ${ }^{\dagger}$ and André Diegmann ${ }^{\ddagger}$ \\ $\dagger$ ZEW Mannheim* \\ $\ddagger$ German Council of Economic Experts
}

October 2018

\begin{abstract}
Policy makers often try to optimize local law enforcement by reorganizing police forces. We study the effects of police reallocation via station closures on municipal crime by exploiting a quasi-experiment where a centrally administered reform substantially reduced the number of police stations. Combining a matching strategy with an event-study design, we do not find aggregate effects on crime. Instead, we find changes in the way theft is committed. We observe increases in car theft, apartment and basement burglary but less bicycle theft. We argue that station closures provide an opportunity for criminals to shift from low-value to high-value theft.
\end{abstract}

JEL Classification: K42, R53

Keywords: Crime, Deterrence, Police Centralization, Efficiency of Law Enforcement

\footnotetext{
*Full address of correspondence: Sebastian Blesse, Centre for European Economic Research, Department of Corporate Taxation and Public Finance, L 7.1, D-68161 Mannheim, Email: blesse@ zew.de; André Diegmann, German Council of Economic Experts, Gustav-Stresemann-Ring 11, D-65189 Wiesbaden, EMail: andre.diegmann@ outlook.com. We are grateful for the collaboration with the State Criminal Office in Baden-Wuerttemberg and of the Ministry of Interior in Baden-Wuerttemberg, and, in particular, of Friedemann Stolz and Timo Brenner, in this project. We welcome helpful comments by participants of the Spring Meeting of Young economists in Palma de Mallorca, the Hecer Seminar at Aalto University as well as Kriistina Huttunen, Janne Tukiainen, Tuukka Saarimaa, Martti Kaila, Thushyanthan Baskaran, Fabian Delos, Ulrich Zierahn, Felix Rösel, Christian Usalla, Martin Lange, Katrin Sommerfeld and Annika Havlik. We also thank Ozan Emre Akbas, Cenchen Liu, Marcel Wieting, Kathrin Dahlke, Magdalena Meissner, Sarah Coyne and Vibeke Müller for excellent research assistance. The views expressed in this paper represent the authors' personal opinions and do not necessarily reflect the views German Council of Economic Experts.
} 


\section{Introduction}

Combating crime in times of tight public budgets is a key concern for politicians in developed countries. Policy makers frequently reorganize of police forces for more efficiency in law enforcement (Fyfe et al., 2013; Mendel et al., 2017), often resulting in a centralization of policing and a reduction in the number of local police stations ${ }_{12}^{12}$ Mergers of police stations are a common tool in the hope to improve efficiency in law enforcement and to tackle rising expenditures for policing as well as for public safety ${ }_{3}^{3}$

While there is some evidence that larger police stations lead to lower costs of policing (Simper and Weyman-Jones, 2008; Maher, 2015), less is known about the crime effects of police mergers. This paper fills this gap in the literature and provides novel quasiexperimental evidence on the crime effects of a large scale police station merger reform in Germany which resulted in the closure of about $40 \%$ of local police stations.

Shutting down local police stations through mergers can affect crime in various ways. It may have negative effects on crime through increased distances to nearby stations. Thus, access of citizens to police services is reduced but also travel distance of local police officers increases in case of crime notification. Moreover, criminals may find it less costly to engage in criminal activities as station closures likely lead to lower presence of police forces. Thus, criminals could feel less threatened to be punished. Local law enforcement may also be less efficient in closure municipalities due to longer driving distances. However, local forces may be more efficient if closures of small and less productive stations leads to larger and more professional police services. Hence, the effects of police station closures on crime and the underlying channels at work are ultimately an empirical question.

In this paper, we provide new evidence on local crime effects of police station mergers in a quasi-experimental set-up. For this, we study the impact of local police station closures in Germany in the period 1996-2011 on various crime outcomes including the number of reported crimes, detection rates and monetary values of committed crimes at

\footnotetext{
${ }^{1}$ For instance, consolidation waves of police stations led to substantial shut-downs of local stations in the UK (Metropolitan Police, 2016), Switzerland (Aargauer Zeitung, 2017), Belgium (Vereniging van Vlaamse Steden en Gemeenten, 2017), New Zealand (New Zealand Parliament, 2017), Finland (Haraholma and Houtsonen, 2013), Austria (Bundesministerium für Inneres, 2014), Denmark, Scotland, the Netherlands (Mendel et al., 2017) and Germany (this study) as well as in the US. The US department of Justice reports , for example, the shut-down of 175 (1.4\% of) local police agencies between 2008 and 2013 (US Department of Justice, 2011, 2015). The number of sheriff's offices decreased at similar rates.

${ }^{2}$ Alternatives to organizational restructuring are changes in police force tactics. Prior contributions primarily address the effectiveness of alternative concepts such as hot-spot policing (Braga et al., 2014; Blattman, Green, Ortega and Tobón, 2017), problem-oriented targeting (Kennedy et al., 2001) or proactive and disorder policing (Kubrin et al. 2010) with respect to preventing criminal behavior.

${ }^{3}$ Police stations are local law enforcement agencies that clear crime at the municipal or county level, and employ the majority of police staff in most countries (e.g. 58\% of full-time employees in the US, see US Department of Justice (2015)). Individual units, however, are often small and employ only little staff.
} 
the municipal-year level. The merger reform took place in the German state of BadenWuerttemberg. Prior to the reform, the state had a very decentralized system of law enforcement with 574 local police stations (Polizeiposten) 4 In 2004, however, the state government decided to close more than 200 police stations for efficiency reasons while retaining the involved staff of local police forces. Police stations were closed in a piecemeal fashion but affected rather small stations which were integrated into larger units. The merger policy led to a large reduction of police stations from 574 down to 367 .

Causal inference of police station closures regarding crime outcomes is, of course, challenging since it is unlikely that these closures are implemented at random by the state government. Instead, policy makers may attempt to close stations in low crime areas and target efforts at crime hotspots (Braga et al., 2014) or shut-down policing in less problematic areas.5 Selection would, in turn, then bias our estimates on crime effects of police station closures in a simple before-after comparison. 6

In order to estimate causal effects of station closures on crime, we use a combined approach of matching as well as event-study methods to account for aforementioned endogeneity concerns. First, matching allows us to retrieve similar counterfactuals for municipalities that undergo station closures using various municipal level characteristics on demographics, local labor markets as well as local government accounts. Second, we estimate crime effects of station closures using event-study methods on a matched sample of closure and non-closure municipalities. Event-studies also allow us to trace treatment effect dynamics after closure events, and importantly, let us to falsify the identifying assumption of common trends of criminal activity in municipalities before closure events. Moreover, we thoroughly test mechanisms. Importantly, we estimate effects on crime detection rates due to closures which helps to rule out incapacitation of police forces and disentangle deterrence effects from incapacitation as the main explanation of our findings.

Our results suggest that police station closures do not affect crime per se including broader crime categories such as crime against life, sex crime and robbery. This may come as a surprise given the substantial number of police station closures and the large salience of the respective closures. However, several factors may explain the lack of effects at aggregate levels. For instance, police officers of closed stations were still re-

\footnotetext{
${ }^{4}$ This amounts to 5,4 stations per 100,000 residents for a population of 10,6 million (similar to state Ohio in the US for example).

${ }^{5}$ For instance, existing evidence indicates that crime is less likely in areas with more favorable demographics or labor market characteristics, e.g. comparably low unemployment (Entorf and Spengler, 2000), wages (Machin and Meghir, 2004) or shares of foreigners (Bell et al., 2013).

${ }^{6}$ Moreover, disentangling deterrence and incapacitation as potential mechanisms of policy changes in policing is empirically challenging (Chalfin and McCrary, 2017b). This is relevant here since police station closures could both change the perceived cost of conducting crimes for potential offenders as compared to the returns from crime through the deterrence channel but could also change the probability of being captured by supposedly more professional police men after police mergers (incapacitation).
} 
sponsible for their old municipality at their new place of assignment. Second, the average additional distance police forces were relocated from a closed station was only $6 \mathrm{~km}$ and even after completion of the merger wave almost every third municipality of the state still possessed a local police station. Also the total number of reported theft cases is left unaffected. However, we find substantial changes in the way local criminals conduct theft crimes in response to police station closures using data on detailed theft crime categories. First, we observe significant and large increases in the number of reported crimes for various theft crimes, including car theft, moped and motorcycle theft as well as apartment and basement burglary. These are goods with typically high monetary value. Second and more surprisingly, we see a robust and steep decline in bicycle theft cases as a typically low valued good type. Given that the overall number of theft cases is unchanged, our findings imply some substitution of low value theft crime towards theft crimes of various more high-end goods in response to station closures. For instance, car theft and apartment burglary have a 19 or 6 times higher average value per case than bicycle thefts, respectively.

The results indicate that these effects are due to behavioral reactions of criminals to station closures, i.e. criminals experience less deterrence due to salient changes in police deployment. We do not find significant effects on detection rates across crime categories, indicating that closures do not impact the efficiency of police forces in detecting relevant suspects for reported crime cases. These findings provide evidence that our results cannot be explained by incapacitation of local police forces (Chalfin and McCrary, 2017b) but rather work through less deterrence from shutting down salient stations. Criminals, in turn, expect less monitoring and lower odds of punishment. In our data, theft crimes of low-value goods also have virtually zero risk of being detected. This suggests that our effects are driven by criminals who feel less deterred but do step up their game.

Our findings are robust to several robustness checks. Importantly, the event-studys indicate that effects are not driven by pre-existing trends that differ across groups. Results are also robust to different specification tests and a placebo test using a fictitious year of closure in the pre-treatment period. Moreover, we do not find that confounding labor market conditions significantly deteriorate after station closures. Finally, our results can also not be explained by a reporting bias for bicycle theft.

The main mechanism for our results is that police station closures increase distances to nearby police stations and local policing becomes less visible. We also rule out other alternative explanations for our findings. First, we do not find that our effects are due to crime displacement as reported theft cases do not change for municipalities that host stations which received additional manpower from closure municipalities. Second, it also appears that station closures do not encourage more people to become criminal but show 
instead that the number of suspects per theft type changes. We find that already active criminals shift their focus from cheaper goods, like bicycles, to more valuable goods.

This paper provides novel causal evidence on the crime effects of an understudied phenomenon of police reorganization, i.e. the shut-down of local police stations. Doing this, we add in at least three ways to the existing literature.

First, we evaluate the crime effects of a substantial contraction in access and increased distances to local law enforcement while most existing studies rely on policies that increase access to policing. To the best of our knowledge, only Shi (2009) and Poutvaara and Priks (2009) studied negative shocks to police deployment when estimating related effects on crime and found that violent crimes increased sharply afterwards.

Second, we study purely administrative changes of local police organization, i.e. police station closures, which lead in turn to a reallocation of local police forces at constant resource levels..$^{7}$ This, is, however, different from prior contributions which repeatedly used exogenous variation in police force allocation from large scale terror threats (Klick and Tabarrok, 2005; Draca et al., 2011; Di Tella and Schargrodsky, 2004). We add to this small but influential literature using natural experiments of redeployments of police forces to study crime deterrence. These papers typically find strong positive responses of street crime to an increase in policing $\bigsqcup^{8}$ We also find stark positive responses in reported cases for various theft categories after a negative shock to local policing, including car theft and burglary. Effects, however, are somewhat lower than in previous studies. Note that large deterrence effects from terror alerts were recently also questioned by Blanes $\mathrm{i}$ Vidal and Mastrobuoni (2017). According to their study, increasing patrolling intensity in normal times does not curb crime. Weisburd (2016) also finds only modest effects. 9 This is well in line with the observed lack of effects on overall crime in our study.

Third, we provide first causal evidence on police (re)organization and the efficiency of law enforcement, measured by detection rates. Reallocating police forces through police station closures does not decrease crime detection rates. Increased distance to crime scenes, however, was previously found to substantially deteriorate detection rates (Blanes i Vidal and Kirchmaier, 2015). Only very few papers study the efficient allo-

\footnotetext{
${ }^{7}$ Thus, we can rule out that crime effects of station closures are due to lower level of police forces. The effect of police manpower on crime levels is highlighted in a vast amount of studies. Although there is a consensus that more police is better for crime outcomes, the magnitudes of the related effects are highly debated (Chalfin and McCrary, 2017b). These studies tackle problems of measurement in crime statistics and simultaneity issues in crime and policing (Levitt, 1997; Evans and Owens, 2007, Lin, 2009, Chalfin and McCrary, 2017b). Recently, Chalfin and McCrary (2017a) show that prior estimates were underestimated by a factor of 4 to 5 and accordingly, US cities are likely underpoliced to fight violent crimes.

${ }_{8}^{8}$ Poutvaara and Priks (2009) find that the reallocation of police forces out of football stadiums in Sweden after terror attacks in the US led to a stark increase of hooligan violence.

9 Heaton et al. (2016) as well as MacDonald et al. (2016) use variation in patrolling intensity of private police around university campuses in Chicago and Pennsylvania, respectively, to study deterrence.
} 
cation of police forces. For instance, $\mathrm{Fu}$ and Wolpin (forthcoming) study the optimal police resource allocation across US metropolitan areas using simulations and find that decentralized decisions on resource allocation are more efficient than centralized actions. In this vein, reducing the number of police stations via closures and mergers into larger stations should decrease efficiency. However, we do not find better detection rates in our sample municipalities.

The paper proceeds as follows. Section 2 describes the institutional background and develops empirical hypotheses. Section 3 outlines our data and provides summary statistics. We highlight our identification strategy in Section 4. Sections 5 and 6 show our empirical results and discuss underlying mechanisms, respectively. Section 7 concludes.

\section{Institutional background and hypotheses}

\subsection{Organizational structure of local law enforcement}

With the exception of some federal police duties, such as border control, asylum legislation or aviation security, law enforcement in Germany is predominantly managed at the state-level. However, there are large disparities across federal states regarding the effectiveness and organization of local law enforcement. Baden-Wuerttemberg has the lowest number of crime cases per capita among the German states (Bundesministerium des Inneren, 2017) and the most decentralized and fragmented system of local law enforcement (Landtag Baden-Wuerttemberg, 2004). According to Figure A.1, state policing covers both law enforcement and other areas, such as state criminal police. Criminal police, however, addresses criminal cases with special demands for crime clearance, such as murder, sexual assault and organized crime. The present study focusses on organizational changes in local law enforcement. State-wide law enforcement is organized by the Ministry of Interior (MI) in four sublayers. First, four state police departments (Landespolizeidirektionen) control and organize police laws and guidelines for their respective jurisdictions 10 These units function as an intermediate layer and were integrated into administrative areas (Regierungsbezirke) in 2005. Second, each of the state police departments are divided into local police departments or presidiums which usually comprise a county or a county free city. Altogether, there were 38 presidiums in our sample period. Third, police departments or presidiums comprise several precincts that deal with local, citizen-oriented and in time criminal cases. In our sample period there are more than 170 precincts. This study, however, focuses on the fourth layer, the so called police stations (Polizeistationen). They are the primary means of contact for residents with police forces,

\footnotetext{
${ }^{10}$ Including the Landespolizeidirektion Stuttgart II which was renamed as presidium Stuttgart in 2005, but which, unlike other presidiums, is a direct subordinate to the MI of Baden-Wuerttemberg.
} 
and are thus both a preventive and corrective arm of the executive branch. From police stations (and precincts in extension) officers go on patrols, offer consultation and act as a point of crime notification for residents. There were more than 570 local police stations in Baden-Wuerttemberg in 2003, which, on average, translates to around one station for every second municipality in the state. The police merger reform of 2004 reduced the number of police stations by large to about 370 stations. ${ }^{11}$

\subsection{Background of the $\mathbf{2 0 0 4}$ police station reform}

Inspired by a recommendation of the state audit court of Baden-Wuerttemberg to optimize local law enforcement through the closure of police stations in the presidium of Mannheim, the state government decided to reform the highly decentralized and fragmented police organization throughout the state. On October 21, 2003, the state government of Baden-Wuerttemberg announced to optimize police structures as part of a larger structural reform of the public sector (Innenministerium Baden-Wuerttemberg, 2012b). Hence the MI instructed the presidiums and departments in 2003 to review their respective police stations in order to improve local law enforcement efficiency by considering the following criteria: $(i)$ Police stations should not have less than 4 employees to provide reliable and professional local enforcement. Thus, the focus was on 302 stations with less than 4 officers. Other criteria were to (ii) increase widely low workloads of police forces, (iii) maintain small distances to the nearest police station, (iv) avoid increases in the number of residents per police officer and to $(v)$ improve policing for local crime hot spots.

Based on these criteria, on January 15, 2004, the presidiums and departments submitted their propositions for local law enforcement reorganizations, including the respective candidates for station closures and the receiving stations to which the affected officers should be reallocated (Landtag Baden-Wuerttemberg, 2004). Initially, the MI only intended to cut 100 police stations. However, after the review of local police stations and recommendations made by the presidiums, it announced in March 2004 to close around 220 of its 570 stations and that these closures should not have any significant consequences for public safety (Schwäbische Zeitung, 2004). According to contemporary witnesses, the stark increase in the number of closures came as a surprise. The presidiums were obliged to make their decisions transparent to the local population and local policy makers but did, however, not require their approval (Gäubote, 2003). Since police station closures and reorganization of police staff was not a political issue but merely a bureaucratic one, no approval from the state parliament was needed (Landtag BadenWuerttemberg, 2004).

\footnotetext{
${ }^{11}$ Police departments and presidiums are responsible for the closure or reallocation of police stations.
} 
Police station closures were implemented in a piece-meal fashion since ongoing rental contracts had to be considered and new real estate for enlarged police stations had to be found (Landtag Baden-Wuerttemberg, 2004) 12 Hence, police stations closed from 2004 onwards although at a decreasing rate (see Figure A.2). Most closure events occurred in the years of 2004 and 2005, with 77 and 67 police closures respectively ${ }^{13}$ Altogether, the number of police stations dropped from 574 in 2003 to 367 in 2011. Figure A.3 illustrates the spatial allocation of local police stations before and after the reform.

The average number of police officers per station increased from about 4 to roughly 6. In line with the priority of closing police stations with less than 4 police officers, the reform substantially decreased these smaller stations. After the reform, however, there were still 67 stations with less than 4 assigned officers. These stations were kept intact due to special local circumstances, distance to the other police stations or differences in local crime levels (Steinmauern Gemeindeanzeiger, 2012). ${ }^{14}$ According to the head of the police labor union of the state, Rüdiger Seidenspinner, police closures made it increasingly harder to be in line with prescribed intervention times of 15 minutes after notification by residents (Stuttgarter Nachrichten, 2009). This is particularly true for rural areas.

The reorganization of local law enforcement was motivated by efficiency arguments, i.e. the reduction of operating costs in the long run, as well as with improved usage of equipment, infrastructure and personnel to cope with increased use of technology (Landtag Baden-Wuerttemberg, 2003). For instance, the Minister of Interior affairs, Heribert Rech, expected annual savings of about 1.5 Million Euros. It was also argued that fewer but larger stations should increase flexibility of police forces (e.g. with longer opening hours of prevailing stations), increased presence at locations with higher crime incidence, and improved professionalism. Police station closures, however, did not decrease the number of police staff but were a mere reallocation of local police forces from municipalities with closing stations to remaining stations. Moreover, police staff from closed stations were still - by large, given the needs of everyday operations - responsible for their old jurisdiction, even though they were transferred to a nearby police station as their new place of work (Landtag Baden-Wuerttemberg, 2005, Amtsblatt Eichstetten - Eichstetter Nachrichten, 2004). Hence, these officers still patrolled their previous pre-closure

\footnotetext{
${ }^{12}$ For example, it was decided that the station Ulm-Jungingen was closed and its officers were to be allocated to Dornstadt station but the actual closure had to wait until new real estate facilities opened up in 2006 to accommodate the new police officers (Schwäbische Zeitung, 2006).

${ }^{13}$ Earlier closures from 1990 to 2003 were more scarce and not due to state-wide reform. For instance, 5 smaller stations in Mannheim just closed before the reform (Audit Court Baden-Wuerttemberg, 2002).

${ }^{14}$ Note that we evaluate crime effects of station closures using a matching procedure of affected and nonaffected units and importantly, rely on similar trends in criminal activity between our groups of comparison in our event-study approach (see Section 4). We believe to capture any potential selection issues of police station closures with respect to criminal activity and police performance with our identification strategy.
} 
town but had to travel farther from their new assigned workplace to their old jurisdiction after the reform 15 These transferred officers often also offered consultation hours in their old jurisdiction, but, had to travel farther in case of notification regarding a criminal case by the local population.

The reform was accompanied by some other changes to the police organization (see Innenministerium Baden-Wuerttemberg, 2012b) ${ }^{16}$ Importantly, these accompanying changes are similar for municipalities with or without police closures and should thus not bias our empirical results on crime effects from police closures on the municipal level.

\subsection{Theoretical considerations on police closures and crime}

In order to path the way of our empirical analysis of the effect of local police station closures on crime, we first discuss which criminal activities are likely to be affected by station closures. Then, we develop theoretical predictions regarding related crime effects.

What type of criminal activities could be affected from station closures? To answer this question it is important to understand the incentive effects of local station closures in regard to criminal activity. Incentive effects differ across crime type. For example, in the field of violent crime incentive effects are found to be relatively weak (Freeman, 1999, Machin and Meghir, 2004). In this crime category contextual and environmental factors are important. For instance, forms of stress such as helplessness and mental overload may inspire violence (Kaiser, 1996) and assault towards family members (Card and Dahl, 2011). The selection of individuals into specific situations or environments, such as crowded places, increases the likelihood of becoming either a criminal or a victim. Accordingly, substantial self-selection of individuals with initial criminal potential into specific situations often lead to violent crime (Walter, 2008). On psychological grounds, violent crime at the individual level may increase after individual failure and may become an instrument for compensation (Boatca, 2004). Regarding violence and body-related criminal activity, the literature has shown the importance of noncognitive skills and preferences such as patience and identity. Blattman, Jamison and Sheridan (2017) and Heller et al. (2017) report that cognitive behavioral therapy can reduce violent crime in particular.

Violent crime, therefore, may be considered as outside of the rational crime paradigm where it is also difficult to derive a proxy for expected returns (Draca et al., forthcoming).

\footnotetext{
${ }^{15}$ Note that keeping the same officers responsible for their old jurisdiction preserved valuable local knowledge about criminal suspects, residents and the place (Landtag Baden-Wuerttemberg, 2005).

${ }^{16}$ First, all four state police departments but one were integrated into the administrative districts. State police department Stuttgart II became subordinate to the MI. Second, special police forces such as the highway and water police departments were integrated into police presidiums and local departments. Third, the economic control service (Wirtschaftskontrolldienst), responsible for food control, was transferred from police duty to the county level. Lastly, police working hours were prolonged to 41 hours.
} 
The visibility, or actual presence, of police officers and local police stations due to the reform may not, or is unlikely to be, in the decision space of violent criminals. Therefore, the reform is unlikely to affect crime such as homicide and sexual assault.

Local police station closures represent a policy change that might alter the cost-benefit relationship from participating in criminal activities in other categories such as street and property crimes. Street crimes, and particularly theft cases, are susceptible to deterrence through police presence (Draca et al., 2011). In general, deterrence relates to certainty, severity, and celerity of punishment. Police station closures may be seen as a change in the threat of punishment (Chalfin and McCrary, 2017b). Closures of local police stations were widely communicated in local newspapers before and at the time of closure within and across municipalities ${ }^{17}$ The closure of police buildings and the reallocation of police forces to other surrounding stations affects the physical visibility of the police in a given municipality and lowers the time spend in that municipality at least due to an increase in driving distance. This suggests that potential offenders are aware of policy changes (Apel, 2013).

The workhorse model of crime in the economics literature to explain criminal participation dates back to Becker (1968) and Ehrlich (1974). The partial model relates expected labor markets earnings and earnings from criminal activity to the crime rate. It can explain why we observe crime in societies and what happens to criminal behavior if policy variables (e.g. the severity of criminal sanctions or the probability of punishment) change. Within this model, the probability of punishment might be a function of police visibility. Accordingly, the reallocation of police forces from locality A to locality B might reduce the probability of punishment in A and vice versa for B. The result would be an increase (reduction) in the level of crime in place A (B).

Whether such a change refers to deterrence or incapacitation is generally hard to determine. We can speak of policy deterring crime if a policy change induces individuals to elect not to engage in crime. A policy change, however, might take offenders out of circulation and thus prevent crime by incapacitating criminals (Chalfin and McCrary, 2017b). In order to identify an incapacitation effect, we need to observe a change in the probability of capture, whereas deterrence can be present in response to any policy that changes the cost-benefit relationship. In the empirical application, we will proxy the probability to capture using detection rates. 18

Besides the empirical analysis of reported crime cases and the relation to deterrence and incapacitation, we can further test whether the policy change induces non-criminals

\footnotetext{
${ }^{17}$ See for example https://www .schwaebische.de/home_artikel, -_arid, 1042848.html

${ }^{18}$ However, a clear distinction between deterrence and incapacitation in empirical application is challenging and the two mechanisms through which the criminal-justice policy change crime are often simultaneously in place.
} 
to become criminal or whether the observed effects are driven by already active criminals using data on suspects. Interpreting crime as an occupational choice, this relates to the discussion of costs of occupational mobility (Cortes and Gallipoli, 2018). If the policy change induces new criminals, this could be interpreted as lower levels of deterrence and that returns to crime are higher than labor market returns minus occupational mobility costs. Deterrence, however, may also be in place among active criminals if e.g. already active criminals change behavior by increasing their activity. Increasing initial criminal behavior depends on time allocation (Lemieux et al., 1994, Lee and McCrary, 2017). Adjustments are, for example, less time for leisure or legal market activity. It is, however, also possible to move to goods with higher values and leave aside goods with low values. In the first situation, we would observe an increase in reported crime for at least some goods. The latter situation allows for a reduction in some crime categories with low market values and a simultaneous increase in other crime categories in response of station closures.

Our empirical analysis also relates to the literature on actual and perceived risk of crime. Recent studies find strong evidence for a low correlation between actual and perceived risk (Kleck et al., 2005, Kleck and Barnes, 2014). Forming expectations about risk comes, therefore, with large errors. In particular, individuals who commit crime and avoid being arrested systematically underestimate their subjective probability of apprehension (Apel, 2013). The next section shows that the probability of being detected as a criminal varies substantially among crime categories. This is true in particular for theft with detection rates among e.g. bicycle theft of close to zero. Detection rates of virtually zero also mean that an additional push factor due to a police station closure is likely to be absent. Criminals within categories of low risk of capture may still react to station closures by shifting resources towards other goods. Depending on the degree of activity in low risk crime categories in correspondence with leisure and legal market activity decisions, these criminals might be most likely to increase activity among other goods. This would result in an increase in crime cases among other goods and either (1) no change of crime cases within the low-risk goods or (2) a reduction of crime cases within the low-risk good.

\section{Data and descriptive statistics}

Data We draw detailed municipal level data from various sources. First, we gathered data on police station locations in Baden-Wuerttemberg for the period 1990-2011. A list of all police stations (including their respective staff size) as well as suspected targets of police station closure is available for the advent of the reorganization law (Landtag BadenWuerttemberg, 2004). We hand-collected other information, such as date of closure as 
well as type of reorganization, i.e. which stations were integrated into which prevailing stations. We exploited various web-based sources of local newspapers or called local experts, i.e. town halls and current police stations in cases if no central database on local policing was available. After all, we use a sample period 1996 to 2011 for empirical analysis both to gain a sufficient number of years before the majority of closures starts in 2004 and to avoid including a confounding reorganization policy of upper tier police forces in 2012 19

Regarding municipal crime data, we rely on rich information from the State Criminal Office (Landeskriminalamt) in Baden-Wuerttemberg from 1996-2011. Our crime data covers detailed information at the municipal-year level with respect to reported crime cases and detection rates, as well as monetary damage incurred for a large amount of crime categories. Table A.1 provides an overview of the available information and the respective summary statistics for all municipalities in the overall sample. As argued in Section 2.3. we focus on the effects on detailed categories of theft activities (such as car, moped including motorcycle and bicycle theft or apartment and basement burglary), but also report effects on total crime, crime against life, sex crimes and robbery. Moreover, we use crime against public order as a proxy for physical presence of local police forces.

In addition to information on station closures and criminal activities, we exploit municipallevel variation in various socio-demographic characteristics on the municipal level, as well as labor market information (see Table B.1 for an overview). In our empirical analysis we use these variables to match municipalities that experienced closures with non-affected but comparable municipalities, based on the distribution of their pre-reform characteristics across these variables. We gathered data on the demographic structure of the municipalities, such as age, skill level, female population share, share of foreigners in the population as well as municipal revenues and expenditure (income and commercial revenue, public safety and law and order expenditures and the public deficit) from the statistical office of Baden-Wuerttemberg. Moreover, we draw administrative information of local labor market indicators from the Institute of Employment Research (IAB), including average real daily wage, the unemployment rate and the share of individuals in active labor market programs. ${ }^{20}$ The IAB also provides the local occupational structure for 6 broad occupations at the municipal level. Both labor market conditions of the local population, as

\footnotetext{
${ }^{19}$ The reform left the number of precincts and local police stations untouched but reduced the number of state police departments and presidiums from 4 and 37 down to 12 large units in 2014. This policy -just like the local station reorganization- aimed at long term savings in infrastructure, personnel and equipment (Innenministerium Baden-Wuerttemberg, 2012a).

${ }^{20}$ This administrative data set covers a $2 \%$ random draw of the universe of all individuals who have at least one entry in their social security records since 1975 in West Germany and starting from 1992 in East Germany. The data covers approximately $80 \%$ of the German workforce and provides panel information on individual employment biographies. Self-employed workers, civil servants, and individuals doing their military service are not included. For detailed information see for e.g. Oberschachtsiek et al. (2008).
} 
well as the economic structure, are important confounders to the effects of police station closures on local criminal activity which is the focus of our analysis.

Descriptive statistics Table A.1 provides descriptive statistics on reported crime cases, detection rates, and damage incurred for several crime categories in all municipalities for 1996-2011. There is substantial variation across all of these dimensions of criminal activity. For instance, there are, on average, about 530 crime cases per municipality and year in total. That makes Baden-Wuerttemberg the state with the lowest crime incidence rate in Germany (Bundesministerium des Inneren, 2017) with only 5,599 reported cases per 100,000 residents in 2016. Most crime categories, such as crime against life (for example homicide) or sexual assault, are relatively rare, whereas theft makes up about $41 \%$ of all reported crime cases. However, relative to other European countries, theft rates in municipalities used in this study are relatively low with around 1,191 reported cases per 100,000 residents (as compared to the EU average of 1,603 cases, see Eurostat (2018)).

Moreover, detection rates for theft are well below average detection rates in BadenWuerttemberg with $28 \%$ versus $58 \%$, respectively. ${ }^{21}$ Within the broader theft category, smaller scale activities in particular, such as bicycle theft have a clearance rate below $10 \%$, whereas car theft performs better, though still below average, with about 4 in 10 cases cleared. Also moped theft and burglary from apartments and basements, for example, have higher detection rates than bicycle theft. Other crime categories such as sexual assault, violent crime, or crime against life, however, have relatively high detection rates at $81 \%, 92 \%$ and $96 \%$, respectively. Theft also causes about $25 \%$ of monetary damages incurred by all crimes reported in the sample period comprises partially small average monetary damage per case as compared to all crimes committed, e.g. bicycle theft. However, other types of theft have higher monetary damages per case including basement burglary and moped theft. Note that especially apartment burglary and car theft have high monetary values with on average about 6 or 19 times the monetary value of bicycle theft cases.

\section{Empirical strategy}

In our empirical strategy, we combine matching with an event study approach, allowing for flexibly tracing criminal activity in municipalities after a police station closure compared to matched control localities. We first present the matching approach and then show

\footnotetext{
${ }^{21}$ Some values of detection rates (see maximum values in Table A.1 exceed values of $100 \%$ which might come from the fact that police officers clear more cases than being reported in a given year. This may arise, for example, if crimes cases conducted in December are solved in January of next year.
} 
the identification strategy for our generalized difference-in-differences and event-study design.

\subsection{Matching treatment and control regions}

The main econometric challenge we face with our control group approach is that treated and control units might differ systematically. Table B.1 shows simple difference of means tests for municipalities with a police station closure between 2004 and 2008, and all other municipalities measured before the treatment event. For instance, municipalities experiencing police closures have on average less unskilled residents but comparably more foreigners. Also unemployment rates are systematically higher in treated localities. Closure municipalities also have larger public deficits. Hence, a treated municipality might be on a different crime trajectory not only because of the police station closure but also due to confounded factors at the municipal level. Indeed, municipalities experiencing police closures are quite different from those not experiencing such events before the reform.

Hence, we construct counterfactuals by matching a similar control municipality to each treated municipality affected by the police reform starting in 2004. Our matching variables cover the demographic structure of the region (age, skill level, female share and share of foreigner), local labor market indicators (average real daily wage, unemployment rate, share of individuals in active labor market programs, the occupational structure using 6 broad occupations) and revenues and expenditure at the municipal level (income and commercial revenue, public safety and law and order expenditures as well as the public deficit). For the chosen variables matching is done based on the figures reported for one year prior to the policing reforms, and four years prior to the policing reforms, in order to capture differences in levels as well as potential pre-trends of the selected confounding variables. Importantly, we do not match on outcome variables in order to evaluate common pre-trends in criminal activity with our event-study approach (see Section 4.2).

We use a Mahalanobis matching procedure to find suitable control municipalities. This algorithm minimizes the standard Euclidean distance of all matching variables. In particular, this algorithm uses municipalities as controls which show the smallest sum of normalized squared differences. Following Stuart and Rubin (2008) Mahalanobis matching should not employ too many matching variables such as 3-digit occupational codes.

In order to find suitable control units, we impose a couple of restrictions. In total, we observe 235 police station closures between 1996 and 2011. We restrict the control units to not be a direct neighbor of the treated municipality to exclude that spatial spillovers drive our results. We further apply four other restrictions. First, we exclude 22 municipalities that have experienced a station closures since 1996 to exclude that the results may be driven by long-term effects of events prior to the reform. Overall, this restriction leads 
to the exclusion of 36 treatment events due to multiply treatments over time. Second, we exclude 128 municipalities that received police officers from the closing stations, to ensure that we measure the effect of the genuine closures and do not simply compare treated towns with those who have increased staffing levels ${ }^{22}$ We analyze the crime effects for municipalities which received additional officers in existing police stations separately in Section 6.5. Third, we drop 5 municipalities with changes on the precinct-level. Fourth and last, we drop treated localities which still possess a police station after a closure event. That is, we focus only on closure municipalities that have no police station after the closure event and where distance to the next nearby police station thus increases after the station closure. This allows us to identify the effect of having a police station on criminal activity at the town level and avoid confounding effects from other remaining stations.

Altogether, this leaves us with 175 municipalities affected by reforms in 2004 or thereafter, and 757 potential control localities. In our empirics we ultimately only analyze 167 closure events until 2008 in order to have a sufficient number of post-treatment observations. Table B.1 shows the results of the difference in means test for our 167 treated and 167 matched control municipalities. Importantly, the matching approach works very well in terms of matched control variables. None of the variables measured in the year prior to the reform as well as four years before the reform differ statistically between treated and control units. Figure B.1 shows the spatial allocation of treated and control units across the state. The map indicates that the municipalities are not clustered in certain regions.

\subsection{Identification and estimation procedure}

Difference-in-differences. Using our matched treated and control municipalities, we compare levels of crime outcomes in municipalities with police closures with outcomes in control municipalities without closures before and after the closure events. We first estimate a simple generalized difference-in-difference model of the following form:

$$
\log \left(\text { crime }_{i \tau t}\right)=\beta_{1} \text { closure }_{i t}^{\tau}+\mu_{i}+\lambda_{t}+\theta_{\tau}+\varepsilon_{i t}
$$

where $\tau$ denotes relative year and $t$ actual calender year. crime $i \tau t$ refers to the number of reported crime cases for several crime categories in municipality $i$ and year $t$. The crime categories we use range from total number of all crimes and broad crime categories such as crime against life, sexual assault, robbery as well as theft to more detailed crime categories. We focus on detailed reports of theft incidences such as car, moped and bicycle as well as apartment and basement burglary. We also use detection rates and monetary

\footnotetext{
${ }^{22}$ This restriction also excludes five treated municipalities with an increase in police officers before 2004.
} 
damages in Section 6 to shed more light on the mechanisms of our baseline results 23 Since we log-linearize crime outcomes to ease interpretation and some types of crime were not committed in all municipality-year pairs, we add values of one to counter zero values. In the main analysis, we choose 5 years before the treatment and 5 years after the treatment, thus, $\tau$ takes values between -5 and 5. The main variable of interest, closure ${ }_{i t}^{\tau}$, is an indicator equal to 1 for municipalities with a police station closure following the years after the reform, $\tau \geq 1$ and zero otherwise.

We introduce relative year $\left(\theta_{\tau}\right)$ and calender effects $\left(\lambda_{t}\right)$ to ensure that we compare treated and control regions in the same calender year and relative before and after the treatment. Note that $\lambda_{t}$ and $\theta_{\tau}$ can differ because closure events do not occur in the same year but different actual events vary across calender years. $\mu_{i}$ represents municipalityfixed effects. Given that the variation comes from the municipality level, we cluster standard errors at the level of the municipality (Bertrand et al., 2004). The main coefficient of interest $\beta_{1}$ measures the average treatment effect of police closures on our crime variables.

Event-study design. We extent the previous model by estimating treatment effects for every year before and after police closures. We estimate the following event-study model:

$$
\log \left(\text { crime }_{i \tau t}\right)=\sum_{\tau=-5}^{-2} \beta_{\tau} \text { closure }_{i t}^{\tau}+\sum_{\tau=0}^{5} \gamma_{\tau} \text { closure }_{i t}^{\tau}+\mu_{i}+\lambda_{t}+\theta_{\tau}+\varepsilon_{i t}
$$

This model allows us to assess whether the effect of the reform varies over time. As with the generalized difference-in-difference approach, the main identifying assumption of the event-study regressions is that municipalities with and without police closures follow similar trends in criminal activity before the closure. Since we do not match on outcome variables we can assess the plausibility of this notion by comparing pre-treatment trends in outcomes between treated and untreated municipalities. Specifically, we test whether $\beta_{\tau}$ differs from zero. We show in Section 5 that the $\beta_{\tau}$ coefficients are indeed close to zero and statistically insignificant. Hence, the underlying common trend assumption for the difference-in-difference and event-study design appears to be valid. Moreover, estimating year-specific treatment effects of police closures in equation (2) by means of $\gamma_{\tau}$ allows us to measure short and medium-run effects after police station closures. Note that all treatment effects of police station closures on our outcome variables are evaluated relative to the pre-reform year $\tau=-1$. Again, we use logarithmic figures of our dependent variables and account for zero values by adding values of one as is standard practice. Given that we run our event-study estimations on a well matched sample of treated and control municipalities, we identify the causal effect of police station closures on crime under very weak

\footnotetext{
${ }^{23} \mathrm{We}$ also check crime rates per 1,000 inhabitants as alternative outcomes. Results remain unaltered.
} 
assumptions, namely as long as the unobserved selection bias (beyond our matching variables) is changing over time. However, evidence of similar pre-trends between municipalities with and without police station closures across different crime categories provides suggestive evidence for the plausibility of the common trends assumption. We also provide different robustness tests to support this notion, including placebo tests and checks on whether our matching variables develop differently after station closures between our comparison groups. This further easens worries on time-varying selection issues.

\section{Empirical results}

\subsection{Baseline results}

We start by presenting our results of police station closures for broad crime categories and then focus on specific sub-categories. That is, we organize the presentation of the baseline results first for broad crime categories (all crimes, homicide, sex crime, robbery, theft) and then provide estimates for detailed theft categories 24 We first present average treatment effects of police closures using generalized difference-in-differences and proceed with illustrating effect dynamics and similar pre-trends with the event-study design.

Difference-in-Differences. Table C.1 shows that, we do not find any effect of the police station closures at the municipal level for crime in total as well as for most broad crime categories. The lack of effects of police force reallocation, here studied through police station closures, on overall crime and violent crimes as well as theft is in contrast with previous findings (Klick and Tabarrok, 2005; Draca et al., 2011). This may come as a surprise given the substantial number of police station closures and the large salience of the respective closures. However, several factors may explain the lack of effects at aggregate levels. First, police officers of closed stations were still responsible for their old municipality at their new place of assignment. Second, the average additional distance police forces were relocated from a closed station was $6 \mathrm{~km}$. Third, violent crimes such as homicide and sex crime are not the primary responsibility of local police forces but of state-level criminal police. Moreover, we would not expect significant effects on criminal behavior in neither total crime nor violent crime since the pure presence or visibility of police officers is unlikely to affect these crime categories as argued in Section 2.3. Closing a police station nevertheless increases reported cases of robbery by $8.5 \%$ on average after the reform. Results are significant at the $5 \%$ level. While robbery represents a special case of theft with interpersonal contact, we do not find an effect of police station closures

\footnotetext{
${ }^{24} \mathrm{We}$ also show results for the subcategories of homicide, sex crime and robbery in Online Appendix A.
} 
on total theft. However, albeit the lack of aggregate effects for theft we can show that there are changes in the nature of how theft crimes are committed in response to local police station closures using detailed data on various types of theft crime.25

Table C.2 shows the results for several theft categories. We focus here on the categories of car, moped and bicycle theft as well as on apartment and basement burglary 26 The results suggest heterogeneous effects across different categories of theft and changes in the way theft crimes are committed. Police station closures lead to significant increases of car theft and burglary in apartments. Both effects are highly significant at the $1 \%$ level and also relatively large with point estimates around 17\%. The response of these susceptible categories (Draca et al., 2011) is in line with existing evidence of police targeting (Di Tella and Schargrodsky, 2004; Klick and Tabarrok, 2005; Draca et al., 2011). Moped theft and burglary in basements also significantly increase in response to station closures but effects are somewhat lower. Interestingly, reported cases for bicycle theft not increase but do, in fact, substantially decrease when experiencing police station closures. The effect for bicycle theft is not only significant at the $1 \%$ level but also economically sizable as they translate to an average decrease of about 3 stolen bicycles when evaluated at the sample mean.

These findings suggests that the nature of theft crimes change in response to police station closures. Several theft categories show positive effects in reported crime at the expense of bicycle theft but without affecting the overall number theft cases. Our results suggest that criminals react to a decline in salience of local policing and larger distances to nearby stations after police station closures, which positively affects the expected return from crime. Thieves in turn also shift their attention away from low-value goods such as bicycles and towards high-value goods. This is especially true for cars and apartment burglary which have a 19 or 6 times higher average value per reported crime case as compared to bicycle theft, respectively (recall Table A.1). This also holds for moped and basement theft although to a lesser extent. We will later see in Section 6 that overall monetary damages for car and apartment burglaries more than double after police closures but that average values of stolen items do not change. Hence, thieves change their focus to more valuable good types but the average values do not increase likewise. Hence, theft increases only in quantity in these more high-end goods. This finding is consistent with

\footnotetext{
${ }^{25} \mathrm{We}$ do not find significant effects for detailed sub-categories of body-related crimes. Online Appendix Table OA-A.1 illustrates the respective results for crime against life, such as homicide, manslaughter and involuntary manslaughter, and sex crime. Sex crime includes violence or dependency, sexual abuse as well as utilization of sexual tastes. All point estimates of police station closures are close to zero and insignificant.

${ }^{26}$ The data set also provides information on gun theft, theft of antiquities and cashless payment methods as well as bank and hotel burglary. However, these categories are not relevant, i.e. are performed on average less than once in all municipality-year pairs. Second, and most important, only sub-categories are shown where we can provide credible effects of station closures, i.e. theft categories without significant pre-trends.
} 
the fact that prices of goods are an important incentive for theft (Draca et al., forthcoming). 27

Event-study design. Thus far, the results represent average effects of the reforms and neglect dynamic treatment effects. We will now turn to the event-study approach from equation (2) to study treatment effect dynamics, and to validate our identifying assumption of common trends of reported crime in closure versus non-closure localities. In what follows, we present relative effects with respect to the pre-reform year, $\tau=-1$. This allows us the assess the model assumption of a common pre-trend directly and test whether the effects differ by post-reform years. We focus first on detailed theft categories.

Figure C.2 shows evidence from event-study estimations which are supportive of the aforementioned substitution of criminal activity within theft, eg. from bicycle theft as a low value product towards more valuable activities such as car theft, moped theft as well as apartment and basement burglary. For instance, car theft rates begin to increase immediately after the closure event and become significant at the $5 \%$ level with estimates of around $15 \%$ one years after the closure event. Moreover, the increase is not only immediate but also permanent as effects level at around $20 \%$ increases and increase somewhat more at $t+5$. Similar observations of immediate and permanent increases for apartment and basement burglary. Moped theft, however, does not respond significantly in the posttreatment years, although one can observe a stark increase of the relevant point estimate one year after the police closure. In line with our difference-in-differences findings, bicycle theft decreases strongly and permanently after the closure event. Effects level at about $-10 \%$ in the aftermath of the station closures. Importantly, all event-study plots show similar crime developments before the closure events in the respective theft category ${ }^{28}$ This gives us confidence that we can provide credible and causal estimates with respect to these theft variables given that the underlying assumption of common trends for our difference-in-difference and event-study approach seems to hold, respectively.

Figure C.1, as well as Online Appendix Figures OA-A.1 and OA-A.2, plot the coefficients along with the $95 \%$ confidence interval for all broad crime categories as well as detailed subcategories within body-related crime. Reassuringly, the common pre-trend assumptions are justified for all of these crime categories. This provides supporting ev-

\footnotetext{
${ }^{27}$ According to Table OA-A.2 in the Online Appendix, we do not find significant effects of police closures on various sub-categories of robbery including robbery of banks/post, patrol stations, drug-related and apartments. Thus, the effect on overall robbery does not seem to be significantly driven by specific sub-categories. Changes in the nature of property crime from police station closures seem not to matter for robbery as they did for theft cases. Unlike robbery, theft does not involve interpersonal contact.

${ }^{28}$ Note that moped theft seems to be significantly lower in the pre-reform year $t-4$. However, we have confidence in our results about this outcome since there are no discernible differences in trends and the immediate years before the closure event are not significantly different for our comparison groups.
} 
idence that prior to the treatment, trends in criminal activity did not differ by treatment status. Overall, estimates of closure effects are all relatively close to zero - including for robbery - which suggests that the police station closure had no effect on these types of crime rates. Hence, the $8.5 \%$ increase in overall robbery from Table C. 1 is not supported in our event-study specification and might be considered spurious.

\subsection{Robustness of results}

This subsection provides evidence on the robustness of our baseline results with respect to various sensitivity checks. First, we use all municipalities as potential control units for our matching procedure and do not exclude directly adjacent neighbors. Second, we use all closure events between 2000 and 2010 and include 22 closure events before 2004 and 8 after after 2008. Third, we use reported crime cases measured in per 1,000 inhabitants instead of log reported crime cases as our outcome of interest. Fourth, we include districtspecific time trends in our regressions in order to increase precision. Fifth, we provide another piece of evidence on the validity of our common trend assumption by employing placebo tests with a fictitious reform event before the actual implementation. We perform these placebo tests using a treatment date of 1999 on a reduced sample of 1996-2003. Doing so, we maintain 5 post-treatment years which do not overlap with the true postreform period. However, this also reduces the pre-reform years down to 3 .

Table D.1illustrates the respective results for these sensitivity checks and our detailed theft categories. The results are highly robust for car and bicycle theft as well as for apartment burglary. However, moped and basement burglary turns are somewhat less robust regarding some specifications. Moped theft turns statistically insignificant when considering matching including all possible neighbors and all events in 2000-2010. However, the point estimates remain similar but significance is lost due to a decrease in precision with standard errors increasing in these specifications. Basement burglary turns, however, insignificant when considering per capita outcomes. Note that both moped theft and basement burglary occurs on average less often than car, bicycle and apartment theft which could explain a lack of precision in these alternative specification and in turn somewhat less robust results. All of the theft categories considered pass the placebo test which further alleviates potential worries about the validity of the common trend assumption underlying difference-in-differences and the event-study. Altogether, our findings suggest again that police station closures lead to significantly more reported car and moped theft as well as burglary in residential property while bicycle theft substantially decreases.

Another threat to our findings are worsening of local labor market conditions after police station closures. If closures lead to lower labor market activity or selective outmigration, these confounding factors may explain our observed crime effects instead of 
police closures. Note that we match on similar labor market conditions prior to treatment, such as real daily wages, number of employees and local tax income for closure and non-closure municipalities. Table B.1 shows balanced pre-treatment values of local labor market conditions between both comparison groups. However, labor market outcomes could worsen from a decline in local amenities (here, local law enforcement quality) due to police station closures. Hence, we provide balancing tests (Pei et al., 2017) by using real daily wages, number of employees, local tax income and number of residents as alternative outcome variables in our event-study. These variables do not move differently for treated and control units (see Online Appendix Figure OA-C.1).

Police station closures might also change reporting behavior of local residents. In other words, can the negative effect for bicycle theft (as opposed to the increase in other theft categories) be explained by a reporting behavior? Higher distance might increase the (time) cost of crime reporting. If this was the case, we would expect that less severe cases were less likely to be reported, which would in turn result in higher monetary damages per reported case. Thus, we estimate whether the average monetary damage per reported case changes as a response to police station closures. If average monetary damage per reported case increased, this would provide suggestive evidence that residents had less incentive to report. However, related difference-in-differences results across theft categories suggest that police station closures do not affect damages per case (see Table D.2). This would be of particular importance for bicycle theft given our estimates of lower reported effects after station closures and the relatively small damages per case for bicycle theft. However, reported damages for bicycles did not increase after police station closures, making a change in reporting behavior among the affected local residents unlikely.

\section{Mechanisms}

\subsection{Analyzing detection rates}

This subsection investigates changes in local law enforcement efficiency as a potential explanation for (widely absent) crime responses to police station closures. To do that, we use changes in detection rates across crime categories in response to police station closure as alternative outcome variables. Detection rates are defined as the number of detected cases per reported crime case. 29 Thus, we provide evidence whether or not our estimated effects on reported crime occur due to incapacitation of local law enforcement rather than via crime deterrence. We also provide novel evidence on whether police station closures as a means of administrative reorganization and police deployment - changed efficiency

\footnotetext{
${ }^{29}$ The police defines a crime to be detected or cleared if one or more suspects to a case are found.
} 
(as measured by detection rates) of local police forces. Note that we do not measure incapacitation as actual incarcerations but as detection of suspects by police forces only. Detecting suspects, however, is a legal perquisite of clearing a crime case and should thus raise the probability of capture and legal punishment substantially. Accordingly, we argue that detection rates indeed represent a valid proxy of local police efficiency.

Our results suggest that detection rates do not significantly respond to station closures at conventional levels. We find null results for theft in total, as well as our main theft categories (see Figure E.1). Importantly, also neither car theft, moped theft, burglary in apartments or basements nor theft in total seem to have significantly different detection rates after police station closures in our sample. This rules out incapacitation as the main channel for increased numbers reported theft in various subcategories but leaves less crime deterrence after closures as the main explanation. However, police work improves somewhat regarding bicycle theft from year three after the closure event onwards. However, given that this effect is not immediate, it is unlikely to explain our observation of an immediate and substantial drop of bicycle theft after station closures. This results might also be a hint that the more able thieves become less active within bicycle theft which in higher detection rates. Again, the event-study plots give support to our identifying assumption of common trends ${ }^{30}$

Missing effects of police closures, and hence, longer driving distances to a nearby police station on detection rates are in line with Bayley (1996), who argued that response time matters only for crime detection in the first minute. However, police notifications of criminal activity are usually too long to make the speed of any police action relevant (Sherman et al., 1997). Hence, most existing studies agree that response time is not related to detection rates given that most notifications are done relatively late (Nagin, 2013). However, Blanes i Vidal and Kirchmaier (2015) contradict these results and find strong effects of response time on detection rates in the Greater Manchester area. We argue that, unlike Blanes i Vidal and Kirchmaier (2015), we do not identify local treatment effects of distance but average effects of police station closures in a sample of relatively rural areas.

Our results on detection rates provide evidence that changes in theft after station closures are not driven by incapacitation but may rather come from lower crime deterrence which is consistent with insights from previous studies related to the reallocation of police forces (e.g. Di Tella and Schargrodsky, 2004). Moreover, our findings suggest that law enforcement efficiency (measured as detection rates) hardly respond to station closures.

\footnotetext{
${ }^{30}$ The event-study plots aggregate pairs of two subsequent years into one observation to gain statistical power since we only observe detection rates if a crime is committed in given year and crime category. Online Appendix Figure OA-B.1 shows also null effects for total crime, crime against life, robbery and sex crimes.
} 


\subsection{Monetary crime damage}

We also study the changes in monetary damages from crimes committed. First, this aspect provides some supporting evidence for our treatment effects on reported crime cases. Second, this allows to analyze whether property crimes are becoming more or less valuable in response to police station closures. Note that our damage data reflects estimates on market values for property crimes ${ }^{31}$ Again, information on monetary damages is available across crime categories on the municipality-year level. Monetary damage data for violent crimes, including our broad crime categories of body-related and sex crimes, does, however, not exist. We rerun our previous models with damage data across crime categories as our outcomes of interest. Monetary damage is measured in real euros based on 2010 prices. Unfortunately, data is only available from 2003 onwards. This reduces the number of pre-reform years available, e.g. for 2004 events we only have one pre-reform year but more for later events of course. Thus, we restrict the analysis to 3 pre-reform years.

A more general observation is that overall monetary damage of all crimes committed, robbery or all theft crimes does not change in response of the reform (unreported). Altogether, damages from property crimes are not becoming larger through police station closures per se. However, there may be different effects across our various theft categories. Figure E.2 now present the respective event study results. Given substantial variation of estimated monetary damage observable for related criminal activities, standard errors as well as confidence intervals increase relative to previous illustrations. We observe positive effects for monetary damage values for car theft one, two and four years after the reform. The point estimates are very large with damage increases of more than $100 \%$ in these post-reform years but they are only significant at the $10 \%$ level given the large standard errors. Also burglary from apartment shows increases in monetary damages at similar magnitudes and is partly significant at the $10 \%$ level. Bicycle and moped theft as well as basement burglary, however, do not experience a change in overall monetary values due to station closures. Furthermore, we find that average damage per reported crime do not change across crime categories in response to the reform, implying that crime effects are driven by changes in the number of crimes rather than changing average monetary values of the respective crime cases. This is true for crime in total, our broad property crime categories as well as our detailed theft categories ${ }^{32}$

\footnotetext{
${ }^{31}$ Please note that these numbers only reflect direct estimates of monetary damages for crimes committed, but do not include other substantial costs of crime such as loss of human capital via incarceration or death, which are estimated to be much higher for violent crimes and particularly for murder (see Chalfin and McCrary, 2017a for a welfare analysis of policing across crime categories).

${ }^{32}$ The respective results are available on request.
} 


\subsection{Reduction in police salience and physical presence}

The salient closures of local police stations may deter fewer potential offenders from committing crimes rather than incapacitating local police forces, which we found to be widely absent in Section 6.1. Given that police officers are still responsible for the municipality where their police station closed down, the closures caused an increase in driving time which is likely to be associated with less time spent in the region (e.g. fewer patrolling hours and/or longer response times). Thus, lower police presence might lead to less crime deterrence. We test this mechanism indirectly by analyzing crime against state/public authority. Lower police presence likely decreases contact of local residents with police forces which would result in fewer reported crime cases against public authorities.

The results in Figure E.3 show that crime against public authorities decreased in the two years after the reform, which would be consistent with the fact that the time police spent in the reform municipality decreased. Effects continue to be negative thereafter but turn insignificant. We interpret the decrease in crimes against public order as indicative for lower physical presence of the police for the respective municipalities. This is, in turn, suggestive for lower levels of crime deterrence and police salience after a station closure. Lower physical presence of police forces then translate into significantly higher rates of theft for cars, mopeds and burglary in apartments and basements.

\subsection{Countervailing policy responses at the local level}

As an extension to our findings, we also check whether possibly confounding policy choices of local governments undergo significant changes due to police station closures. Municipalities might increase their spending on public safety in general (including local police issues, fire fighters, law and order, environmental protection) or law and order in particular as a response to police station closures. Recall that police changes studied in this paper are part of the state police but local governments have some scope to counteract changes made at the state level.

Interestingly, Figure E.4 indicates that neither spending category reacts significantly immediately after the closure events. Moreover, local governments did not use the (admittedly limited) policy tools at their disposal to combat expected increases in local crime rates from police station closures and support local law enforcement of the state police in their jurisdiction. This is, however, in line with the null effects on crime rates in broad crime categories from station closures and widely absent changes in detection rates. In the long-run municipalities even decrease public safety and law and order spending which may reinforce increasing theft in several categories (e.g. cars or apartment burglary). 


\subsection{Crime displacement from police reorganization}

Another explanation for the observed changes in criminal activity could be crime displacement from enlarged police stations towards towns that underwent station closures. To address this point, we run our estimations using the 122 municipalities that receive new police officers from the closing nearby police stations. Since we know the exact merger constellations, we know which police stations and localities receive extra staff in the course of the merger wave. As before, we use event-study models on a sample of matched treatment and control municipalities to make causal inference of increased/received police staff and an increase in physical presence of police forces on local crime in the affected municipalities 33

This type of analysis can also be seen as a test of how crime deterrence may have changed due to police reorganization. In case of receiving municipalities, i.e. towns which receive police staff at the expense of closing police stations in nearby localities, salience or visibility of local police forces did not increase significantly as additional police forces were usually integrated into existing buildings. However, physical presence of police forces per unit of time should have increased in these municipalities. For instance, opening hours increased by $7.5 \%$ on average for all remaining police stations according to Landtag Baden-Wuerttemberg 2005) 34

Now we consider the respective effects on the enlarged stations on the number of reported crimes in total as well as across broader (see Figure OA-D.1) and detailed theft crime categories (see Figure E.5) ${ }^{35}$ The results suggest that additional police forces did not affect criminal activity in the affected municipalities. Interestingly, we do not see a significant decrease in reported crimes in the categories considered. Thus, changing patterns in theft activity in closure municipalities cannot be explained by a displacement of criminal activity from towns with enlarged stations towards closure municipalities.

This suggests that changes in theft in closure municipalities are due to responses of criminal offenders in these municipalities but not due to spillover effects from other enlarged stations. Moreover, we also do not observe that enlarged stations improve their detection rates systematically across crime categories despite their new staff. This is illustrated in Figure OA-D.4 of the Online Appendix. However, the catchment area for

\footnotetext{
${ }^{33}$ See Table E.1 for the quality of matches between treatment and control municipalities. Again, our matching variables are very similar across comparison groups, but a few variables differ in this specification. Specifically, skill levels and participation in active labor market programs are somewhat higher in the control units while the related differences are significant at conventional levels.

${ }^{34}$ Unfortunately, we do not have information on deployment protocols of police forces or (effective) opening hours of stations to quantify changes in actual presence of police forces across jurisdictions.

${ }^{35}$ While Online Appendix Table OA-D.1 gives the difference-in-difference results for the aggregate crime categories, Tables OA-D.2 and OA-D.3 depict related results for the subcategories of crime against life, sex crimes and robbery. Again, related crime effects of enlargement of police stations are widely absent across crime categories.
} 
which these stations are responsible after the reform is also increasing substantially and accordingly, distances become larger.

\subsection{Changes in distance to nearest police station}

The results thus far suggest that crime effects from station closures are driven by a decrease in deterrence and less salient policing in the respective localities. We now test whether or not the change in distance to the nearest police station matters for effects of station closures on crime rates (Blanes i Vidal and Kirchmaier, 2015). This is also linked to deterrence, as a higher response times of police forces would be associated with lower deterrence levels, thus leading to stronger responses of crime rates ${ }^{36}$ Note that as our baseline estimations focus on closure events in municipalities which lose their last station, a closure event always increases the distance to the nearest station in any case. Hence, driving distance and the visibility of local police forces become affected in closure municipalities. The change in distance through police station closures to the nearest station varies between $2.2 \mathrm{~km}$ to $13 \mathrm{~km}$ with an average change in distance of $6 \mathrm{~km}$.

Table E.2 provides difference-in-differences estimates for sub-samples where changes of distance are below average (Panel A) and above average distance of $6 \mathrm{~km}$ (Panel B). In line with the interpretation of lower deterrence, the table shows that our baseline effects on detailed theft crimes are driven by municipalities with relatively larger distances. All effects with low changes of distance become insignificant and point estimates as well as significance levels increase substantially for larger distances across theft categories.

\subsection{Composition effects on criminal suspects}

At last, we also ask who is reacting to police station closures. To answer this, we analyze the characteristics of suspects, i.e. the so called Tatverdächtigenstatistik from the State Criminal Office. We know the total number of suspects per crime category, the number of suspects by gender, nationality (german/non-german) and age groups (youth suspects aged $<18$, suspects aged $18-21$ as well as adults aged $>21$ ) per municipality and year.

Again, we focus our analysis on theft crimes. At this stage it should be noted that suspects are not necessarily criminals from a legal point of view. The suspects statistics have the advantage of no double counting. If a person, for example, steals a car and a bicycle, he/she would be counted for each category but only once for all theft crimes.

\footnotetext{
${ }^{36}$ Unfortunately, we do not have exact driving distances available due to the lack of geocoded locations of crime scenes and police stations to estimate elasticities of driving distance for police staff on crime (Blanes i Vidal and Kirchmaier, 2015). We measure distances as geographical minimum distances of municipal centroids to the nearest available police station.
} 
The empirical strategy to analyze a potential change in the composition of the pool of criminals/suspects is twofold. We first seek to answer the question of whether or not the reform induced non-criminals to engage in theft crime. For that, we regress the total (log) number of suspects on the reform indicator, using the difference-in-difference approach for total theft. We also estimate whether closures lead to a change in the number of suspects per reported case for total theft. Intuitively, if prior non-criminals are engaging in theft crime after station closures, we would expect an increase in the number of suspects. Second, we regress, similar to our empirical strategy above, the log number of suspects by socio-demographic characteristics in each detailed theft crime category (car, moped and bicycle theft plus apartment and basement burglary) on the reform dummy.

Table E.3 reports the results for the total number of suspects and the number of suspects per case for overall theft. The point estimates of the station closures are both close to zero and insignificant. This provides indirect evidence that the reform does not, on average, induce non-criminals to become thieves. Moreover, analyzing changes in the number of suspects per case might detect new suspects who act, for example, with already existing criminals. Thus, if new criminals are engaging in crime with others, one would expect an increase in the number of suspects per crime case. Again, the lack of effects indicates that changes in the reported theft crimes is likely driven by already active criminals.

Table E.4 reports the results for detailed theft categories. Panel A shows the results for all suspects. In line with the findings on reported cases, we find that the number of suspects for car and moped theft increased significantly after station closures. We also observe a reduction in the number of suspects for bicycle theft. Surprisingly, there are no significant changes in the number of suspects for burglary which is indirect evidence that in burglary the same number of criminals performs more crimes per person. This is different for other theft categories, where station closures lead to a similar change in the number of reported crime cases and the number of relevant suspects. Altogether, we can observe changes in the composition of criminal suspects although the total number of suspects for theft in general does not change in response to police station closures.

Panels B to F of Table E.4 show the results by socio-demographic characteristics of suspects. Effects are driven by German males. These males are both young (in case of moped theft and burglary) and adults (in case of car theft), whereas individuals between 18 and 21 years of age do not react significantly to station closures. 


\section{Concluding remarks}

This paper provides novel evidence on the effects of police station closures on crime using a quasi-experiment in a large German state. We use hundreds of police station closures - which did not lead to layoffs but reallocated local police officers to other stations to identify crime effects in a combination of matching and event-study models. Using detailed criminal records on the municipal level, we do not find that total theft increases but show that closures result in significant changes in the way theft crimes are conducted. We observe strong increases in car theft, moped theft and burglary which is line with earlier evidence of police force reallocation. Bicycles, however, are stolen significantly less.

Crime deterrence plays a large role in our setting (Nagin, 2013; Chalfin and McCrary, $2017 b$ ). We argue that potential offenders perceive the salient policy change of station closures, expect police presence to decrease given that the distances to other stations increases and choose to shift activities from bicycle theft towards more valuable activities, e.g. car theft. However, we do not find evidence for effects of police station closures on total crime rates, on crimes against life or on sexual assault. Also detection rates do not change in response to station closures which rules out incapacitation of local police forces as a main explanation for our findings. Instead, police closures act as a salient negative shock to the perceived quality of local law enforcement due to larger distances to other stations, albeit actual police efficiency is unchanged. Indeed, larger distances to nearby police stations are an important driver of our results. We also find that station closures do not encourage more people to become criminal but show instead that already active criminals shift their focus from low end goods, like bicycles, towards more valuable goods.

Hence, reallocating local police forces via station closures might not necessarily incur efficiency losses in law enforcement but gives rise to behavioral reactions of local criminals through reduced crime deterrence. Our estimates provide a lower bound on increases of street-crime since no layoffs of local police forces were implemented. Often, however, police closures may come at the cost of a reduction in the number of local police officers in order to increase fiscal flexibility. Decreasing manpower would, however, likely add to criminal activity and reduce efficiency (Chalfin and McCrary, 2017a; Fu and Wolpin, forthcoming).

Regarding the external validity of our findings, the following remarks must be made. Most of our identifying variation comes from relatively rural places since we focus on municipalities losing their last police station as in contrast to larger cities where several stations might be available. Losing a police station may not be as salient in a town where several other stations continue to exist which can compensate any negative effects from 
closures. Hence, we only expect our effects to be valid for other rural settings but cannot necessarily extend our findings to more urban settings. Street-crime in urban areas, however, is rather related to intense social interactions (Glaeser et al., 1996).

Future research may highlight the role of other administrative reforms such as redistricting local police wards for criminal activity and the efficiency of local police forces. One may also observe different crime effects from the creation of new police stations (or longer opening hours) as for closures of police stations which were the focus of this paper.

\section{References}

Aargauer Zeitung (2017), 'Reorganisation der Kantonspolizei', URL: https: //www.ag.ch/de/weiteres/aktuelles/medienportal/medienmitteilung/ medienmitteilungen/mediendetails_79698.jsp.

Amtsblatt Eichstetten - Eichstetter Nachrichten (2004), 'Innenministerium gibt grünes Licht für Optimierung der Polizeipostenstruktur'.

Apel, R. (2013), 'Sanctions, perceptions, and crime: Implications for criminal deterrence', Journal of Quantitative Criminology 29(1), 67-101.

Audit Court Baden-Wuerttemberg (2002), 'Organisation und Personaleinsatz beim Polizeipräsidium Mannheim können verbessert werden', URL: https : //www.rechnungshof .baden-wuerttemberg.de/de/informationen/presse/ 272915.html.

Bayley, D. H. (1996), Police for the Future, Oxford University Press on Demand.

Becker, G. S. (1968), Crime and punishment: An economic approach, in 'The Economic Dimensions of Crime', Springer, pp. 13-68.

Bell, B., Fasani, F. and Machin, S. (2013), 'Crime and immigration: Evidence from large immigrant waves', Review of Economics and statistics 21(3), 1278-1290.

Bertrand, M., Duflo, E. and Mullainathan, S. (2004), 'How much should we trust differences-in-differences estimates?', Quarterly Journal of Economics 119(1), 249274.

Blanes i Vidal, J. and Kirchmaier, T. (2015), 'The effect of police response time on crime clearance rates', The Review of Economic Studies 85(2), 855-891.

Blanes i Vidal, J. and Mastrobuoni, G. (2017), 'Police patrols and crime'. 
Blattman, C., Green, D., Ortega, D. and Tobón, S. (2017), Pushing crime around the corner? estimating experimental impacts of large-scale security interventions, Technical report, National Bureau of Economic Research.

Blattman, C., Jamison, J. and Sheridan, M. (2017), 'Reducing crime and violence: Experimental evidence on adult noncognitive investments in liberia', American Economic Review 107(4), 1165-1206.

Boatca, M. (2004), 'Entzauberte Männlichkeit: Geschlechtsidentitäten in der brüchigen Moderne', Kriminologisches Journal 36(3), 197-211.

Braga, A. A., Papachristos, A. V. and Hureau, D. M. (2014), 'The effects of hot spots policing on crime: An updated systematic review and meta-analysis', Justice Quarterly 31(4), 633-663.

Bundesministerium des Inneren (2017), 'Bericht zur Polizeilichen Kriminalstatistik 2016', https://www.bmi.bund.de/SharedDocs/downloads/ DE/publikationen/themen/sicherheit/pks-2016.pdf?_-_blob= publicationFile\&v=5 (20.04.2018). Bundesministerium des Inneren.

Bundesministerium für Inneres (2014), 'Zwischenstand im INNEN.SICHER.Projekt "Moderne Polizei", URL: http://bmi.gv.at/news.aspx?id= 665662645752652B5548673D,

Card, D. and Dahl, G. B. (2011), 'Family Violence and Football: The Effect of Unexpected Emotional Cues on Violent Behavior', Quarterly Journal of Economics 126(1), 103-143.

Chalfin, A. and McCrary, J. (2017a), 'Are US cities underpoliced? Theory and evidence', Review of Economics and Statistics 100(1), 167-186.

Chalfin, A. and McCrary, J. (2017b), 'Criminal deterrence: A review of the literature', Journal of Economic Literature 55(1), 5-48.

Cortes, G. M. and Gallipoli, G. (2018), 'The costs of occupational mobility: An aggregate analysis', Journal of the European Economic Association 16(2), 275-315.

Di Tella, R. and Schargrodsky, E. (2004), 'Do police reduce crime? estimates using the allocation of police forces after a terrorist attack', American Economic Review 94(1), 115-133.

Draca, M., Koutmeridis, T. and Machin, S. (forthcoming), 'The changing returns to crime: do criminals respond to prices?', The Review of Economic Studies . 
Draca, M., Machin, S. and Witt, R. (2011), 'Panic on the Streets of London: Police, Crime, and the July 2005 Terror Attacks', The American Economic Review 101(5), 2157-2181.

Ehrlich, I. (1974), Participation in Illegitimate Activities: An Economic Analysis, in 'Essays in the Economics of Crime and Punishment', NBER, pp. 68-134.

Entorf, H. and Spengler, H. (2000), 'Socioeconomic and demographic factors of crime in Germany: Evidence from panel data of the German states', International Review of Law and Economics 20(1), 75-106.

Eurostat (2018), 'Crime and criminal justice database', http://ec.europa.eu/ eurostat/web/crime/database (20.06.2013).

Evans, W. N. and Owens, E. G. (2007), 'Cops and crime', Journal of Public Economics 91(1), 181-201.

Freeman, R. B. (1999), 'The economics of crime', Handbook of Labor Economics 3c, 3529-3571.

Fu, C. and Wolpin, K. I. (forthcoming), 'Structural Estimation of a Becker-Ehrlich Equilibrium Model of Crime: Allocating Police Across Cities to Reduce Crime', Review of Economic Studies .

Fyfe, N. R., Terpstra, J. and Tops, P. (2013), Centralizing forces? Comparative perspectives on contemporary police reform in northern and Western Europe, The Hague: Eleven International Publishing.

Gäubote (2003), 'Die Ortskenntnis ist ermittlungstaktisch wichtig', URL: https://www.gaeubote.de/gb_10_107178629-24-_ quotDie-Ortskenntnis-ist-ermittlungstaktisch-wichtigquot.html? archiv=1.

Glaeser, E. L., Sacerdote, B. and Scheinkman, J. A. (1996), 'Crime and social interactions', The Quarterly Journal of Economics 111(2), 507-548.

Haraholma, K. and Houtsonen, J. (2013), 'Restructuring the finnish police administration', Centralizing forces pp. 59-76.

Heaton, P., Hunt, P., MacDonald, J. and Saunders, J. (2016), 'The short-and long-run effects of private law enforcement: Evidence from university police', The Journal of Law and Economics 59(4), 889-912. 
Heller, S. B., Shah, A. K., Guryan, J., Ludwig, J., Mullainathan, S. and Pollack, H. A. (2017), 'Thinking, fast and slow? some field experiments to reduce crime and dropout in chicago', The Quarterly Journal of Economics 132(1), 1-54.

Innenministerium Baden-Wuerttemberg (2012a), 'Polizeistrukturreform BadenWuerttemberg - Abschlussbericht'. Innenministerium Baden-Wuerttemberg.

Innenministerium Baden-Wuerttemberg (2012b), 'Struktur der Polizei BadenWuerttemberg - Eckpunkte'. Innenministerium Baden-Wuerttemberg.

Kaiser, G. (1996), Kriminologie: ein Lehrbuch, CF Müller GmbH.

Kennedy, D. M., Braga, A. A., Piehl, A. M. and Waring, E. J. (2001), Reducing gun violence: the boston gun project's operation ceasefire, US Department of Justice Office of Justice Programs.

Kleck, G. and Barnes, J. (2014), 'Do more Police lead to more Crime Deterrence?', Crime \& Delinquency 60(5), 716-738.

Kleck, G., Sever, B., Li, S. and Gertz, M. (2005), 'The Missing Link in General Deterrence Research', Criminology 43(3), 623-660.

Klick, J. and Tabarrok, A. (2005), 'Using Terror Alert Levels to Estimate the Effect of Police on Crime', The Journal of Law and Economics 48(1), 267-279.

Kubrin, C. E., Messner, S. F., Deane, G., McGeever, K. and Stucky, T. D. (2010), 'Proactive policing and robbery rates across us cities', Criminology 48(1), 57-97.

Landtag Baden-Wuerttemberg (2003), 'Neuordnung der Posten- und Revierstruktur der Polizei'. Landtag Baden-Wuerttemberg.

Landtag Baden-Wuerttemberg (2004), 'Veränderung der Revier- und Postenstruktur bei der Polizei in Baden-Baden-Wuerttemberg'. Landtag Baden-Wuerttemberg.

Landtag Baden-Wuerttemberg (2005), 'Polizeipräsenz in der Fläche - Erfahrungen mit der neuen Struktur der Polizeiposten'. Landtag Baden-Wuerttemberg.

Lee, D. S. and McCrary, J. (2017), 'The Deterrence Effect of Prison: Dynamic Theory and Evidence', Advances in Econometrics 38, 73-146.

Lemieux, T., Fortin, B. and Frechette, P. (1994), 'The Effect of Taxes on Labor Supply in the Underground Economy', The American Economic Review pp. 231-254. 
Levitt, S. D. (1997), 'Using Electoral Cycles in Police hiring to Estimate the Effects of Police on Crime', The American Economic Review 92(4), 1244-1250.

Lin, M.-J. (2009), 'More police, less crime: Evidence from US state data', International Review of Law and Economics 29(2), 73-80.

MacDonald, J. M., Klick, J. and Grunwald, B. (2016), 'The effect of private police on crime: evidence from a geographic regression discontinuity design', Journal of the Royal Statistical Society: Series A (Statistics in Society) 179(3), 831-846.

Machin, S. and Meghir, C. (2004), 'Crime and economic incentives', Journal of Human Resources 39(4), 958-979.

Maher, C. S. (2015), 'A longitudinal analysis of the effects of service consolidation on local government expenditures', Public Administration Quarterly pp. 393-425.

Mendel, J., Fyfe, N. R. and den Heyer, G. (2017), 'Does police size matter? a review of the evidence regarding restructuring police organisations', Police Practice and Research 18(1), 3-14.

Metropolitan Police (2016), 'Modernising the Metropolitan Police Service', URL: http://news.met.police.uk/news/ modernising-the-metropolitan-police-service-199312.

Nagin, D. S. (2013), 'Deterrence in the twenty-first century', Crime and Justice 42(1), 199-263.

New Zealand Parliament (2017), 'Police ResourcingâĂŤPolice Stations and Community Policing', URL: https://www.parliament.nz/en/ $\mathrm{pb} / \mathrm{hansard}$-debates/rhr/document/HansS_20170802_051750000/ 4-police-resourcing-police-stations-and-community-policing.

Oberschachtsiek, D., Scioch, P., Seysen, C. and Heining, J. (2008), 'Stichprobe der Integrierten Erwerbsbiografien'. Handbuch für die IEBS in der Fassung.

Pei, Z., Pischke, J.-S. and Schwandt, H. (2017), Poorly measured confounders are more useful on the left than on the right, Technical report, National Bureau of Economic Research.

Poutvaara, P. and Priks, M. (2009), 'The effect of police intelligence on group violence: Evidence from reassignments in sweden', Journal of Public Economics 93(3-4), 403411. 
Schwäbische Zeitung (2004), 'Drei Posten bleiben übrig', URL: https://www . schwaebische.de/home_artikel,__arid, 1042761.html

Schwäbische Zeitung (2006), 'Polizisten ziehen nach Dornstadt um', URL: https:// WWw.schwaebische.de/home_artikel,__arid, 1831871.html.

Sherman, L. W., Gottfredson, D. C., MacKenzie, D. L., Eck, J., Reuter, P., Bushway, S. et al. (1997), Preventing crime: What works, what doesn't, what's promising: A report to the United States Congress, US Department of Justice, Office of Justice Programs Washington, DC.

Shi, L. (2009), 'The limit of oversight in policing: Evidence from the 2001 cincinnati riot', Journal of Public Economics 93(1-2), 99-113.

Simper, R. and Weyman-Jones, T. (2008), 'Evaluating gains from mergers in a nonparametric public good model of police services', Annals of Public and Cooperative Economics 79(1), 3-33.

Steinmauern Gemeindeanzeiger (2012), 'Optimierung der Polizeipostenstruktur - Arbeitsgruppe legt Ergebnis vor, Ziel war Optimierung mit Augenmaß', URL: http: //www.steinmauern.de/nc/aktuelles/gemeindeanzeiger-archiv/archiv/7. 48.1.8/7B8EB8AD5097C25CC1256E280066CFBD.html.

Stuart, E. A. and Rubin, D. B. (2008), 'Best practices in quasi-experimental designs', Best Practices in Quantitative Methods pp. 155-176.

Stuttgarter Nachrichten (2009), 'Stellenabbau bei der Polizei - Wir gehen auf dem Zahnfleisch', URL: https://www.stuttgarter-nachrichten.de/inhalt. stellenabbau-bei-der-polizei-wir-gehen-auf-dem-zahnfleisch . 8a692dc2-522f-4c12-96fb-c91eef1e5e79.html.

US Department of Justice (2011), Census of State and Local Law Enforcement Agencies, 2008, Technical report. https://www.bjs.gov/content/pub/pdf/csllea08.pdf.

US Department of Justice (2015), Census of State and Local Law Enforcement Agencies, 2013, Technical report. https://www.bjs.gov/content/pub/pdf/lpd13ppp.pdf.

Vereniging van Vlaamse Steden en Gemeenten (2017), 'Stand van zaken van fusies bij lokale politiezones', URL: http://www.vvsg.be/veiligheid/lokalepolitie/ Documents $/ \mathrm{KVH} \% 20 \mathrm{~d} 805$ nota\%20fusies\%20van\%20politiezones.pdf\#search= fusie\%20politiezones 
Walter, M. (2008), Gewaltkriminalität, Erscheinungsformen - Entstehungsbedingungen - Antworten, Rechtswissenschaften heute, Stuttgart.

Weisburd, S. (2016), 'Police presence, rapid response rates, and crime prevention', Unpublished Working Paper. 


\section{Appendix}

\section{A Background information and summary statistics}

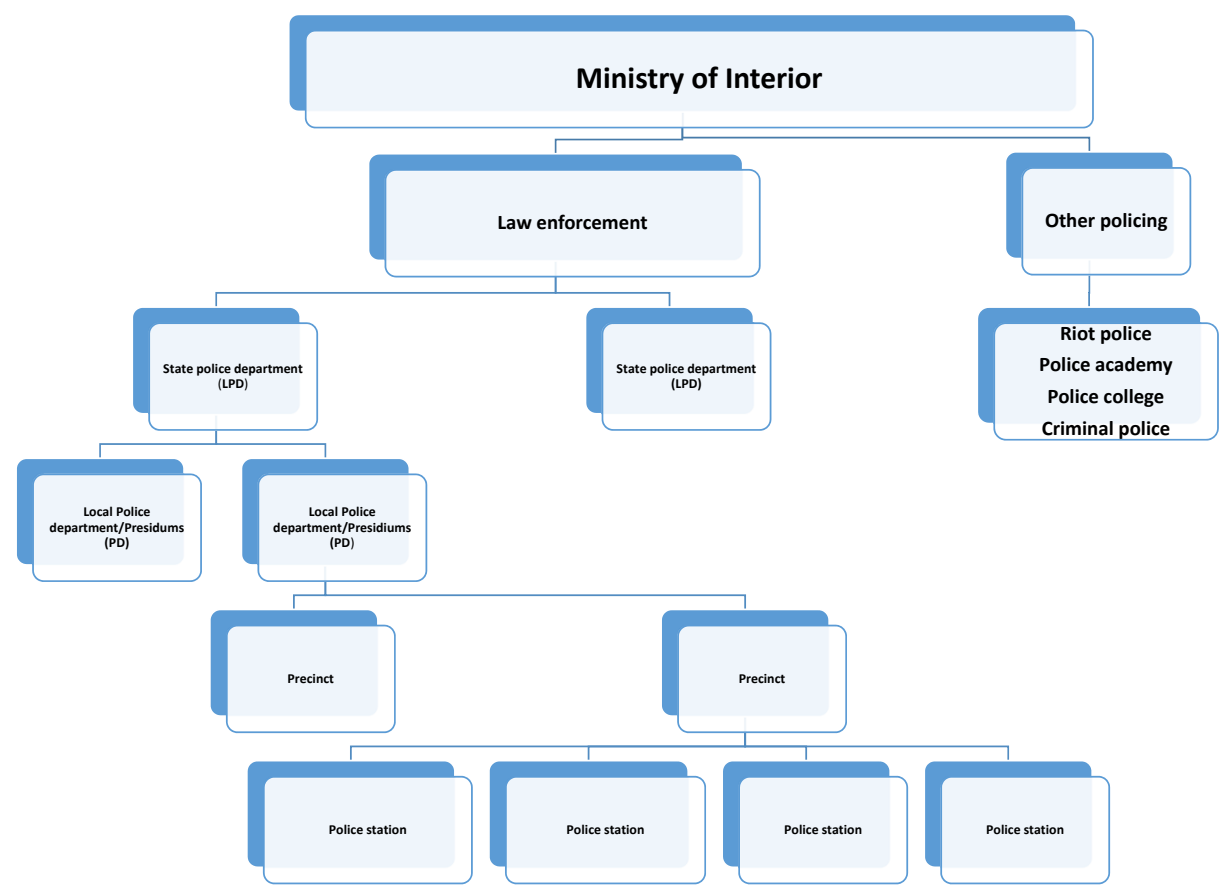

Notes: The figure shows the organization and structure of the local law enforcement in Baden-Wuerttemberg. Source: Own compilation based on Innenministerium Baden-Wuerttemberg [2012a].

Figure A.1: Organization of local law enforcement in Baden-Wuerttemberg in 2011 


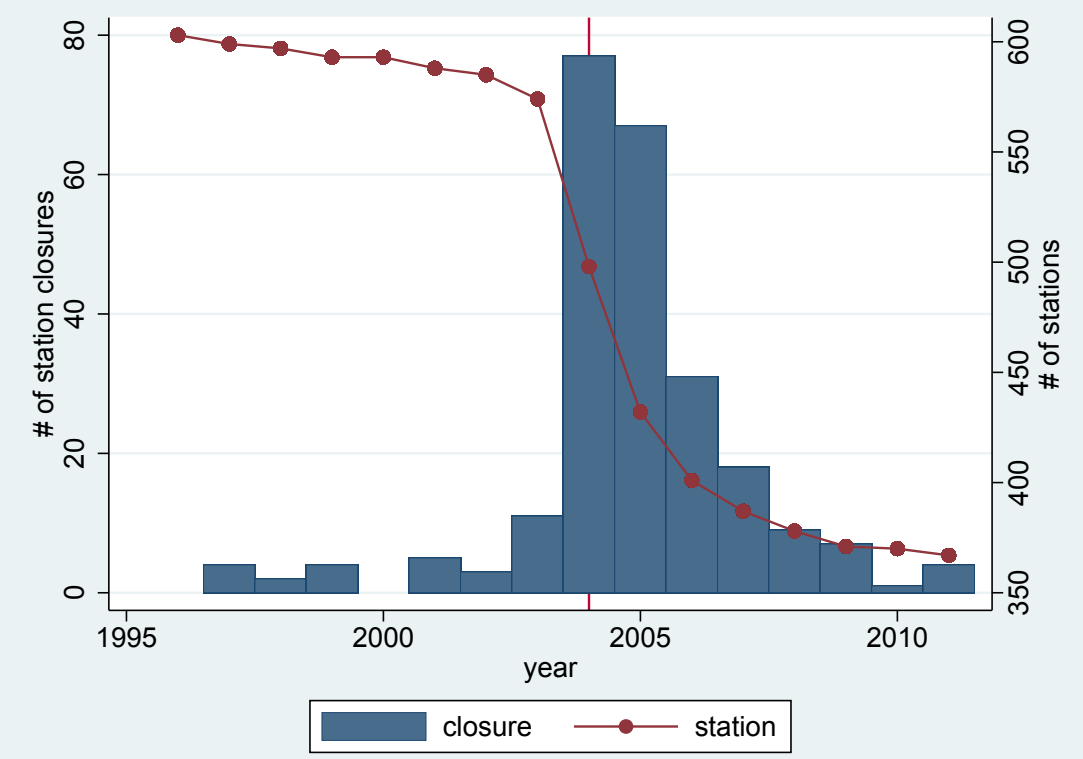

Notes: The figure plots the number of police stations closures (left axis) over the time period between 1995 and 2011. Over the time period, we observe 235 closing events in total. The red line (right axis) shows the total number of police stations end of year.

Figure A.2: Number of stations and timing of station closures 

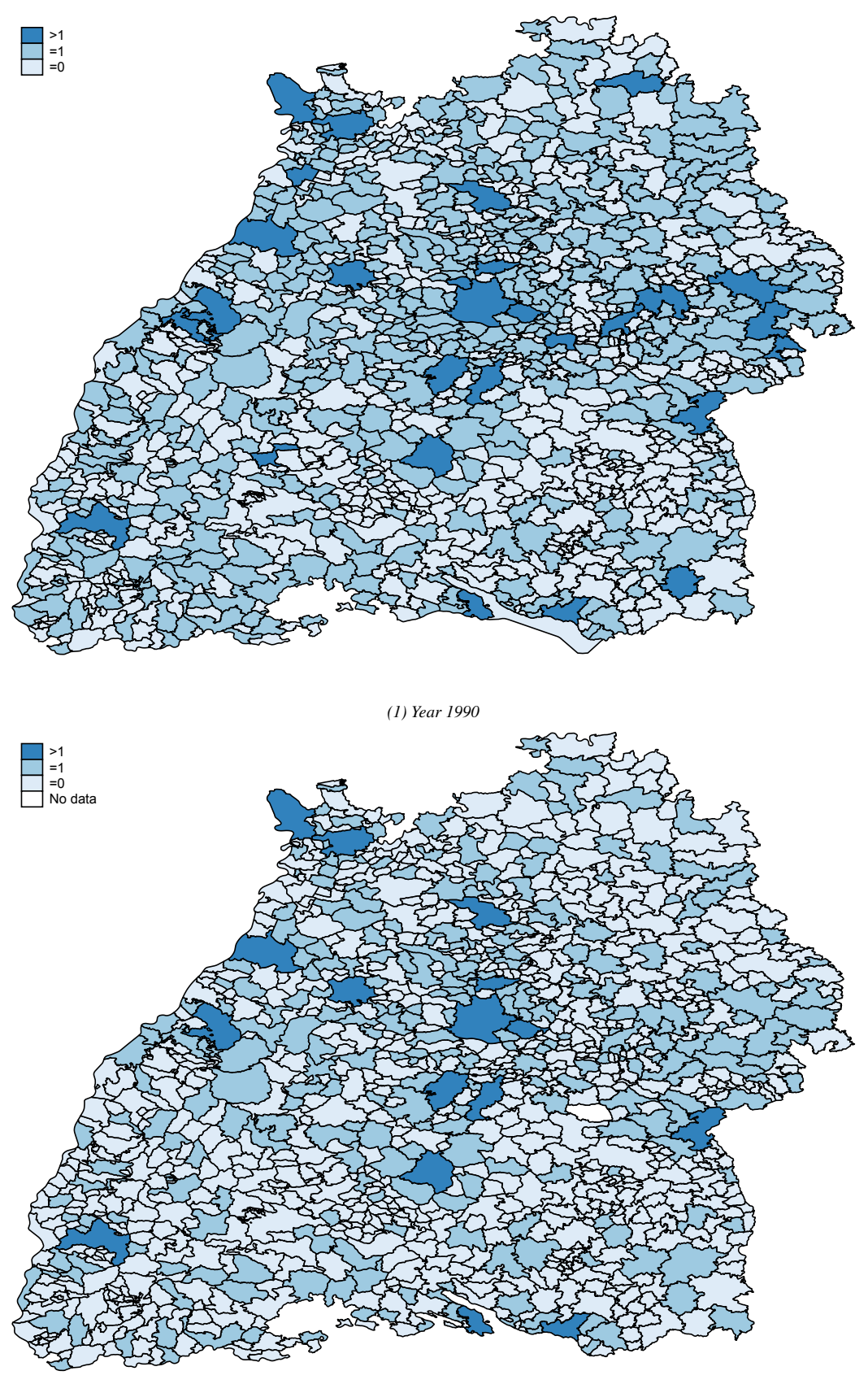

(2) Year 2011

Notes: The figure plots the number of police stations for every municipality for the year 1990 and 2011 . The dark blue color indicates the presence of more than 1 police station in a given municipality. Light blue indicates the presence of 1 police station and white municipalities do not have any police station.

Figure A.3: Allocation police stations over time 
Table A.1: Summary statistics on key crime categories

\begin{tabular}{|c|c|c|c|c|c|}
\hline & Mean & $\begin{array}{l}\text { Standard } \\
\text { deviation }\end{array}$ & Minimum & Maximum & $\mathrm{N}$ \\
\hline \multicolumn{6}{|c|}{ Panel A: Reported crime cases } \\
\hline Total & 527.86 & 2478.90 & 0 & 62,071 & 17,528 \\
\hline Crime against life & 0.34 & 1.54 & 0 & 48 & 17,528 \\
\hline Sex crime & 5.06 & 22.47 & 0 & 661 & 17,528 \\
\hline Robbery & 54.97 & 267.72 & 0 & 8,938 & 17,528 \\
\hline Theft & 215.37 & 1010.59 & 0 & 2,5407 & 17,528 \\
\hline \multicolumn{6}{|l|}{ Theft subcategories } \\
\hline Car theft & 2.82 & 13.21 & 0 & 387 & 17,528 \\
\hline Moped theft & 3.82 & 22.23 & 0 & 809 & 17,528 \\
\hline Bicycle theft & 26.74 & 128.29 & 0 & 2718 & 17,528 \\
\hline Apartment burglary & 11.66 & 55.13 & 0 & 1517 & 17,528 \\
\hline Basement burglary & 4.12 & 27.38 & 0 & 673 & 17,528 \\
\hline \multicolumn{6}{|c|}{ Panel B: Detection rates } \\
\hline Total & 0.576 & 0.147 & 0 & 6.8 & 17,488 \\
\hline Crime against life & 0.962 & 0.199 & 0 & 2.5 & 2,961 \\
\hline Sex crime & 0.809 & 0.315 & 0 & 5.5 & 11,611 \\
\hline Robbery & 0.922 & 0.120 & 0 & 5.0 & 16,811 \\
\hline Theft & 0.279 & 0.180 & 0 & 4.9 & 17262 \\
\hline \multicolumn{6}{|l|}{ Theft subcategories } \\
\hline Car theft & 0.444 & 0.480 & 0 & 15.0 & 8,610 \\
\hline Moped theft & 0.249 & 0.364 & 0 & 6.0 & 8,875 \\
\hline Bicycle theft & 0.088 & 0.191 & 0 & 3.0 & 13,416 \\
\hline Apartment burglary & 0.341 & 0.501 & 0 & 43 & 14,368 \\
\hline Basement burglary & 0.216 & 0.368 & 0 & 8 & 7,082 \\
\hline \multicolumn{6}{|c|}{ Panel C: Resulting damage (Euro/case) } \\
\hline Total & $1,576.9$ & $5,073.9$ & 0 & $207,810.5$ & 9,830 \\
\hline Crime against life & 63.65 & $1,635.63$ & 0 & $54,945.05$ & 1,573 \\
\hline Sex crime & - & - & - & - & - \\
\hline Robbery & 129.59 & $2,132.57$ & 0 & $132,787.4$ & 9,503 \\
\hline Theft & 953.84 & $1,790.18$ & 0 & $66,937.12$ & 9,720 \\
\hline \multicolumn{6}{|l|}{ Theft subcategories } \\
\hline Car theft & $7,114.09$ & $14,217.21$ & 0 & $253,549.7$ & 4,358 \\
\hline Moped theft & $1,227.84$ & $2,917.35$ & 0 & 80,250 & 5,028 \\
\hline Bicycle theft & 372.46 & 734.98 & 0 & $37,837.84$ & 7,708 \\
\hline Apartment burglary & $2,134.46$ & $7,599.75$ & 0 & 250,725 & 8,059 \\
\hline Basement burglary & 473.58 & $2,024.11$ & 0 & 75,815 & 3,911 \\
\hline
\end{tabular}




\section{B Matching approach}

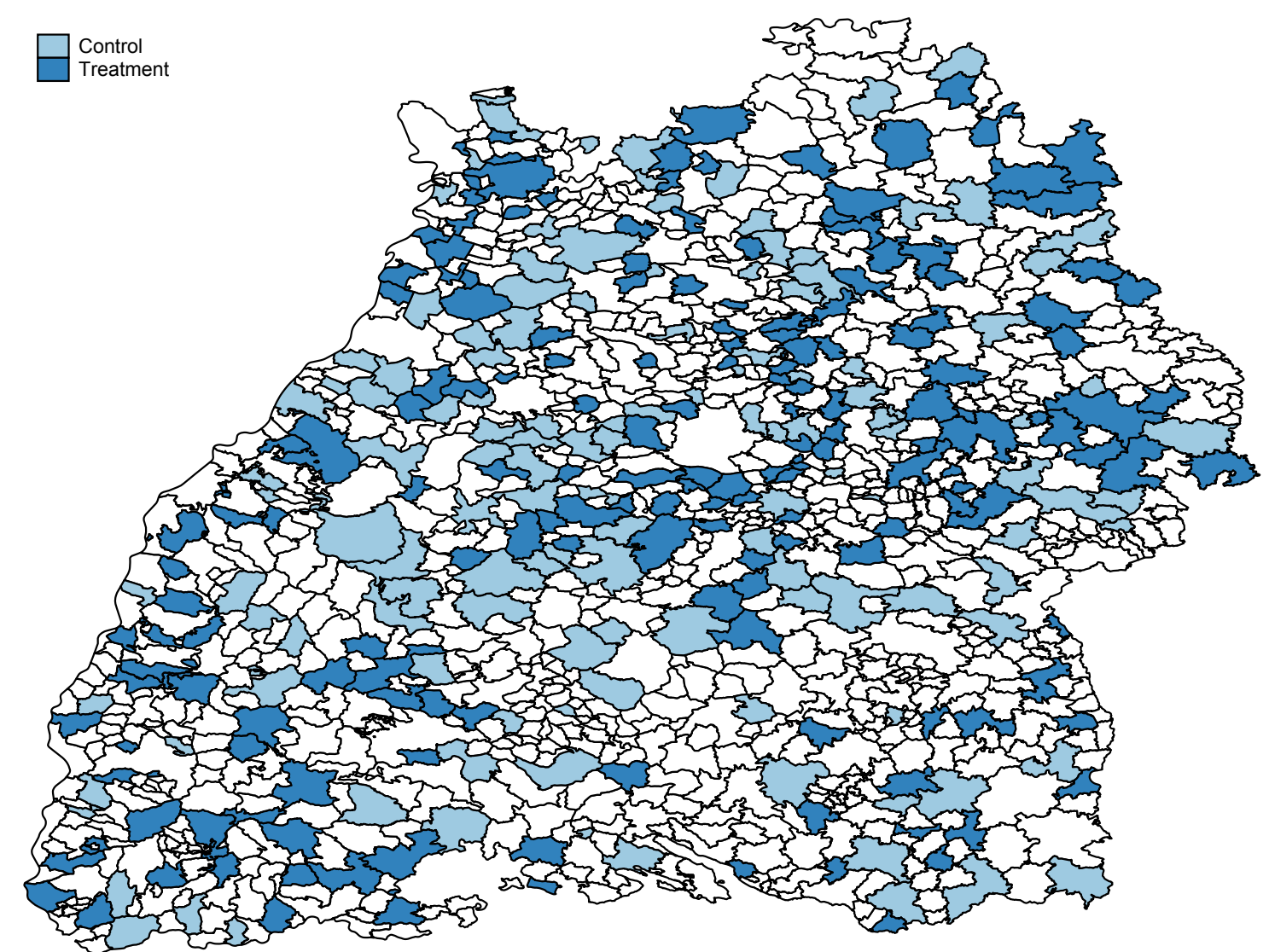

Notes: The figure shows the spatial allocation of treated and control municipalities in the Federal State of Baden-Wuerttemberg. Treated municipalities are municipalities with a police station closure between 1990 and 2011.

Figure B.1: Location of treated and matched control municipalities 
Table B.1: Treated vs control municipalities

\begin{tabular}{|c|c|c|c|c|c|}
\hline & $\begin{array}{c}\text { Treated } \\
(1)\end{array}$ & $\begin{array}{c}\text { Control } \\
(2)\end{array}$ & $\begin{array}{c}p \text {-value } \\
(3)\end{array}$ & $\begin{array}{c}\text { All municipalities } \\
(4)\end{array}$ & $\begin{array}{c}p \text {-value } \\
(5)\end{array}$ \\
\hline \multicolumn{6}{|c|}{ Panel A: 1 year before treatment $\tau=-1$} \\
\hline Population share $<15$ & 0.169 & 0.168 & 0.695 & 0.170 & 0.550 \\
\hline Population share $>65$ & 0.174 & 0.172 & 0.370 & 0.173 & 0.657 \\
\hline Unskilled & 0.177 & 0.186 & 0.184 & 0.195 & 0.012 \\
\hline Skilled & 0.726 & 0.722 & 0.615 & 0.715 & 0.184 \\
\hline High-skilled & 0.097 & 0.092 & 0.340 & 0.090 & 0.190 \\
\hline Female & 0.466 & 0.470 & 0.622 & 0.471 & 0.574 \\
\hline Foreigners & 0.079 & 0.082 & 0.565 & 0.070 & 0.065 \\
\hline \multicolumn{6}{|l|}{ Labor market indicators } \\
\hline Real daily wage & 121.498 & 120.467 & 0.685 & 118.069 & 0.110 \\
\hline Unemployment rate & 0.022 & 0.022 & 0.467 & 0.016 & 0.000 \\
\hline ALMP & 0.008 & 0.008 & 0.929 & 0.007 & 0.412 \\
\hline \multicolumn{6}{|l|}{ Occupational structure } \\
\hline$\overline{\text { Agriculture }}$ & 0.013 & 0.010 & 0.126 & 0.014 & 0.573 \\
\hline Production & 0.310 & 0.317 & 0.504 & 0.317 & 0.491 \\
\hline Salary & 0.138 & 0.136 & 0.717 & 0.137 & 0.953 \\
\hline Sale & 0.064 & 0.060 & 0.396 & 0.065 & 0.737 \\
\hline Clerical & 0.244 & 0.245 & 0.936 & 0.234 & 0.187 \\
\hline Service & 0.231 & 0.231 & 0.983 & 0.232 & 0.957 \\
\hline \multicolumn{6}{|l|}{ Revenuelexpenditure } \\
\hline$\overline{\text { Income tax revenue }}$ & 319.682 & 323.870 & 0.497 & 318.883 & 0.863 \\
\hline Commercial tax revenue & 284.350 & 241.496 & 0.210 & 303.409 & 0.573 \\
\hline Public safety expenditures & 52.523 & 54.628 & 0.612 & 53.277 & 0.800 \\
\hline Law and order expenditures & 17.942 & 21.090 & 0.066 & 17.856 & 0.954 \\
\hline Public deficit & -20.562 & -6.954 & 0.510 & -2.748 & 0.053 \\
\hline \multicolumn{6}{|c|}{ Panel B: 4 years before treatment $\tau=-4$} \\
\hline \multicolumn{6}{|c|}{ Demographics } \\
\hline Population share $<15$ & 0.179 & 0.178 & 0.650 & 0.181 & 0.246 \\
\hline Population share $>65$ & 0.158 & 0.156 & 0.485 & 0.158 & 0.925 \\
\hline Unskilled & 0.192 & 0.203 & 0.108 & 0.203 & 0.108 \\
\hline Skilled & 0.721 & 0.713 & 0.278 & 0.710 & 0.204 \\
\hline High-skilled & 0.088 & 0.084 & 0.548 & 0.084 & 0.474 \\
\hline Female & 0.467 & 0.465 & 0.862 & 0.467 & 0.969 \\
\hline Foreigners & 0.080 & 0.084 & 0.494 & 0.070 & 0.046 \\
\hline \multicolumn{6}{|l|}{ Labor market indicators } \\
\hline$\overline{\text { Real daily wage }}$ & 121.467 & 120.981 & 0.837 & 118.961 & 0.228 \\
\hline Unemployment rate & 0.020 & 0.021 & 0.201 & 0.022 & 0.004 \\
\hline ALMP & 0.005 & 0.005 & 0.952 & 0.005 & 0.515 \\
\hline \multicolumn{6}{|l|}{ Occupational structure } \\
\hline$\overline{\text { Agriculture }}$ & 0.013 & 0.011 & 0.360 & 0.015 & 0.496 \\
\hline Production & 0.326 & 0.336 & 0.358 & 0.336 & 0.358 \\
\hline Salary & 0.131 & 0.126 & 0.438 & 0.131 & 0.916 \\
\hline Sale & 0.063 & 0.060 & 0.428 & 0.063 & 0.950 \\
\hline Clerical & 0.239 & 0.242 & 0.683 & 0.234 & 0.562 \\
\hline Service & 0.228 & 0.224 & 0.616 & 0.227 & 0.884 \\
\hline \multicolumn{6}{|l|}{ Revenuelexpenditure } \\
\hline Income tax revenue & 350.210 & 354.180 & 0.527 & 330.129 & 0.000 \\
\hline Commercial tax revenue & 298.190 & 258.128 & 0.368 & 254.992 & 0.133 \\
\hline Public safety expenditures & 45.880 & 48.127 & 0.404 & 50.389 & 0.068 \\
\hline Law and order expenditures & 17.250 & 20.059 & 0.084 & 17.289 & 0.978 \\
\hline Public deficit & 2.004 & 18.399 & 0.189 & 14.122 & 0.054 \\
\hline
\end{tabular}




\section{Regression results on reported crime cases - police sta- tion closure}

Table C.1: Regression results, reported crime, broad crime categories

\begin{tabular}{|c|c|c|c|c|c|}
\hline & $\begin{array}{l}\text { Total } \\
\text { (1) }\end{array}$ & $\begin{array}{c}\text { Crime } \\
\text { against life } \\
\text { (2) }\end{array}$ & $\begin{array}{c}\text { Sex crime } \\
\text { (3) }\end{array}$ & $\begin{array}{c}\text { Robbery } \\
\text { (4) }\end{array}$ & $\begin{array}{l}\text { Theft } \\
\text { (5) }\end{array}$ \\
\hline reform & $\begin{array}{l}-0.022 \\
(0.021)\end{array}$ & $\begin{array}{l}-0.020 \\
(0.025)\end{array}$ & $\begin{array}{l}-0.025 \\
(0.042)\end{array}$ & $\begin{array}{c}0.085 \\
(0.038)\end{array}$ & $\begin{array}{r}-0.033 \\
(0.025)\end{array}$ \\
\hline Average & 456.04 & .31 & 4.95 & 2.21 & 170.72 \\
\hline Observations & 3,622 & 3,622 & 3,622 & 3,622 & 3,622 \\
\hline Municipalities & 334 & 334 & 334 & 334 & 334 \\
\hline
\end{tabular}

Notes: The table reports difference-in-differences estimation results for (log) reported crime for broad crime categories. Crime against life summarizes homicide, manslaughter, involuntary manslaughter and termination of pregnancy. Sex crime summarizes sex crime including violence, sexual abuse and utilization of sexual tastes. Robbery summarizes bank/post robbery, patrol station, drug-related robbery and robbery in apartments. Theft includes cars, mopeds, bicycles as well as minor crimes/rare crime cases such as guns, non-cash means of payment, artwork. Standard errors are heteroscedasticity robust and clustered at the municipality level.

Table C.2: Regression results, reported theft crime

\begin{tabular}{|c|c|c|c|c|c|}
\hline & $\begin{array}{l}\text { Cars } \\
(1)\end{array}$ & $\begin{array}{l}\text { Mopeds } \\
\text { (2) }\end{array}$ & $\begin{array}{l}\text { Bicycles } \\
\text { (3) }\end{array}$ & $\begin{array}{l}\text { Burglary apartment } \\
\text { (4) }\end{array}$ & $\begin{array}{c}\text { Burglary basement } \\
\text { (5) }\end{array}$ \\
\hline reform & $\begin{array}{c}0.168 \\
(0.046)\end{array}$ & $\begin{array}{c}0.081 \\
(0.049)\end{array}$ & $\begin{array}{c}-0.131 \\
(0.041)\end{array}$ & $\begin{array}{c}0.117 \\
(0.051)\end{array}$ & $\begin{array}{c}0.074 \\
(0.036)\end{array}$ \\
\hline Average & 2.15 & 2.96 & 21.97 & 6.38 & 1.67 \\
\hline Observations & 3,622 & 3,622 & 3,622 & 3,622 & 3,622 \\
\hline Municipalities & 334 & 334 & 334 & 334 & 334 \\
\hline
\end{tabular}

Notes: The table reports difference-in-differences estimation results for (log) reported crime for detailed crime categories within theft. Standard errors are heteroscedasticity robust and clustered at the municipality level. 


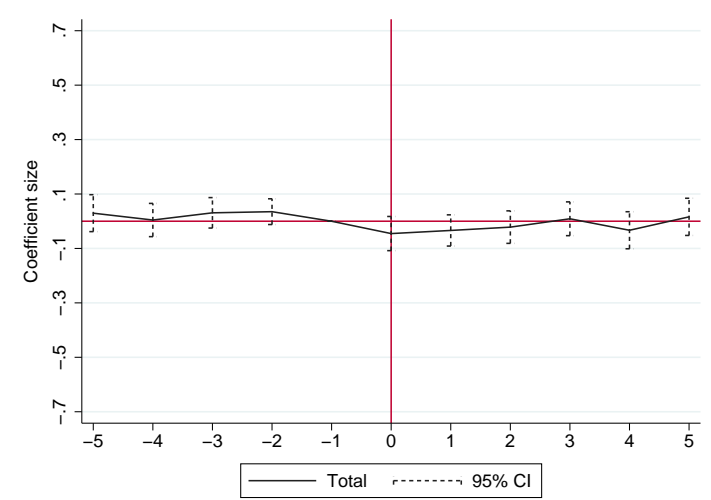

Total crime

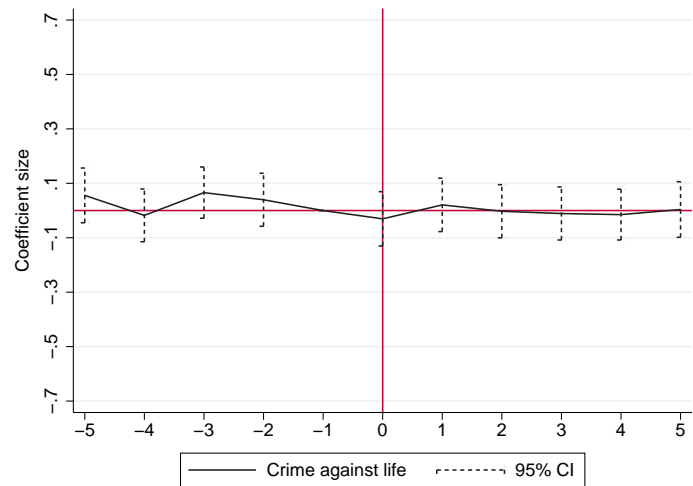

Crime against life

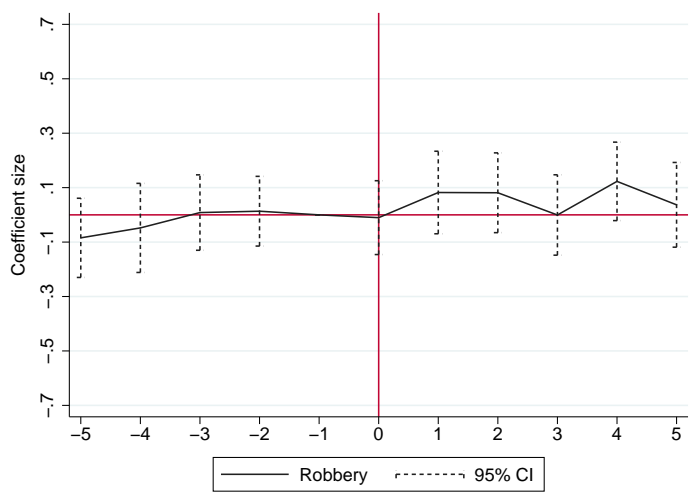

Robbery

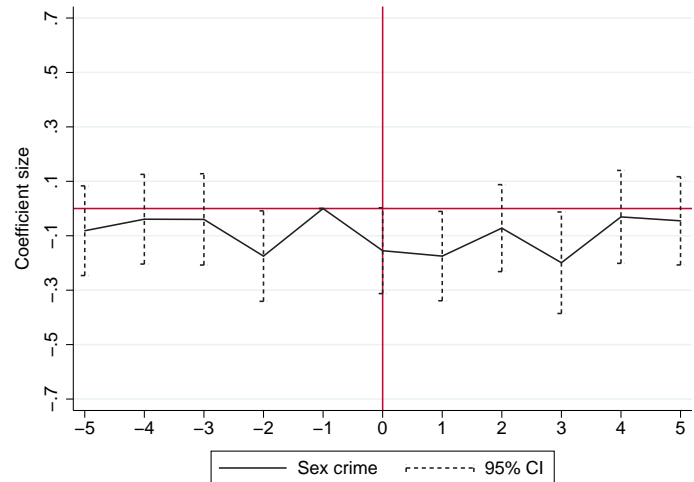

Sex crime

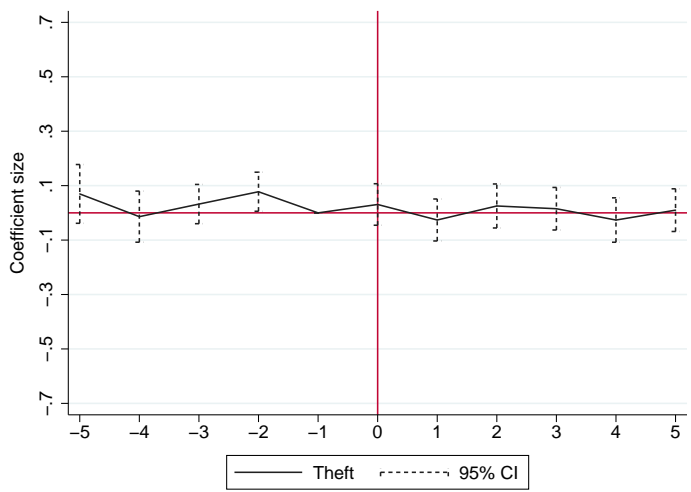

Theft

Notes: The figure reports event study estimation results on the $(\log )$ number of reported crime cases for total crime and four broad crime categories. The categories are homicide, sex crime, robbery and theft. Standard errors are heteroscedasticity robust and clustered at the municipality level. $95 \%$ confidence intervals are displayed by vertical bars.

Figure C.1: Treatment effect of police closure on broad crime categories 


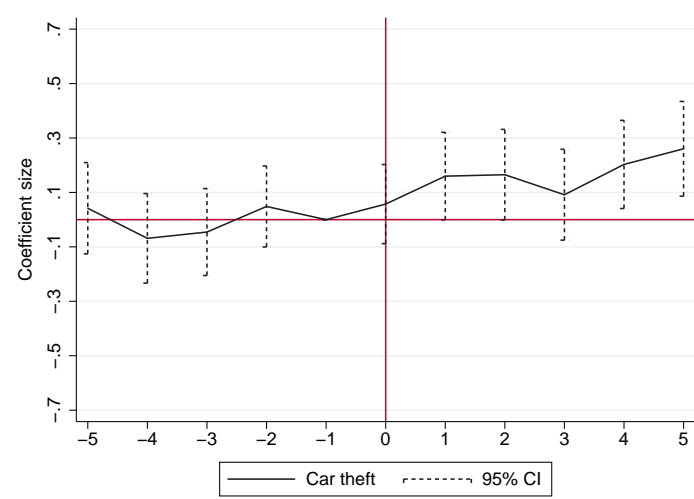

Car theft

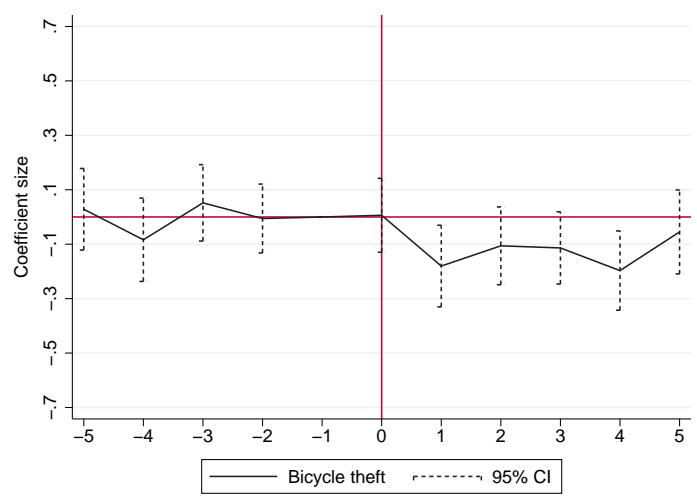

Bicycle theft

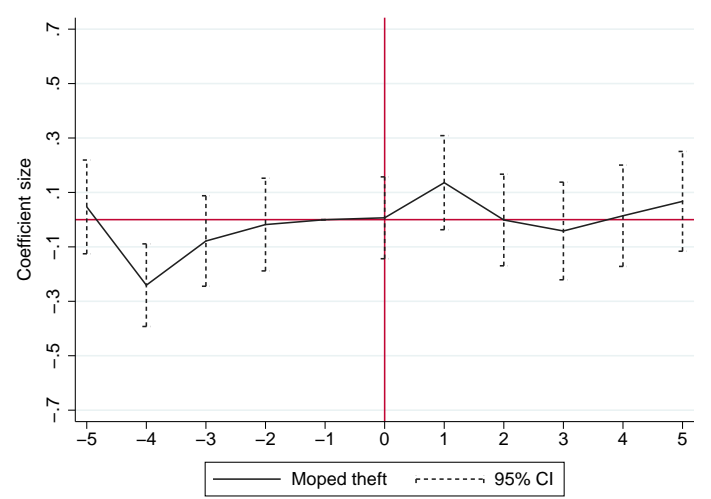

Moped theft

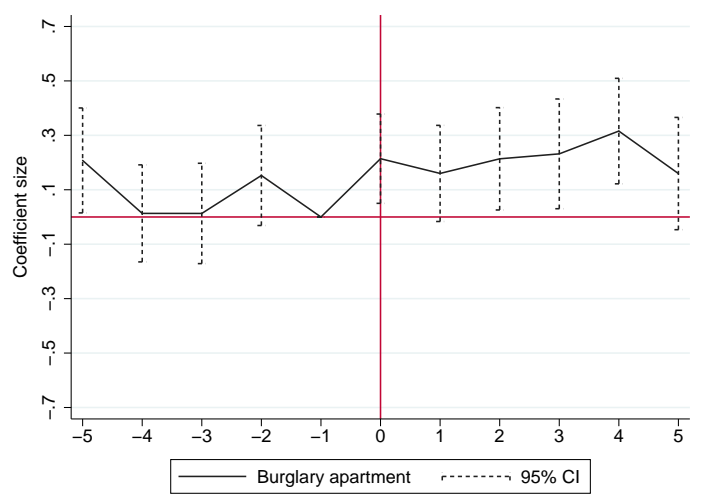

Burglary apartment

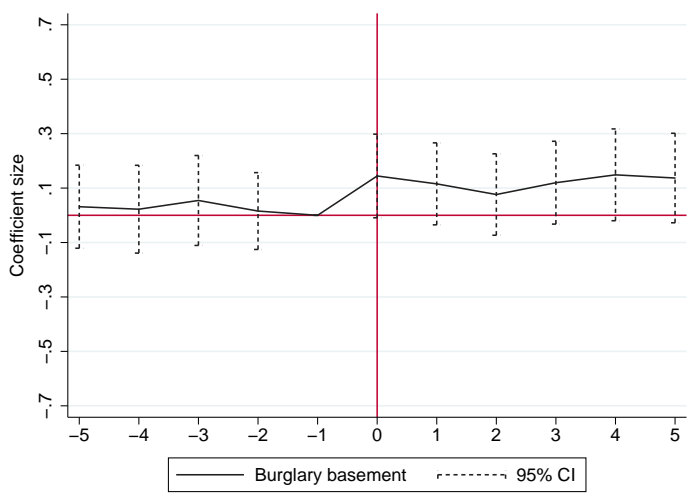

Burglary basement

Notes: The figure reports event study estimation results on the $(\log )$ number of reported crime cases among detailed crime categories within theft. Standard errors are heteroscedasticity robust and clustered at the municipality level. 95\% confidence intervals are displayed by vertical bars.

\section{Figure C.2: Treatment effect of police closure on theft crime categories}




\section{Robustness results}

Table D.1: Robustness of regression results, reported theft crime

\begin{tabular}{|c|c|c|c|c|c|}
\hline & $\begin{array}{c}\text { Cars } \\
(1)\end{array}$ & $\begin{array}{l}\text { Mopeds } \\
\text { (2) }\end{array}$ & $\begin{array}{l}\text { Bicycles } \\
\text { (3) }\end{array}$ & $\begin{array}{l}\text { Burglary apartment } \\
\text { (4) }\end{array}$ & $\begin{array}{c}\text { Burglary basement } \\
\text { (5) }\end{array}$ \\
\hline \multicolumn{6}{|c|}{ Panel A: all possible neighbors } \\
\hline \multirow[t]{2}{*}{ reform } & 0.168 & 0.066 & -0.127 & 0.119 & 0.068 \\
\hline & $(0.046)$ & $(0.049)$ & $(0.041)$ & $(0.052)$ & $(0.038)$ \\
\hline Average & 2.16 & 3.21 & 22.84 & 6.41 & 1.73 \\
\hline \multicolumn{6}{|c|}{ Panel B: closure events 2000-2010 } \\
\hline \multirow[t]{2}{*}{ reform } & 0.158 & 0.075 & -0.131 & 0.126 & 0.066 \\
\hline & $(0.044)$ & $(0.047)$ & $(0.040)$ & $(0.050)$ & $(0.035)$ \\
\hline Average & 2.09 & 2.86 & 21.33 & 6.31 & 1.62 \\
\hline \multicolumn{6}{|c|}{ Panel C: crime per 1,000 } \\
\hline \multirow[t]{2}{*}{ reform } & 0.037 & 0.064 & -0.139 & 0.074 & 0.016 \\
\hline & $(0.015)$ & $(0.022)$ & $(0.071)$ & $(0.040)$ & $(0.019)$ \\
\hline Average & .17 & .24 & 1.45 & .53 & .11 \\
\hline \multicolumn{6}{|c|}{ Panel D: district-specific time trends } \\
\hline \multirow[t]{2}{*}{ reform } & 0.130 & 0.110 & -0.114 & 0.124 & 0.060 \\
\hline & $(0.042)$ & $(0.048)$ & $(0.036)$ & $(0.048)$ & $(0.035)$ \\
\hline Average & 2.15 & 2.96 & 21.97 & 6.38 & 1.67 \\
\hline \multicolumn{6}{|c|}{ Panel E: placebo treatment 1999} \\
\hline \multirow[t]{2}{*}{ reform } & -0.027 & -0.007 & -0.027 & -0.066 & -0.005 \\
\hline & $(0.050)$ & $(0.056)$ & $(0.038)$ & $(0.054)$ & $(0.047)$ \\
\hline Average & 3.15 & 2.91 & 22.95 & 7.86 & 2.07 \\
\hline
\end{tabular}

Notes: The table reports difference-in-differences estimation results for (log) reported crime for detailed crime categories within theft using alternative empirical specifications. Standard errors are heteroscedasticity robust and clustered at the municipality level.

Table D.2: Monetary damage per case, reporting bias

\begin{tabular}{|c|c|c|c|c|c|}
\hline & $\begin{array}{l}\text { Car } \\
(1)\end{array}$ & $\begin{array}{l}\text { Moped } \\
\text { (2) }\end{array}$ & $\begin{array}{l}\text { Bicycle } \\
\text { (3) }\end{array}$ & $\begin{array}{l}\text { Burglary apartment } \\
\text { (4) }\end{array}$ & $\begin{array}{c}\text { Burglary basement } \\
\text { (5) }\end{array}$ \\
\hline reform & $\begin{array}{l}-1,476 \\
(1,404)\end{array}$ & $\begin{array}{c}400.4 \\
(260.6)\end{array}$ & $\begin{array}{c}36.73 \\
(29.04)\end{array}$ & $\begin{array}{l}-100.0 \\
(868.8)\end{array}$ & $\begin{array}{l}-40.54 \\
(137.8)\end{array}$ \\
\hline Average & 6612.261 & 1197.253 & 369.01 & 2446.758 & 448.72 \\
\hline Observations & 1,513 & 1,700 & 2,362 & 2,222 & 1,059 \\
\hline Municipalities & 334 & 334 & 334 & 334 & 334 \\
\hline
\end{tabular}




\section{E Mechanism results}

\section{E.1 Regression results on detection rates - police station closure}

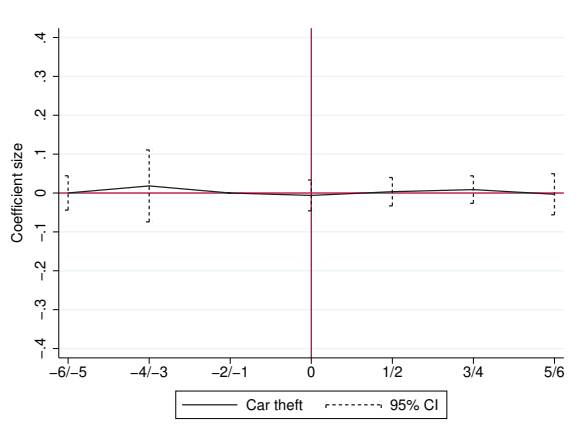

Car theft

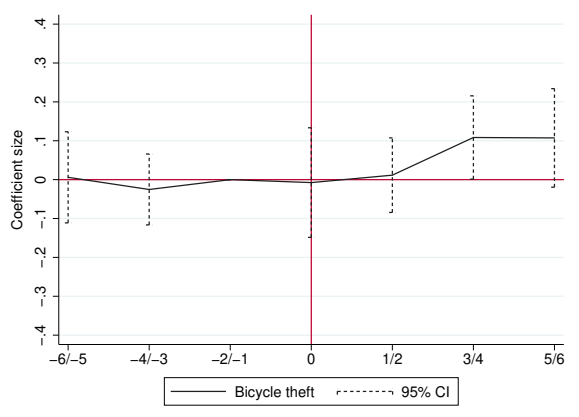

Bicycle theft

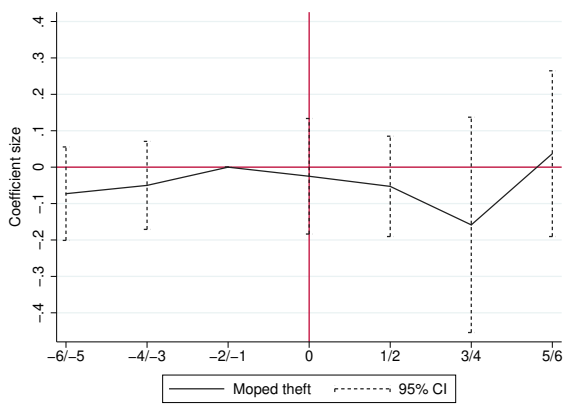

Moped theft

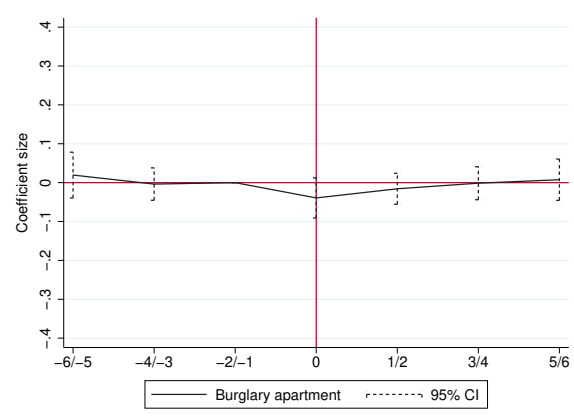

Burglary apartment

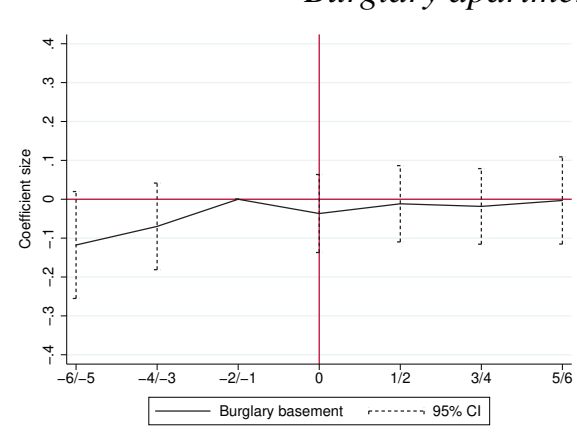

Burglary basement

Notes: The figure reports event study estimation results on detection rates among detailed crime categories within theft. Due to fact that estimation is conditional on positive reported crime case for municipality $i$ and time $t$, the regression model pools always two years. Standard errors are heteroscedasticity robust and clustered at the municipality level. $95 \%$ confidence intervals are displayed by vertical bars.

Figure E.1: Treatment effect of police closure on detection of theft crimes categories 


\section{E.2 Regression results on monetary damage - police station closure}
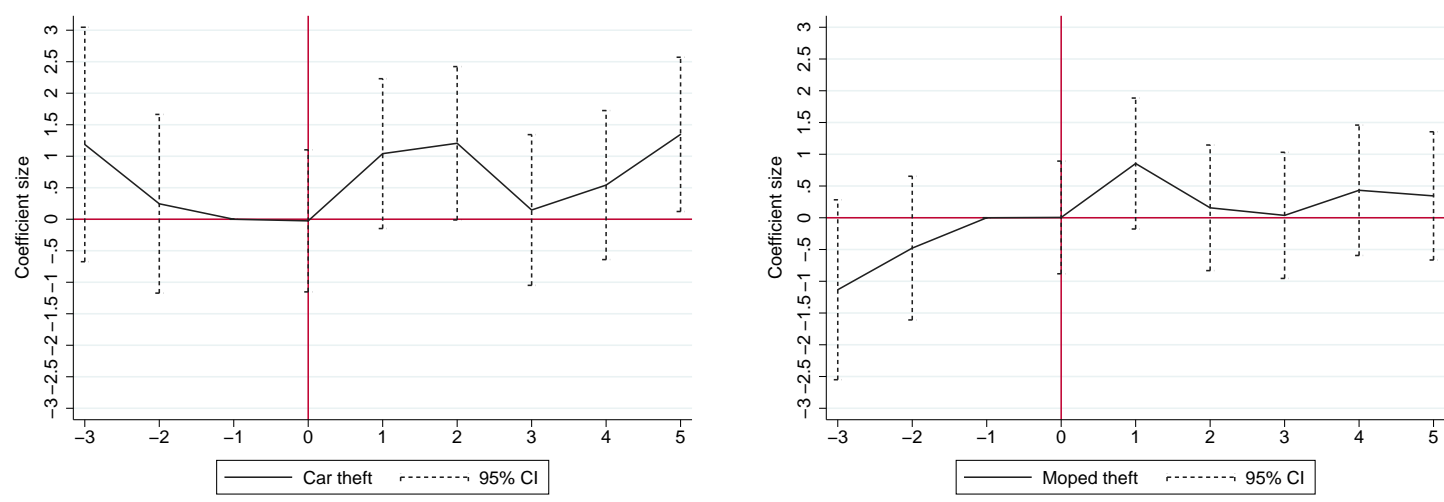

Car theft
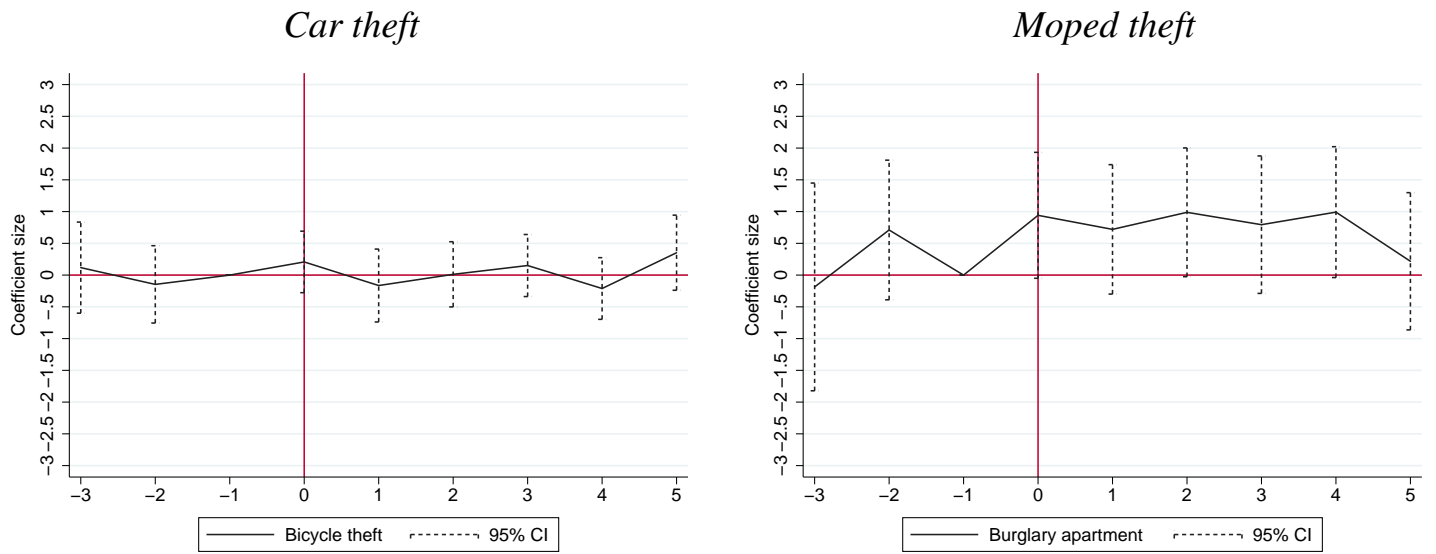

Bicycle theft

Burglary apartment

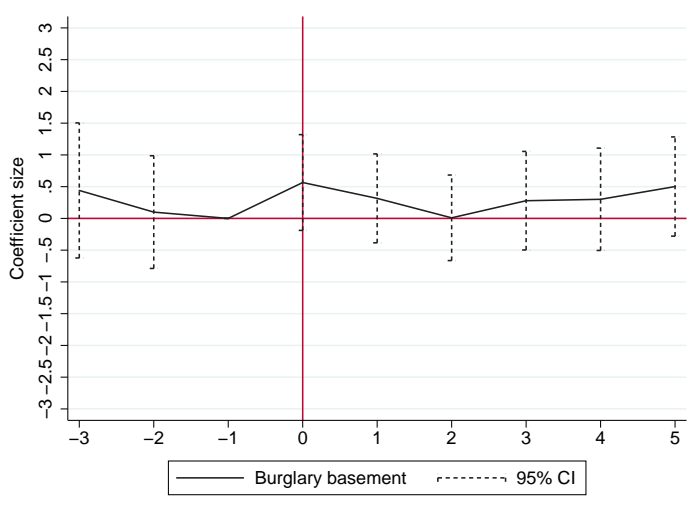

Burglary basement

Notes: The figure reports event study estimation results on (log) monetary damage among detailed crime categories within theft. Standard errors are heteroscedasticity robust and clustered at the municipality level. 95\% confidence intervals are displayed by vertical bars.

Figure E.2: Monetary damages of detailed theft categories 


\section{E.3 Reduction in police salience and physical presence}

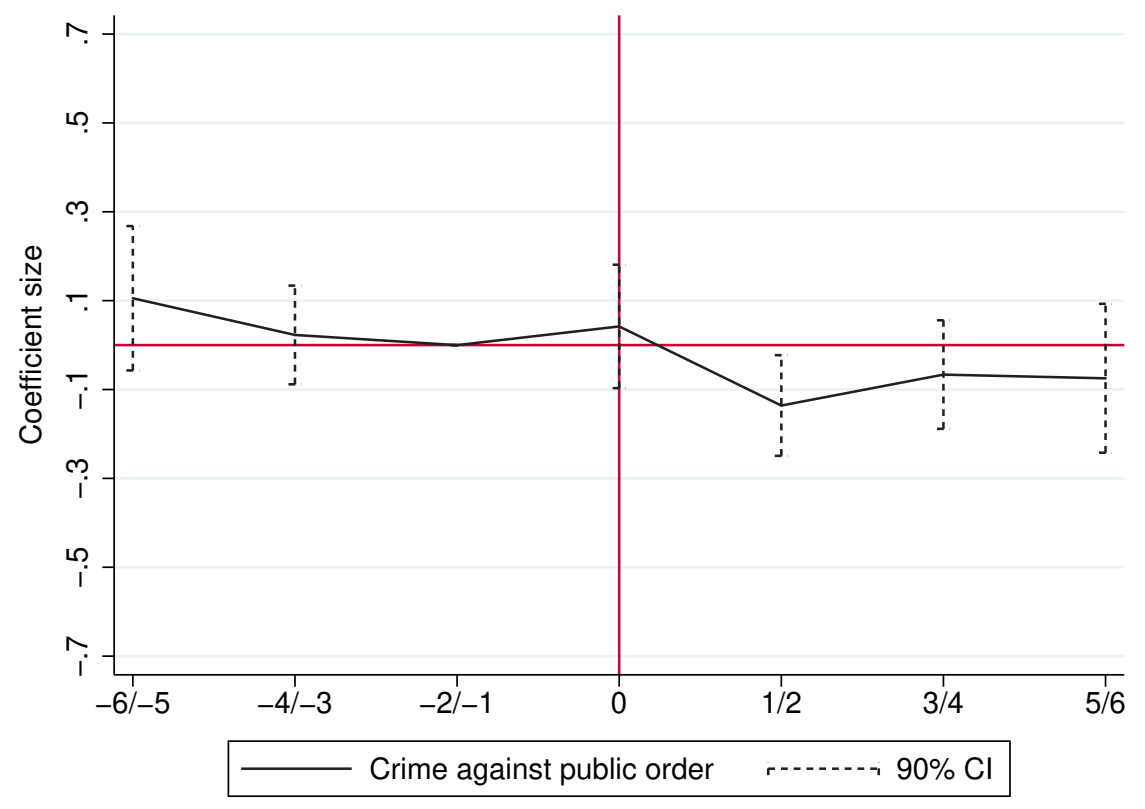

Notes: The figure reports event study estimation results on the $(\log )$ number of reported crime cases among crime against public order. The category includes crime against state authority, unlawful entry and mimicking criminal offenses. Due to relative rare cases, the regression model pools always two years. Standard errors are heteroscedasticity robust and clustered at the municipality level. $95 \%$ confidence intervals are displayed by vertical bars.

Figure E.3: Treatment effect of police closure on law enforcement and public order
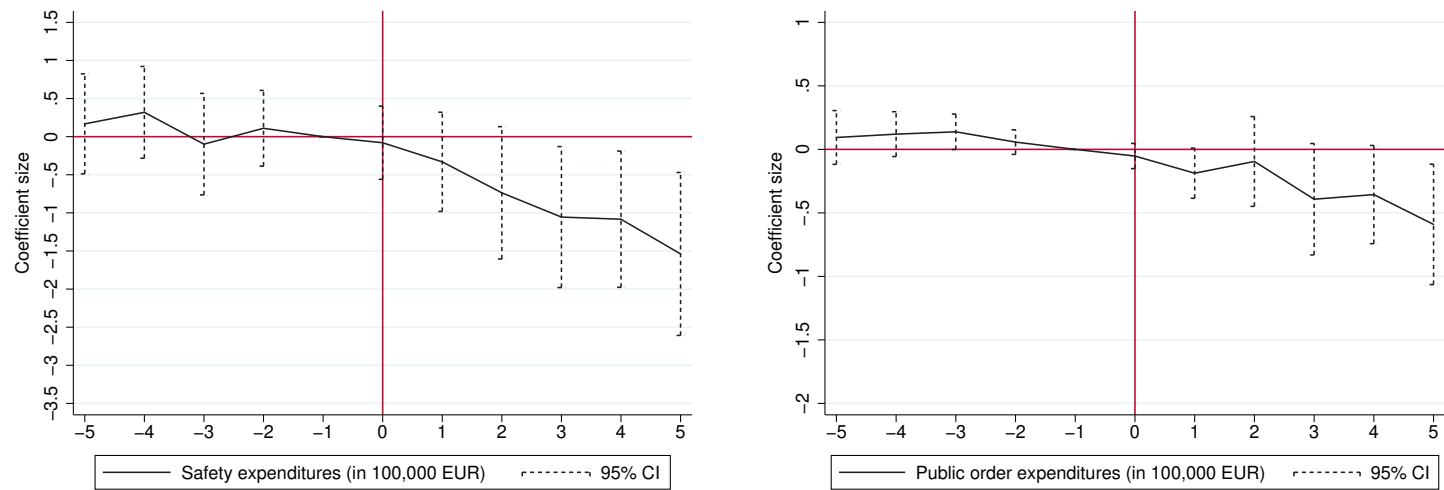

Notes: The figure reports event study estimation results on local policy responses measured as public safety as well as law and order spending. Standard errors are heteroscedasticity robust and clustered at the municipality level. $95 \%$ confidence intervals are displayed by vertical bars.

Figure E.4: Countervailing local policy responses using spending outcomes 


\section{E.4 Regression results - receiving municipalities}

\section{Matching approach}

Table E.1: Treated vs control municipalities - receiving regions

\begin{tabular}{|c|c|c|c|c|c|}
\hline & $\begin{array}{l}\text { Treated } \\
\text { (1) }\end{array}$ & $\begin{array}{l}\text { Control } \\
\text { (2) }\end{array}$ & $\begin{array}{l}p \text {-value } \\
\text { (3) }\end{array}$ & $\begin{array}{l}\text { All municipalities } \\
\text { (4) }\end{array}$ & $\begin{array}{l}p \text {-value } \\
\text { (5) }\end{array}$ \\
\hline \multicolumn{6}{|c|}{ Panel A: 1 year before treatment $\tau=-1$} \\
\hline \multicolumn{6}{|c|}{ Demographics } \\
\hline Population share $<15$ & 0.165 & 0.166 & 0.755 & 0.170 & 0.011 \\
\hline Population share $>65$ & 0.175 & 0.173 & 0.404 & 0.173 & 0.405 \\
\hline Unskilled & 0.209 & 0.184 & 0.000 & 0.191 & 0.019 \\
\hline Skilled & 0.687 & 0.717 & 0.000 & 0.719 & 0.001 \\
\hline High-skilled & 0.103 & 0.099 & 0.557 & 0.089 & 0.037 \\
\hline Female & 0.480 & 0.470 & 0.165 & 0.471 & 0.335 \\
\hline Foreigners & 0.095 & 0.093 & 0.867 & 0.068 & 0.000 \\
\hline \multicolumn{6}{|l|}{ Labor market indicators } \\
\hline Real daily wage & 120.465 & 120.883 & 0.859 & 118.306 & 0.369 \\
\hline Unemployment rate & 0.025 & 0.025 & 0.754 & 0.016 & 0.000 \\
\hline ALMP & 0.009 & 0.008 & 0.216 & 0.007 & 0.013 \\
\hline \multicolumn{6}{|l|}{ Occupational structure } \\
\hline$\overline{\text { Agriculture }}$ & 0.014 & 0.011 & 0.067 & 0.014 & 0.920 \\
\hline Production & 0.302 & 0.304 & 0.764 & 0.316 & 0.174 \\
\hline Salary & 0.138 & 0.139 & 0.819 & 0.138 & 0.972 \\
\hline Sale & 0.070 & 0.066 & 0.299 & 0.065 & 0.315 \\
\hline Clerical & 0.241 & 0.239 & 0.848 & 0.234 & 0.487 \\
\hline Service & 0.236 & 0.240 & 0.540 & 0.232 & 0.629 \\
\hline \multicolumn{6}{|l|}{ Revenuelexpenditure } \\
\hline$\overline{\text { Income tax revenue }}$ & 320.259 & 325.229 & 0.460 & 319.099 & 0.828 \\
\hline Commercial tax revenue & 292.062 & 267.899 & 0.362 & 309.475 & 0.658 \\
\hline Public safety expenditures & 56.781 & 56.833 & 0.989 & 52.235 & 0.147 \\
\hline Law and order expenditures & 25.897 & 27.153 & 0.582 & 17.243 & 0.000 \\
\hline Public deficit & 7.611 & 9.546 & 0.884 & -1.198 & 0.171 \\
\hline \multicolumn{6}{|c|}{ Panel B: 4 years before treatment $\tau=-4$} \\
\hline Population share $>65$ & 0.159 & 0.158 & 0.495 & 0.158 & 0.665 \\
\hline Unskilled & 0.216 & 0.204 & 0.105 & 0.204 & 0.105 \\
\hline Skilled & 0.689 & 0.705 & 0.039 & 0.714 & 0.011 \\
\hline High-skilled & 0.095 & 0.091 & 0.504 & 0.083 & 0.075 \\
\hline Female & 0.477 & 0.466 & 0.170 & 0.468 & 0.353 \\
\hline Foreigners & 0.096 & 0.094 & 0.735 & 0.069 & 0.000 \\
\hline \multicolumn{6}{|l|}{ Labor market indicators } \\
\hline Real daily wage & 119.001 & 121.964 & 0.213 & 119.131 & 0.956 \\
\hline Unemployment rate & 0.023 & 0.023 & 0.763 & 0.022 & 0.001 \\
\hline ALMP & 0.007 & 0.005 & 0.048 & 0.005 & 0.007 \\
\hline \multicolumn{6}{|l|}{ Occupational structure } \\
\hline$\overline{\text { Agriculture }}$ & 0.013 & 0.012 & 0.681 & 0.014 & 0.455 \\
\hline Production & 0.309 & 0.318 & 0.412 & 0.318 & 0.412 \\
\hline Salary & 0.136 & 0.130 & 0.342 & 0.132 & 0.568 \\
\hline Sale & 0.074 & 0.064 & 0.011 & 0.062 & 0.028 \\
\hline Clerical & 0.239 & 0.239 & 0.950 & 0.234 & 0.570 \\
\hline Service & 0.229 & 0.238 & 0.239 & 0.228 & 0.861 \\
\hline \multicolumn{6}{|l|}{ Revenuelexpenditure } \\
\hline$\overline{\text { Income tax revenue }}$ & 350.028 & 357.716 & 0.254 & 329.385 & 0.000 \\
\hline Commercial tax revenue & 282.703 & 254.688 & 0.283 & 254.719 & 0.338 \\
\hline Public safety expenditures & 61.387 & 55.484 & 0.325 & 50.099 & 0.001 \\
\hline Law and order expenditures & 29.624 & 26.697 & 0.556 & 16.717 & 0.000 \\
\hline Public deficit & 23.579 & 5.237 & 0.162 & 11.341 & 0.048 \\
\hline
\end{tabular}




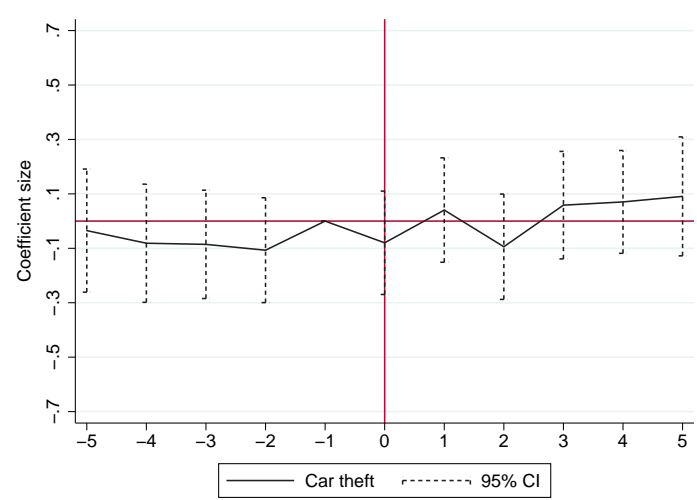

Car theft

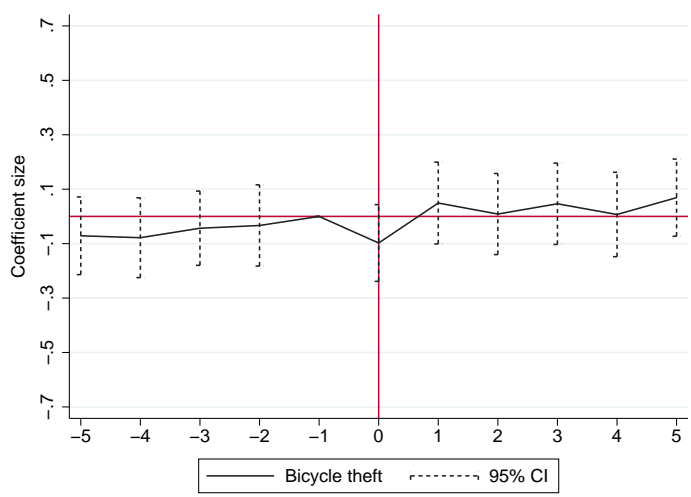

Bicycle theft

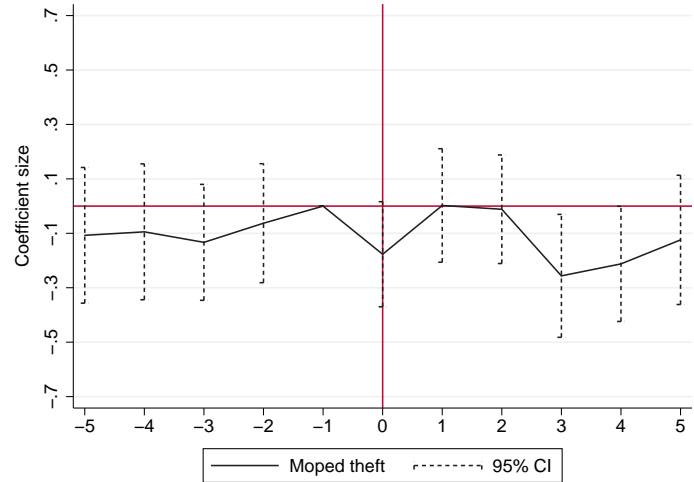

Moped theft

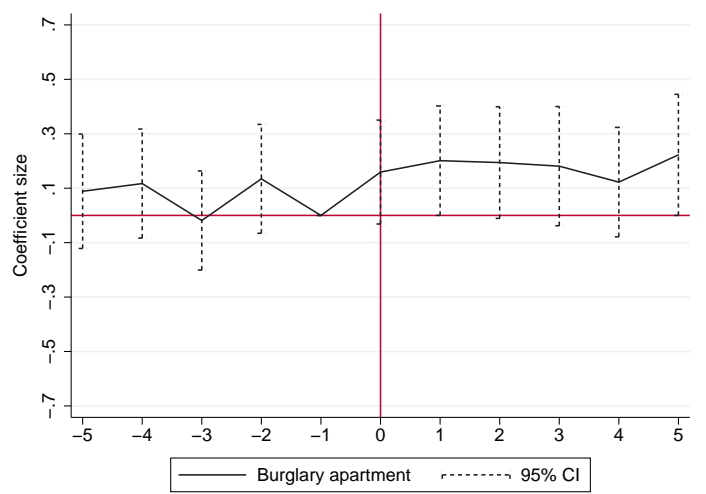

Burglary apartment

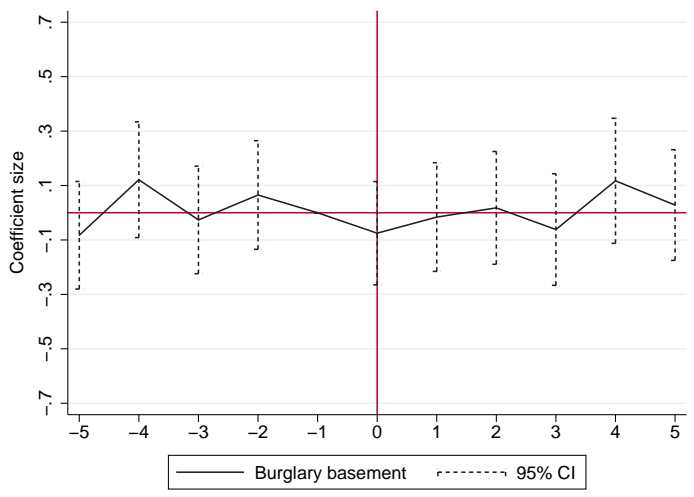

Burglary basement

Notes: The figure reports event study estimation results on the $(\log )$ number of reported crime cases among detailed crime categories within theft. Standard errors are heteroscedasticity robust and clustered at the municipality level. 95\% confidence intervals are displayed by vertical bars.

Figure E.5: Treatment effect of received police staff on theft 


\section{Detection rates}
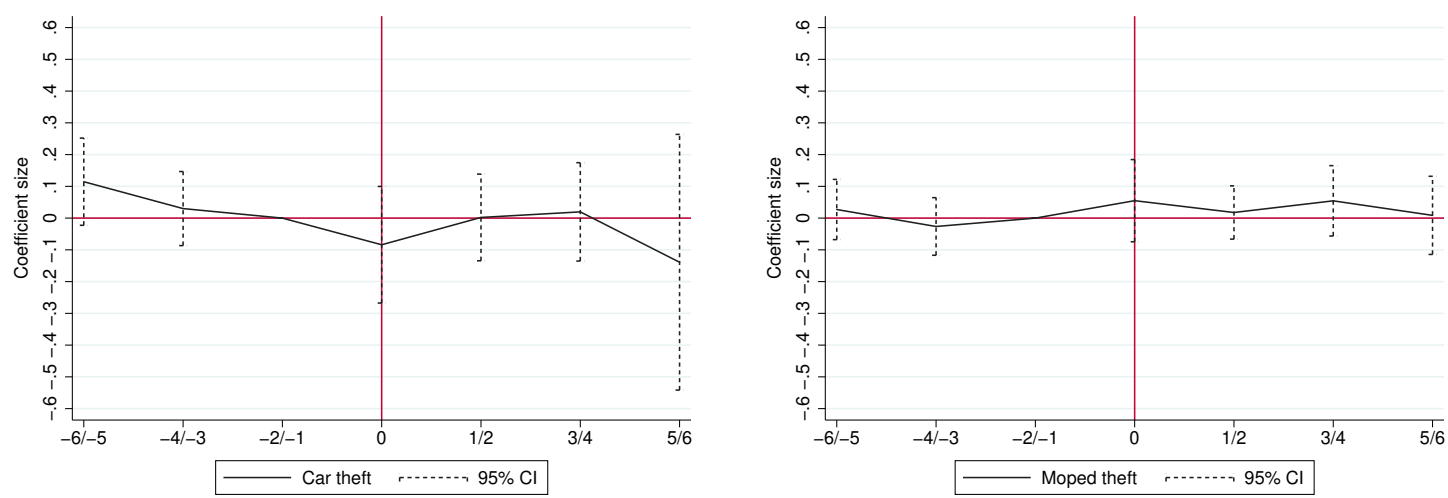

Car theft
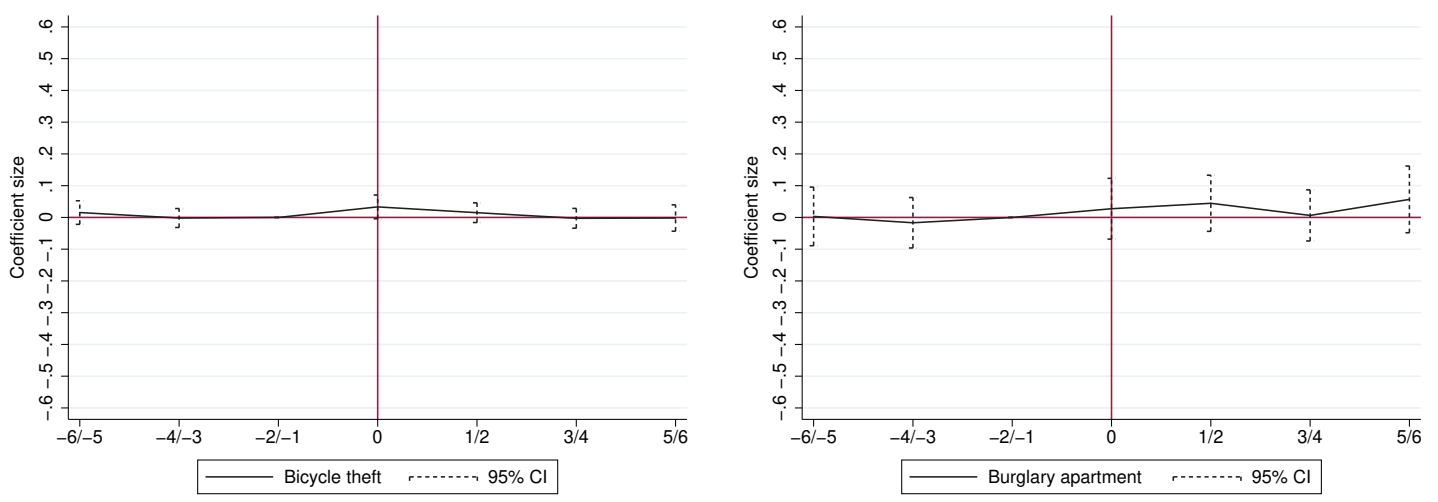

Bicycle theft

Burglary apartment

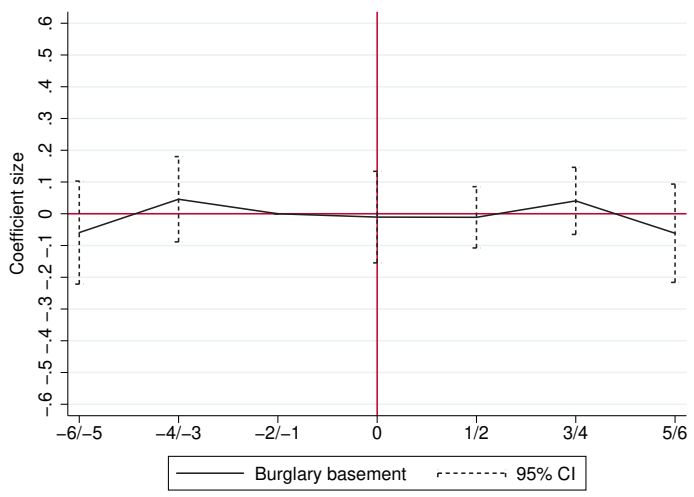

Burglary basement

Notes: The figure reports event study estimation results on detection rates among detailed crime categories within theft. Due to fact that estimation is conditional on positive reported crime case for municipality $i$ and time $t$, the regression model pools always two years. Standard errors are heteroscedasticity robust and clustered at the municipality level. $95 \%$ confidence intervals are displayed by vertical bars.

Figure E.6: Treatment effect of received police staff on detection rates of theft crime 


\section{E.5 Regression results by distance - reported crime}

Table E.2: Regression results by distance, reported theft crime

\begin{tabular}{|c|c|c|c|c|c|}
\hline & $\begin{array}{c}\text { Cars } \\
(1)\end{array}$ & $\begin{array}{l}\text { Mopeds } \\
\text { (2) }\end{array}$ & $\begin{array}{c}\text { Bicycles } \\
\text { (3) }\end{array}$ & $\begin{array}{l}\text { Burglary apartment } \\
\text { (4) }\end{array}$ & $\begin{array}{c}\text { Burglary basement } \\
\text { (5) }\end{array}$ \\
\hline \multicolumn{6}{|c|}{ Panel A: distance to next station $\leq 6 \mathrm{~km}$} \\
\hline reform & $\begin{array}{l}-0.061 \\
(0.085)\end{array}$ & $\begin{array}{c}0.069 \\
(0.097)\end{array}$ & $\begin{array}{l}-0.015 \\
(0.089)\end{array}$ & $\begin{array}{c}0.059 \\
(0.090)\end{array}$ & $\begin{array}{c}0.017 \\
(0.083)\end{array}$ \\
\hline Average & 1.65 & 2.44 & 15.28 & 5.73 & 1.38 \\
\hline Observations & 1,117 & 1,117 & 1,117 & 1,117 & 1,117 \\
\hline Municipalities & 103 & 103 & 103 & 103 & 103 \\
\hline \multicolumn{6}{|c|}{ Panel B: distance to next station $>6 \mathrm{~km}$} \\
\hline reform & 0.168 & 0.078 & $\begin{array}{l}-0.204 \\
(0.057)\end{array}$ & $\begin{array}{c}0.156 \\
(0.070)\end{array}$ & $\begin{array}{c}0.107 \\
(0.045)\end{array}$ \\
\hline Average & 2.38 & $\begin{array}{l}(0.004) \\
3.21\end{array}$ & 25.05 & $\begin{array}{c}(0.070) \\
6.7\end{array}$ & 1.81 \\
\hline Observations & 2,494 & 2,494 & 2,494 & 2,494 & 2,494 \\
\hline Municipalities & 230 & 230 & 230 & 230 & 230 \\
\hline
\end{tabular}

Notes: The table reports difference-in-differences estimation results for (log) reported crime for detailed crime categories within theft. Panel A shows the results for $(\log )$ reported crime among treated municipalities with a distance to the next police station below 6.0 $\mathrm{km}$. Panel B shows the results for ( $\mathrm{log}$ ) reported crime among treated municipalities with a distance to the next police station above $6.0 \mathrm{~km}$. Standard errors are heteroscedasticity robust and clustered at the municipality level. 


\section{E.6 Number of suspects - municipalities from the sample of police station closures}

Table E.3: Total number of suspects and total number of suspects per crime case, theft

\begin{tabular}{lcc}
\hline \hline & $\begin{array}{c}\text { Total number } \\
\text { of suspects } \\
(1)\end{array}$ & $\begin{array}{c}\text { Total number } \\
\text { of suspects per case } \\
(2)\end{array}$ \\
\hline reform & 0.010 & -0.009 \\
& $(0.038)$ & $(0.037)$ \\
Average & 3.148 & 0.288 \\
Observations & 3,622 & 3,613 \\
Municipalities & 334 & 334 \\
\hline Notes: The table reports difference-in-differences regression results of the total (log) number of suspects (column 1) and the total \\
number of suspects per reported crime case (column 2) on the reform indicator.
\end{tabular}

Table E.4: Total number of suspects by detailed theft crime type

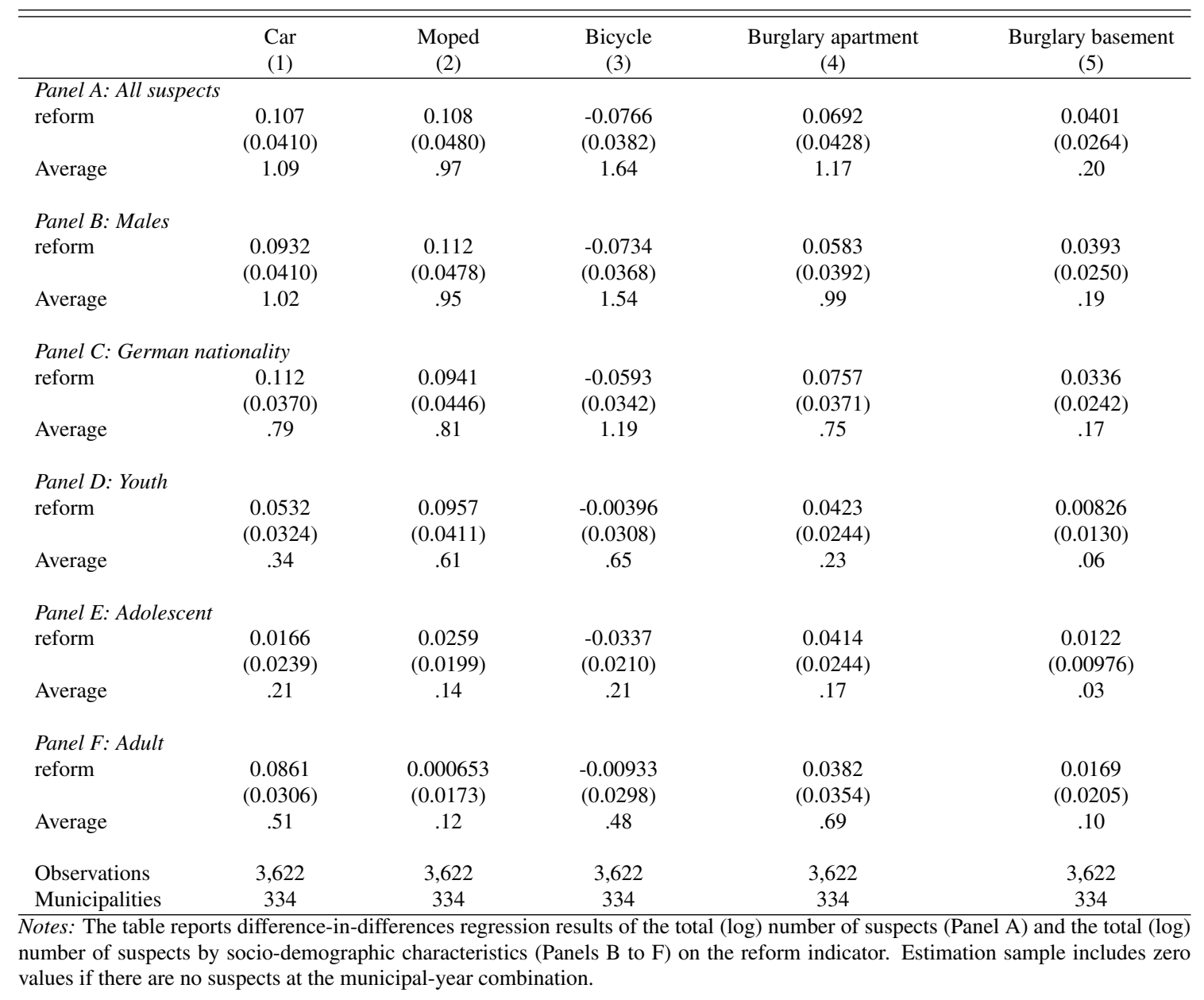




\section{Appendix for online publication}

\section{A Reported crime from police station closure}

Table OA-A.1: Regression results, detailed body-related crime

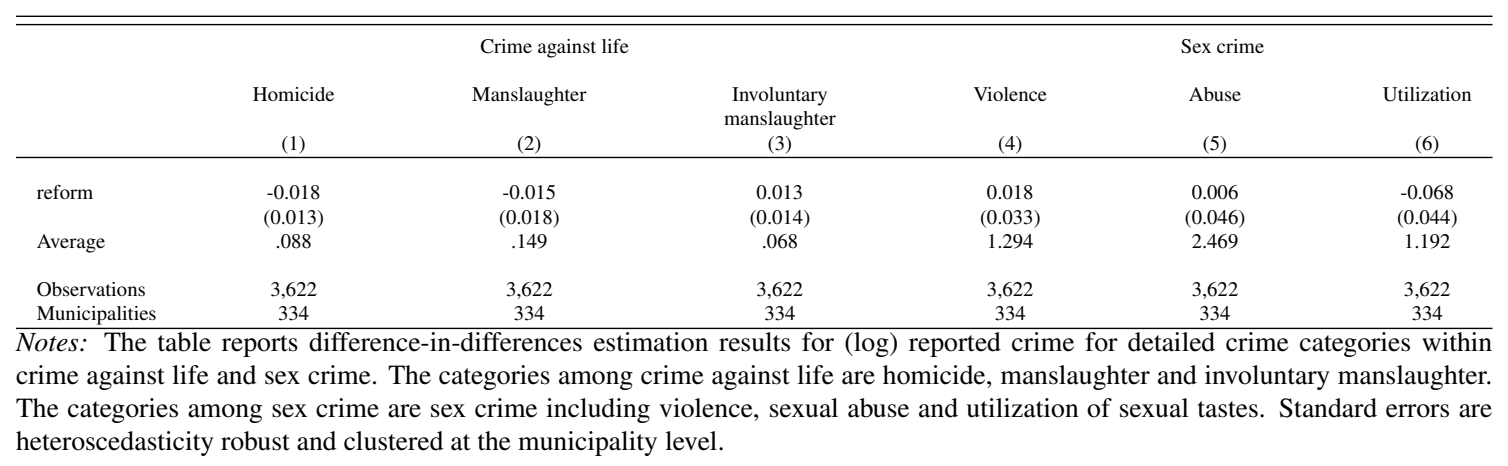

Table OA-A.2: Regression results, detailed robbery

\begin{tabular}{lcccc}
\hline \hline & $\begin{array}{c}\text { Banks/ } \\
\text { Post } \\
(1)\end{array}$ & $\begin{array}{c}\text { Patrol } \\
\text { station } \\
(2)\end{array}$ & $\begin{array}{c}\text { Drug-related } \\
\text { robbery } \\
(3)\end{array}$ & $\begin{array}{c}\text { Robbery in } \\
\text { apartments } \\
(4)\end{array}$ \\
\hline reform & 0.012 & -0.007 & 0.005 & $(0.008)$ \\
Average & $(0.015)$ & $(0.018)$ & .027 & 0.025 \\
Observations & .082 & .138 & $3,021)$ & .171 \\
Municipalities & 3,622 & 3,622 & 3,622 & 3,622 \\
\hline
\end{tabular}

Notes: The table reports difference-in-differences estimation results for (log) reported crime for detailed crime categories within robbery. The categories among robbery are robbery from banks/post stations, patrol station, drug-related robbery and robbery in apartments. Standard errors are heteroscedasticity robust and clustered at the municipality level. 

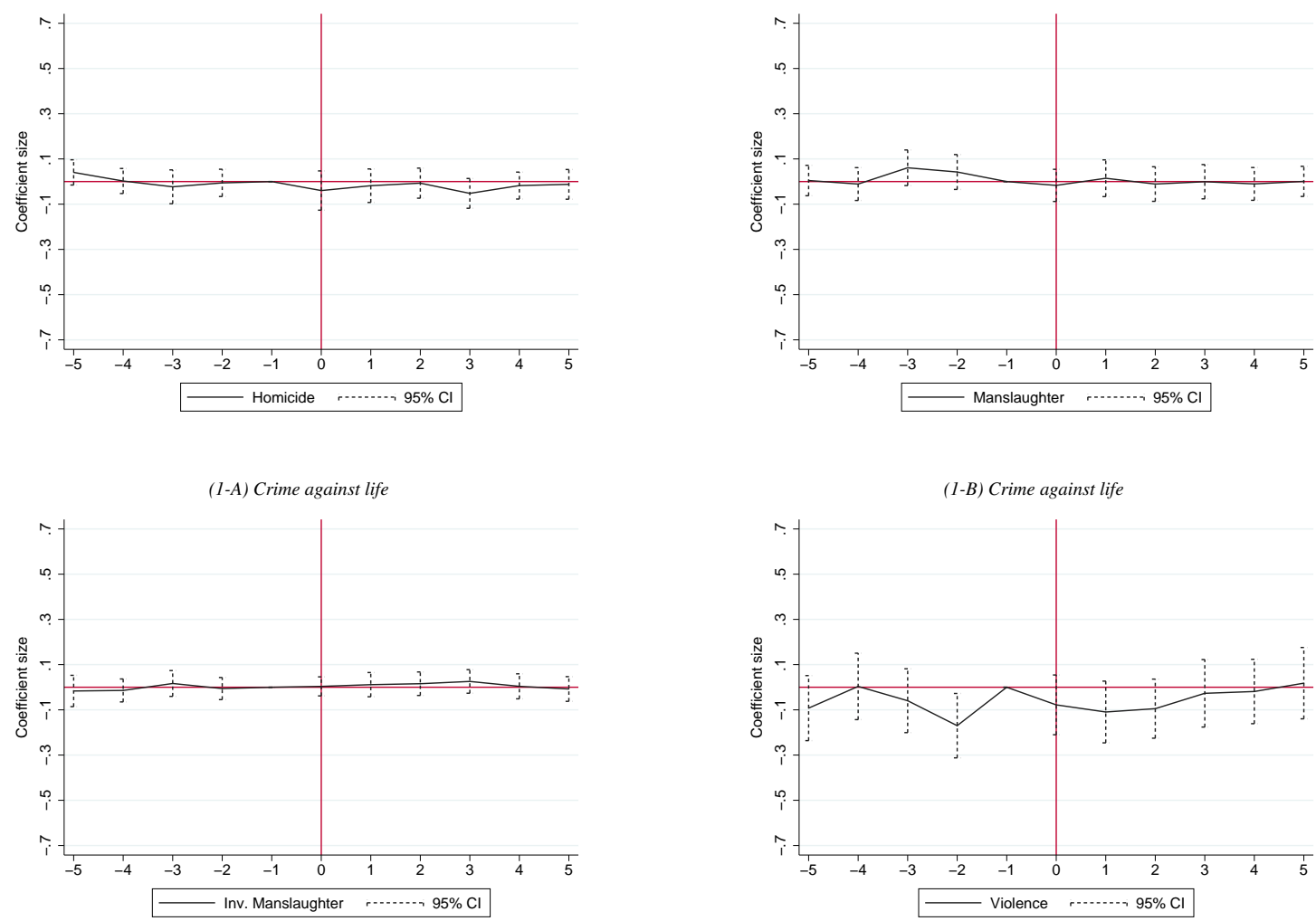

(1-C) Crime against life

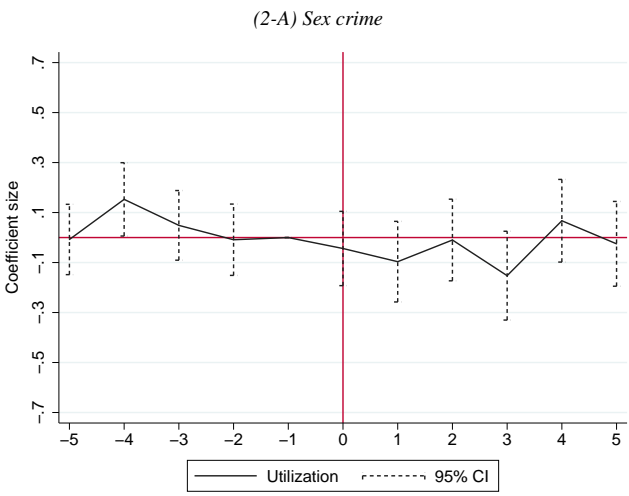

(2-B) Sex crime

(2-C) Sex crime

Notes: The figure reports event study estimation results on the (log) number of reported crime cases among detailed crime categories within crime against life and sex crime. The categories among crime against life are homicide, manslaughter and involuntary manslaughter. The categories among sex crime are sex crime including violence, sexual abuse and utilization of sexual tastes. Standard errors are heteroscedasticity robust and clustered at the municipality level. $95 \%$ confidence intervals are displayed by vertical bars.

Figure OA-A.1: Treatment effect of police closure on body-related crime 


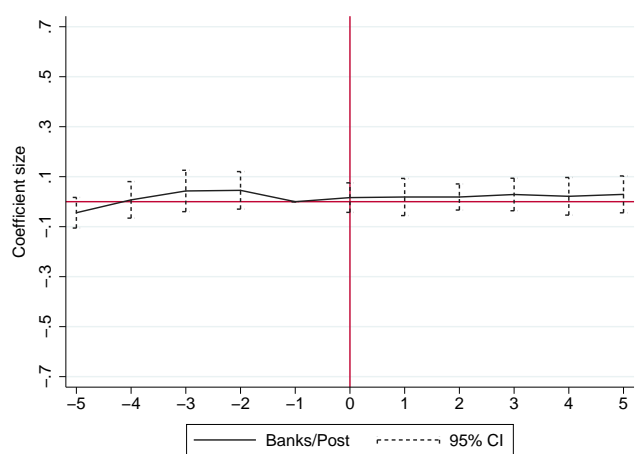

(1-A) Robbery

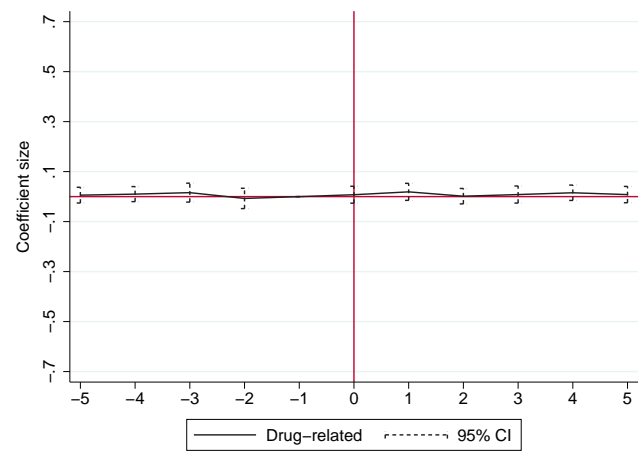

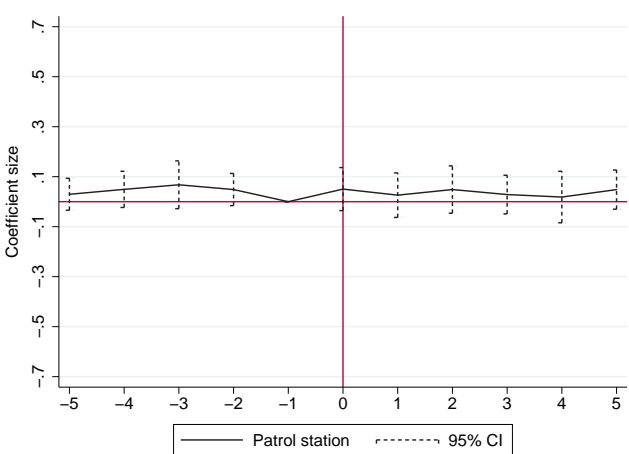

(1-B) Robbery

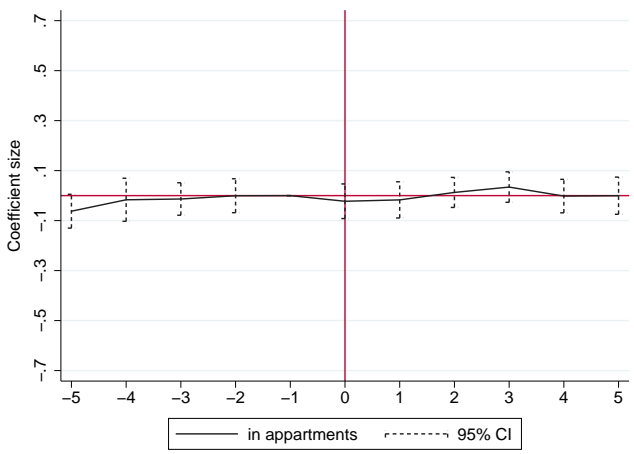

(1-D) Robbery

Notes: The figure reports event study estimation results on the (log) number of reported crime cases among detailed crime categories within robbery. The categories among robbery are robbery from banks/post stations, patrol station, drug-related robbery and robbery in apartments. Standard errors are heteroscedasticity robust and clustered at the municipality level. 95\% confidence intervals are displayed by vertical bars.

Figure OA-A.2: Treatment effect of police closure on robbery 


\section{B Detection rates from police station closure}

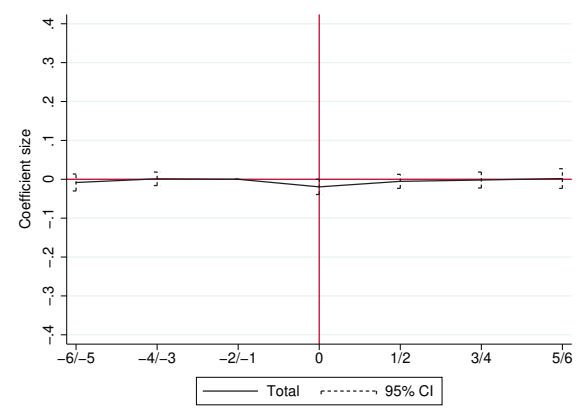

Total crime

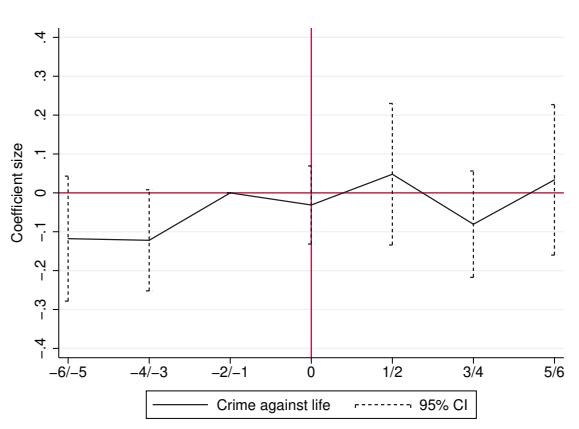

Crime against life

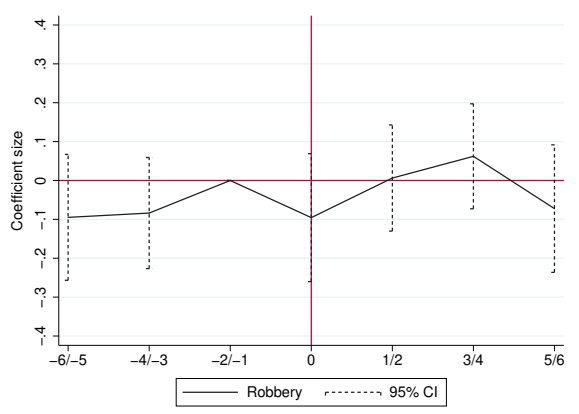

Robbery

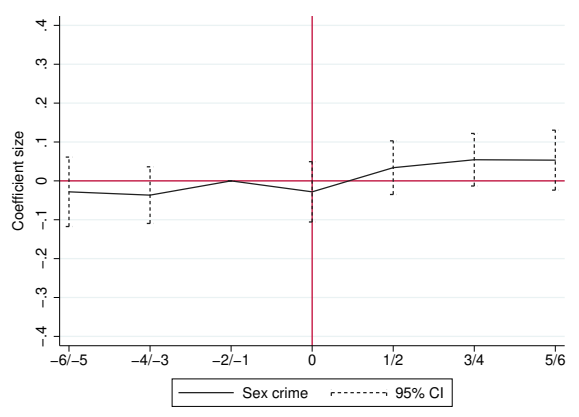

Sex crime

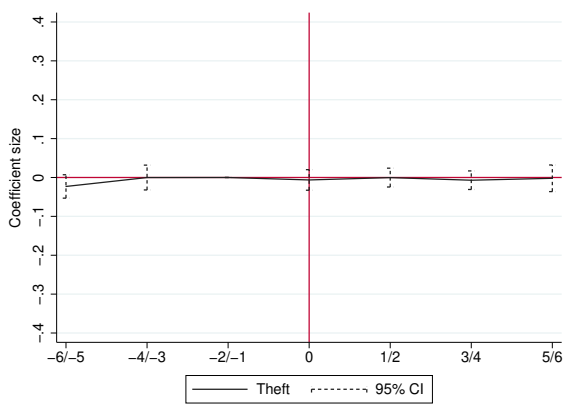

Theft

Notes: The figure reports event study estimation results on detection rates for total crime and 4 broad crime categories. The categories are homicide, sex crime, robbery and theft. Due to fact that estimation is conditional on positive reported crime case for municipality $i$ and time $t$, the regression model pools two years. Standard errors are heteroscedasticity robust and clustered at the municipality level. $95 \%$ confidence intervals are displayed by vertical bars.

Figure OA-B.1: Treatment effect of police closure on detection rates of broad crime categories 


\section{Changing labor market conditions}
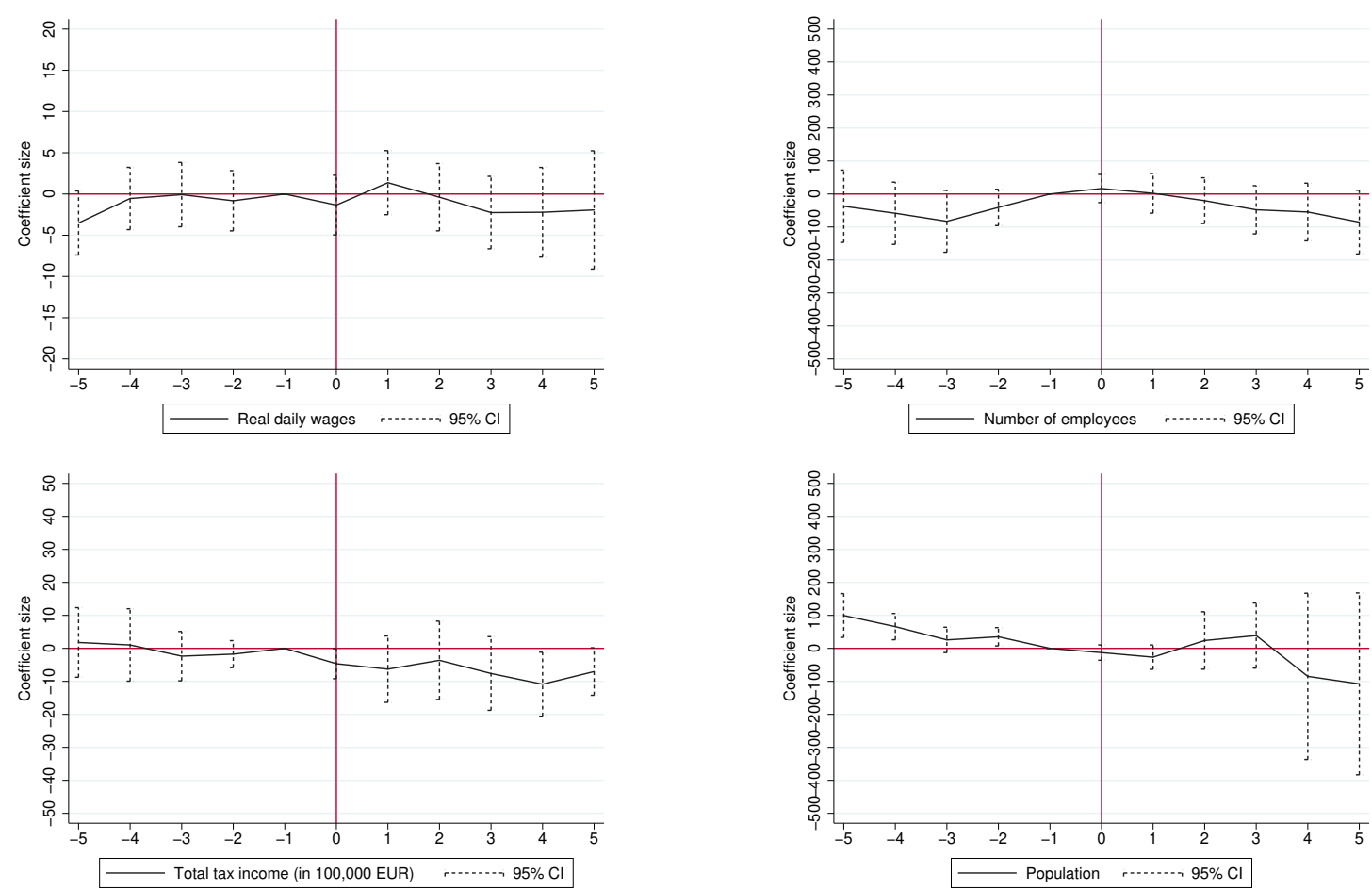

Notes: The figure reports event study estimation results on selected outcome variables that provide evidence on potential identification threats. The outcome variables are real daily wage, total number of employees, total tax income and population size. Standard errors are heteroscedasticity robust and clustered at the municipality level. 95\% confidence intervals are displayed by vertical bars.

Figure OA-C.1: Testing identification threats from worsening labor market conditions 


\section{Results - municipalities from the sample with received police staff}

\section{D.1 Reported crime cases}

Table OA-D.1: Regression results of received police staff, broad crime categories

\begin{tabular}{|c|c|c|c|c|c|}
\hline & $\begin{array}{l}\text { Total } \\
\text { (1) }\end{array}$ & $\begin{array}{c}\text { Crime } \\
\text { against life } \\
(2)\end{array}$ & $\begin{array}{c}\text { Sex crime } \\
\text { (3) }\end{array}$ & $\begin{array}{c}\text { Robbery } \\
\text { (4) }\end{array}$ & $\begin{array}{l}\text { Theft } \\
\text { (5) }\end{array}$ \\
\hline reform & $\begin{array}{c}-0.002 \\
(0.025)\end{array}$ & $\begin{array}{c}0.023 \\
(0.035)\end{array}$ & $\begin{array}{c}0.030 \\
(0.045)\end{array}$ & $\begin{array}{c}0.097 \\
(0.049)\end{array}$ & $\begin{array}{c}0.028 \\
(0.024)\end{array}$ \\
\hline Average & 661.83 & .45 & 6.67 & 74.01 & 258.55 \\
\hline Observations & 2,642 & 2,642 & 2,642 & 2,642 & 2,642 \\
\hline Municipalities & 244 & 244 & 244 & 244 & 244 \\
\hline Average & $625,405.30$ & 390.49 & $6,006.72$ & 4.19 & $26,2761.83$ \\
\hline
\end{tabular}

Notes: The table reports difference-in-differences estimation results for broad crime categories. Crime against life summarizes homicide, manslaughter, involuntary manslaughter and termination of pregnancy. Sex crime summarizes sex crime including violence, sexual abuse as well as utilization of sexual tastes. Robbery summarizes bank/post robbery, patrol station, drug-related robbery and robbery in apartments. Theft includes cars, mopeds, bicycles as well as minor crimes/rare crime cases such as guns, non-cash means of payment, artwork. The dependent variable corresponds to (log) reported crime. Standard errors are heteroscedasticity robust and clustered at the municipality level.

Table OA-D.2: Regression results of received police staff, detailed body-related crime

\begin{tabular}{|c|c|c|c|c|c|c|}
\hline & \multicolumn{3}{|c|}{ Crime against life } & \multicolumn{3}{|c|}{ Sex crime } \\
\hline & $\begin{array}{c}\text { Homicide } \\
\text { (1) }\end{array}$ & $\begin{array}{c}\text { Manslaughter } \\
\text { (2) }\end{array}$ & $\begin{array}{c}\text { Involuntary } \\
\text { manslaughter } \\
(3)\end{array}$ & $\begin{array}{c}\text { Violence } \\
\text { (4) } \\
\end{array}$ & $\begin{array}{c}\text { Abuse } \\
\text { (5) }\end{array}$ & $\begin{array}{c}\text { Utilization } \\
(6)\end{array}$ \\
\hline reform & $\begin{array}{c}0.005 \\
(0.025)\end{array}$ & $\begin{array}{c}0.030 \\
(0.028)\end{array}$ & $\begin{array}{c}-0.006 \\
(0.017)\end{array}$ & $\begin{array}{c}0.055 \\
(0.047)\end{array}$ & $\begin{array}{c}0.027 \\
(0.050)\end{array}$ & $\begin{array}{c}0.031 \\
(0.052)\end{array}$ \\
\hline Observations & 2,642 & 2,642 & 2,642 & 2,642 & 2,642 & 2,642 \\
\hline Municipalities & 244 & 244 & 244 & 244 & 244 & 244 \\
\hline Average & .133 & .247 & .099 & 2.061 & 3.973 & 1.78 \\
\hline
\end{tabular}

Notes: The table reports difference-in-differences estimation results for detailed crime categories within crime against life and sex crime. The categories among crime against life are homicide, manslaughter and involuntary manslaughter. The categories among sex crime are sex crime including violence, sexual abuse and utilization of sexual tastes. The dependent variable corresponds to (log) reported crime. Standard errors are heteroscedasticity robust and clustered at the municipality level.

Table OA-D.3: Regression results of received police staff, detailed robbery

\begin{tabular}{lcccc}
\hline \hline & $\begin{array}{c}\text { Banks/ } \\
\text { Post } \\
(1)\end{array}$ & $\begin{array}{c}\text { Patrol } \\
\text { station } \\
(2)\end{array}$ & $\begin{array}{c}\text { Drug-related } \\
\text { robbery } \\
(3)\end{array}$ & $\begin{array}{c}\text { Robbery in } \\
\text { apartments } \\
(4)\end{array}$ \\
\hline reform & -0.011 & -0.009 & 0.002 & $(0.011)$ \\
Average & $(0.029)$ & $(0.031)$ & .027 & 0.075 \\
Observations & .082 & .138 & 2,642 & $.171)$ \\
Municipalities & 2,642 & 2,642 & 244 & 2,642 \\
Average & 244 & 244 & .018 & 244 \\
\hline
\end{tabular}

Notes: The table reports difference-in-differences estimation results for detailed crime categories within robbery. The categories among robbery are robbery from banks/post stations, patrol station, drug-related robbery and robbery in apartments. The dependent variable corresponds to $(\log )$ reported crime. Standard errors are heteroscedasticity robust and clustered at the municipality level. 


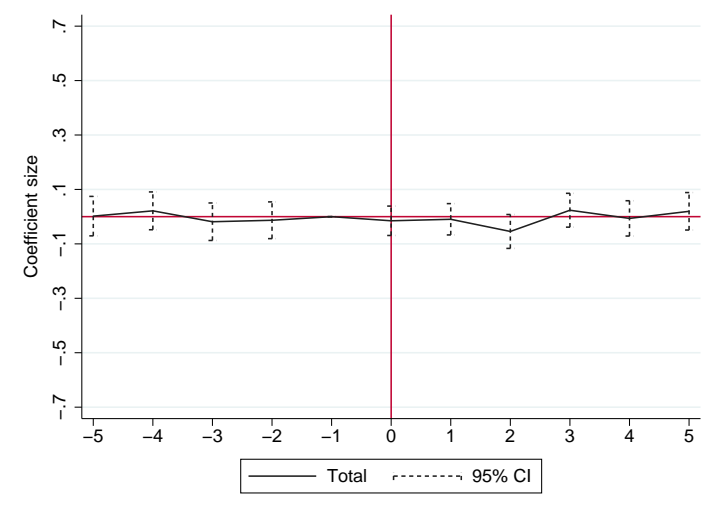

Total crime

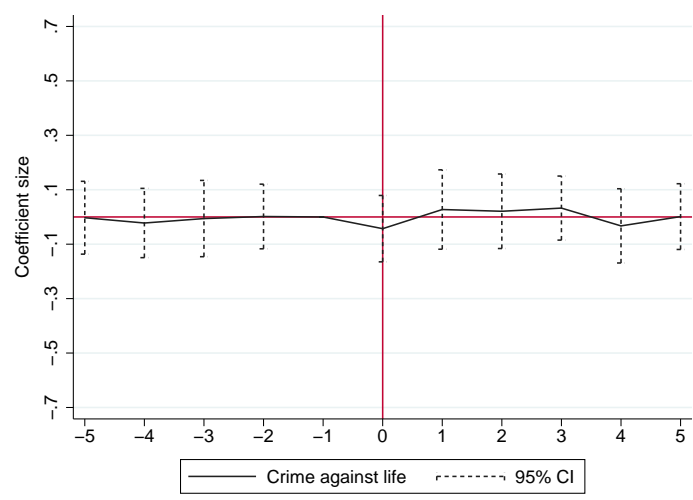

Crime against life

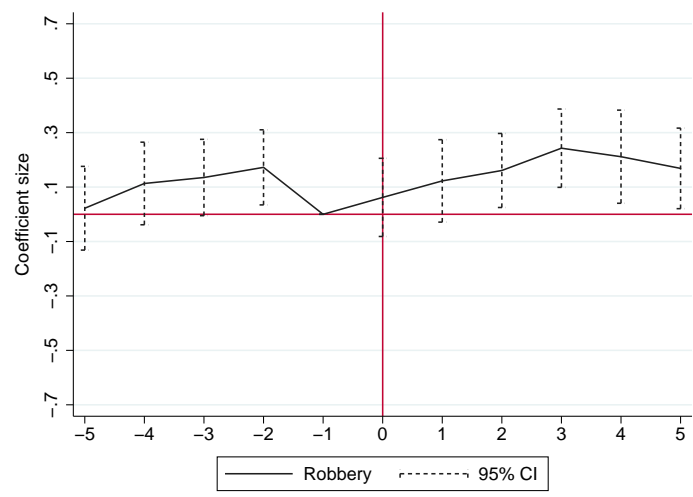

Robbery

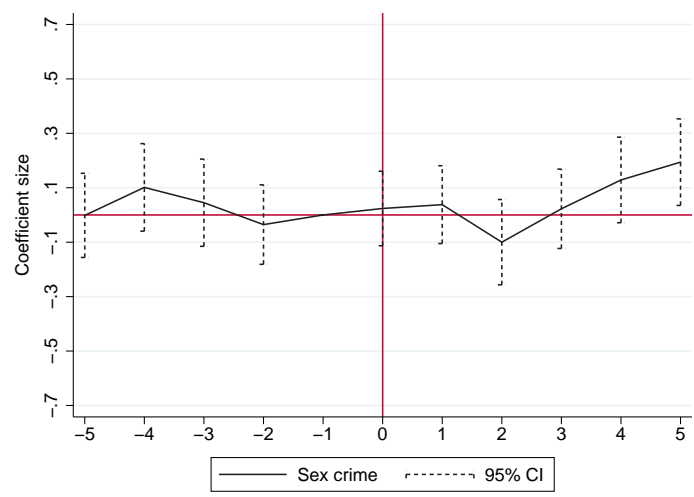

Sex crime

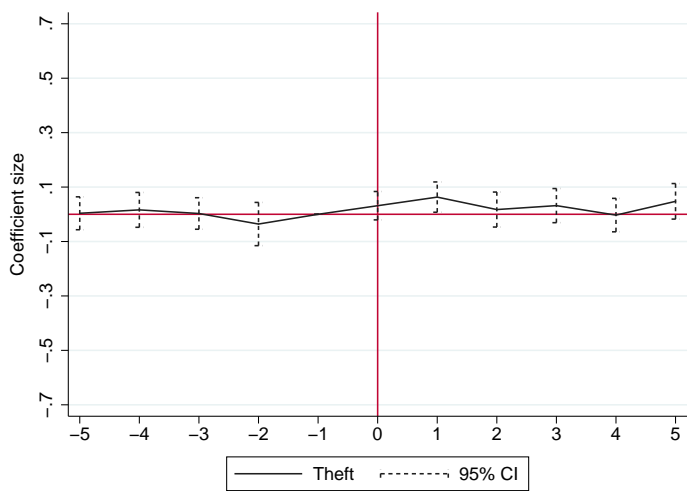

Theft

Notes: The figure reports event study estimation results on the $(\log )$ number of reported crime cases for total crime and four broad crime categories. The categories are homicide, sex crime, robbery and theft. Standard errors are heteroscedasticity robust and clustered at the municipality level. $95 \%$ confidence intervals are displayed by vertical bars.

Figure OA-D.1: Treatment effect of received police staff on broad crime categories 

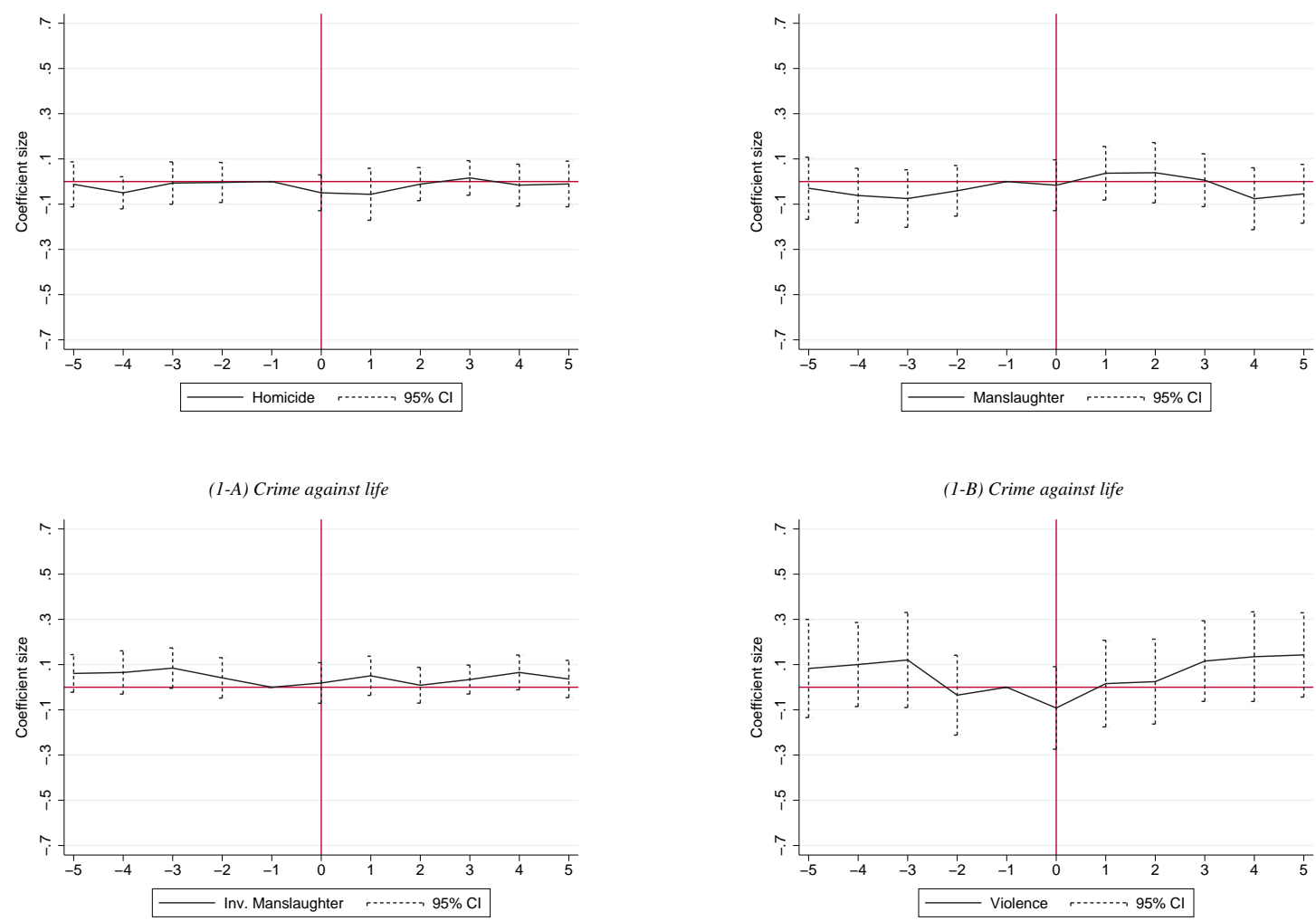

(1-C) Crime against life

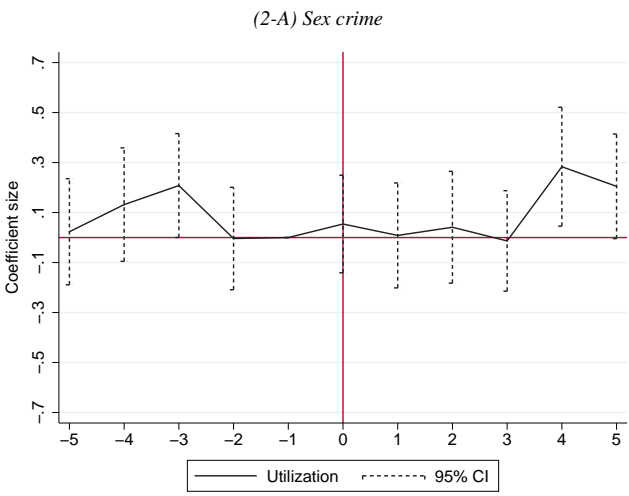

(2-B) Sex crime

(2-C) Sex crime

Notes: The figure reports event study estimation results on the (log) number of reported crime cases among detailed crime categories within crime against life and sex crime. The categories among crime against life are homicide, manslaughter and involuntary manslaughter. The categories among sex crime are sex crime including violence, sexual abuse and utilization of sexual tastes. Standard errors are heteroscedasticity robust and clustered at the municipality level. $95 \%$ confidence intervals are displayed by vertical bars.

Figure OA-D.2: Treatment effect of received police staff on body-related crime 


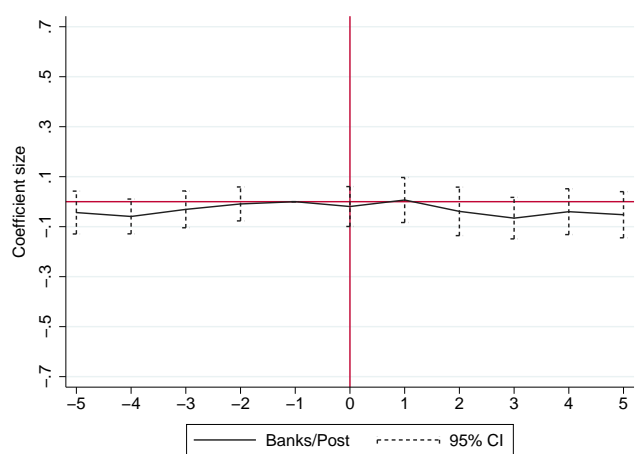

(1-A) Robbery

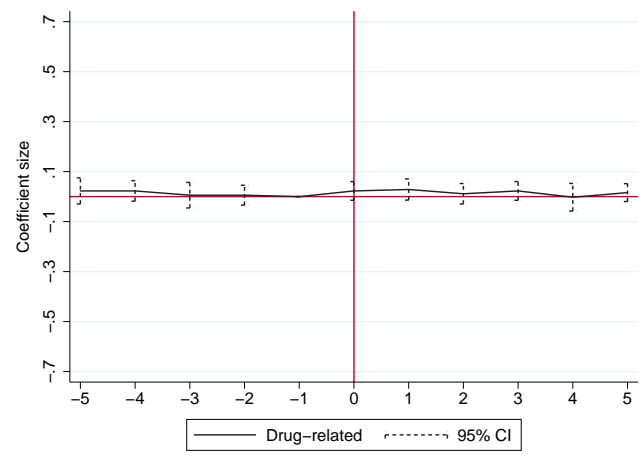

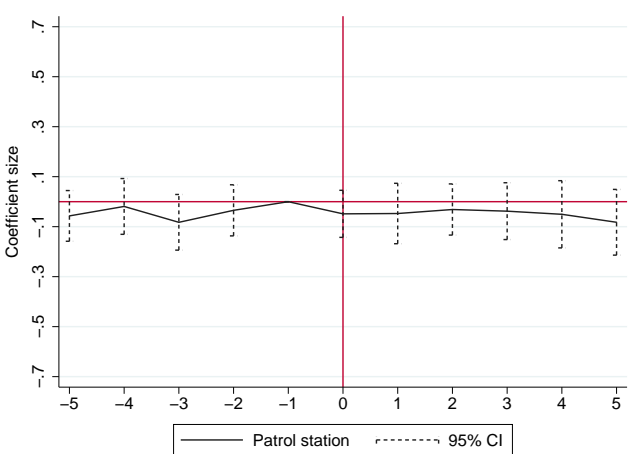

(1-B) Robbery

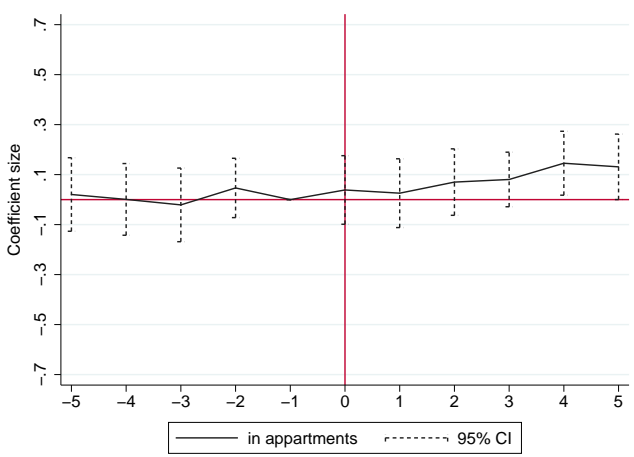

(I-D) Robbery

Notes: The figure reports event study estimation results on the $(\log )$ number of reported crime cases among detailed crime categories within robbery. The categories among robbery are robbery from banks/post stations, patrol station, drug-related robbery and robbery in apartments. Standard errors are heteroscedasticity robust and clustered at the municipality level. 95\% confidence intervals are displayed by vertical bars.

Figure OA-D.3: Treatment effect of received police staff closure on robbery 


\section{D.2 Detection rates}

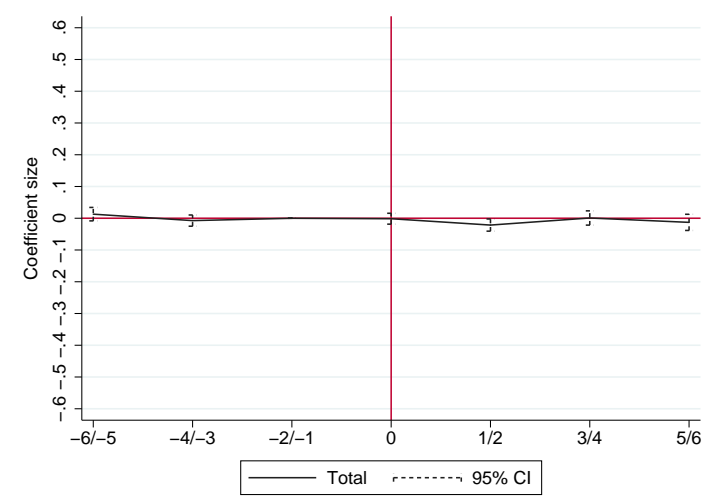

Total crime

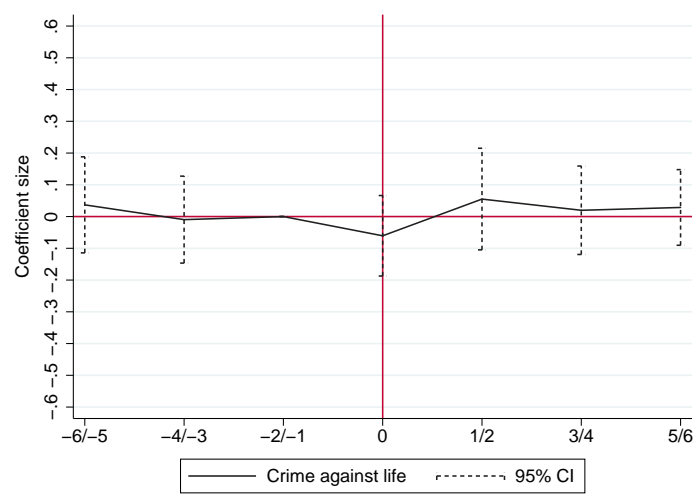

Crime against life

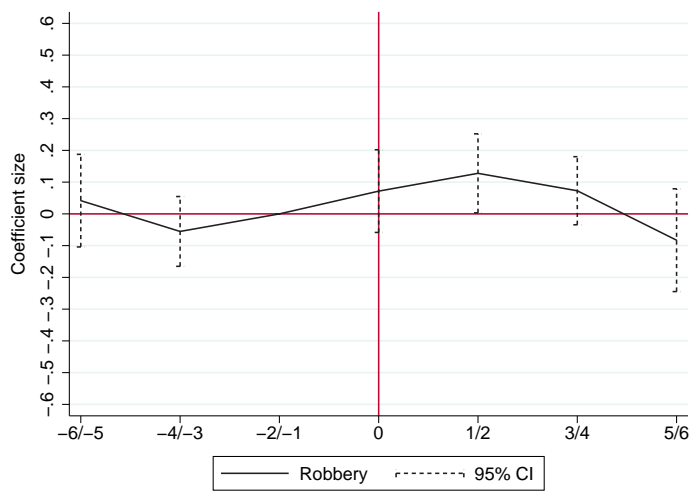

Robbery

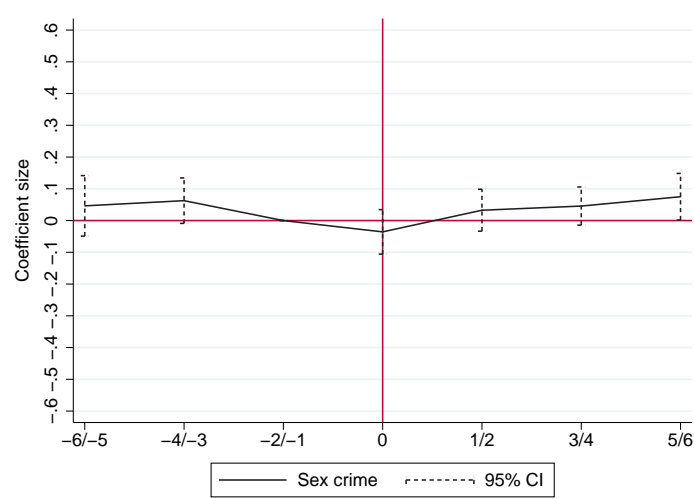

Sex crime

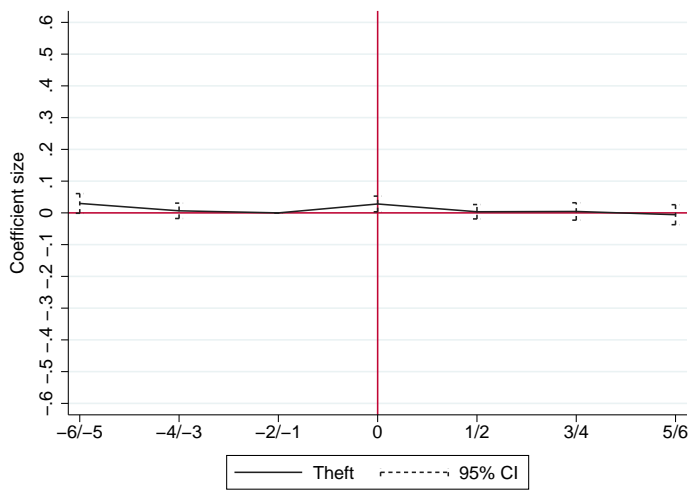

Theft

Notes: The figure reports event study estimation results on detection rates for total crime and four broad crime categories. The categories are homicide, sex crime, robbery and theft. Due to fact that estimation is conditional on positive reported crime case for municipality $i$ and time $t$, the regression model pools always two years. Standard errors are heteroscedasticity robust and clustered at the municipality level. $95 \%$ confidence intervals are displayed by vertical bars.

Figure OA-D.4: Treatment effect of received police staff on detection rates of broad crime categories 